\title{
DigitalCommons@NYLS
}

Winter 2019

\section{A World of Steel-Eyed Death: An Empirical Evaluation of the Failure of the Strickland Standard to Ensure Adequate Counsel to Defendants with Mental Disabilities Facing the Death Penalty}

Michael L. Perlin

Talia Roitberg Harmon

Sarah Chatt

Follow this and additional works at: https://digitalcommons.nyls.edu/fac_articles_chapters

Part of the Criminal Procedure Commons, Disability Law Commons, and the Law and Psychology Commons 
"A WORLD OF STEEL-EYED DEATH": AN EMPIRICAL EVALUATION OF THE FAILURE OF THE STRICKIAND

Michael L. Perlin, Esq.**

Talia Roitberg Harmon, PhD.***

Sarah Chatt, A.B.***

\section{TABLE OF CONTENTS}

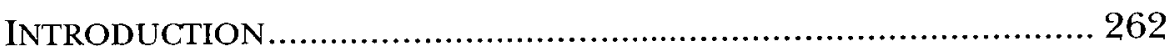

I. ADEQUACY OF COUNSEL IN DEATH PENALTY CASES............ 264

A. The Reality of Inadequacy ........................................ 264

B. The Impact of Strickland ........................................... 268

C. In the Aftermath of Strickland .................................... 272

D. Supreme Court Developments After Strickland ................. 274

II. SOME JURISPRUDENTIAL FILTERS ................................... 278

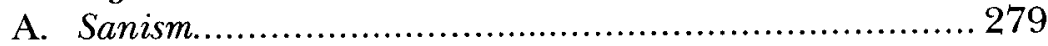

B. Pretextuality........................................................ 280

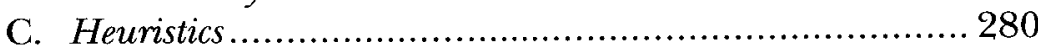

D. "Ordinary Common Sense"........................................... 281

E. In the Context of Strickland Claims ............................. 282

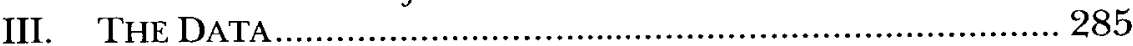

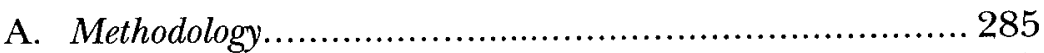

B. About Cohorts of the Cases.......................................... 287

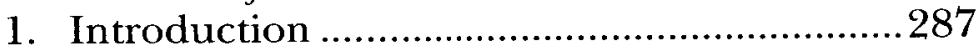

2. Reversals or Remands..................................287

3. "Back Stories"...............................................297

4. Those Affirmances with No Mitigation ...........301

C. Conclusions and Findings..................................... 304

IV. THERAPEUTIC JURISPRUDENCE ........................................... 305

A. Its Meaning.............................................................. 305

* The authors wish to thank David Dow, Bill Quigley, John Getsinger, Richard Ellis, Jeffrey Friesen, Edward Chikofsky and Prof. Robert C. Owen for their invaluable help and information. Portions of this paper were presented by one of the authors (TRH) at the American Society of Criminology meeting, November 2018, Atlanta, GA.

** Adjunct Professor of Law, Emory University School of Law. Instructor, Loyola University New Orleans, Department of Criminology and Justice. Professor Emeritus of Law, Founding Director, International Mental Disability Law Reform Project, Co-founder, Mental Disability Law and Policy Associates, New York Law School.

*** Chair and Professor, Niagara University, Department of Criminal Justice and Criminology.

**** Psy.D. student, Spaulding University. 
B. In the Context of These Cases..................................... 307

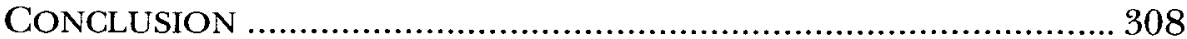

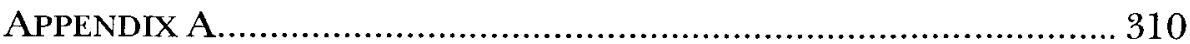

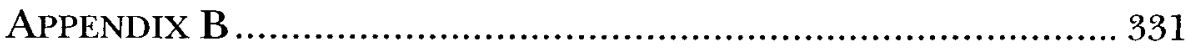

\section{INTRODUCTION}

Anyone who has been involved with death penalty litigation in the past four decades knows that one of the most scandalous aspects of that process-in many ways, the most scandalous-is the inadequacy of counsel so often provided to defendants facing execution. By now, virtually anyone with even a passing interest is well versed in the cases and stories about sleeping lawyers, missed deadlines, alcoholic and disoriented lawyers, and, more globally, lawyers who simply failed to vigorously defend their clients. ${ }^{\prime}$ This is not news.

And, in the same vein, anyone who has been so involved with this area of law and policy for the past thirty-five years knows that it is impossible to make sense of any of these developments without a deep understanding of the Supreme Court's decision in Strickland $v$. Washington, ${ }^{2}$ the case that established a pallid, virtuallyimpossible-to-fail test for adequacy of counsel in such litigation. ${ }^{3}$ Again, this is not news.

1. See, e.g., Kenneth Williams, Does Strickland Prejudice Defendants on Death Row? 43 U. RICH. L. REv. 1459, 1460 (2009); id. at 1459 n.3 (comparing Burdine v. Johnson, 262 F.3d 336, 338 (5th Cir. 2001) (finding that defendant had ineffective assistance of counsel because his lawyer slept through significant portions of his capital murder trial) with Ex parte McFarland, 163 S.W.3d 743, 748-49 (Tex. Crim. App. 2005) (finding no ineffective assistance even though lead counsel slept through nearly entire trial)); see generally MICHAEL L. PERLIN, Mental Disability and the Death Penalty: The Shame of the States 131-34 (2013) (discussing cases).

2. 466 U.S. 668 (1984).

3. One of the authors (MLP) has been writing about this for twenty-five years. See Michael L. Perlin, The Sanist Lives of Jurors in Death Penalty Cases: The Puzzling Role of Mitigating Mental Disability Evidence, 8 NOtRe Dame J.L. Ethics \& Pub. POl.'Y. 239 (1994) [hereinafter Perlin, Sanist Lives]; Michael L. Perlin, "The Executioner's Face Is Always Well-Hidden": The Role of Counsel and the Conerts in Delermining Who Dies, 41 N.Y. L. SCH. L. REV. 201, 205-06 (1996) [hereinafter Perlin, Executioner's Face] (footnotes omitted) ("Since 1983, when the Supreme Court established a pallid, nearly-impossible-to-violate, adequacy standard in Strickland $\boldsymbol{v}$. Washington (requiring simply that counsel's efforts be "reasonable" under the circumstances), courts have become less and less interested in the question at hand, and little evidence disputes the failure of Strickland to insure that capital defendants truly receive adequate assistance of counsel."). 
We also know that some of the most troubling results in Strickland interpretations have come in cases in which the defendant was mentally disabled-either by serious mental illness or by intellectual disability. ${ }^{4}$ Some of the decisions in these cases-rejecting Strickland-based appeals - have been shocking, and "make a mockery out of the notion of a constitutionally based standard." By way of example, the undisputed evidence is that, with regards to matters of mitigation, "missed mental health claims" made up about one-third of an earlier cohort of cases studied. ${ }^{7}$

But, to the best of our knowledge, no one has-prior to this Article-undertaken an extensive empirical analysis of how one discrete U.S. federal circuit court of appeals has dealt with a wide array of Strickland-claim cases in cases involving defendants with mental disabilities. ${ }^{8}$ We do this here. In this Article, we reexamine these issues from the perspective of the 198 cases decided in the Fifth Circuit from 1984 to 2017 involving death penalty verdicts in state prosecutions in which, at some stage of the appellate process, a Strickland claim was made. ${ }^{9}$ As we demonstrate subsequently, Strickland is indeed a pallid standard, fostering "tolerance of abysmal lawyering," 10 and is one that makes a mockery of the most vital of constitutional law protections: the right to adequate counsel. ${ }^{11}$

This Article will proceed in this way. First, we discuss the background of the development of counsel adequacy in death penalty cases. Next, we look carefully at Strickland, and the subsequent Supreme Court cases that appear-on the surface-to bolster it in this context. We then consider multiple jurisprudential filters that

4. Interestingly, this latter cohort includes cases that have been of great interest to the Supreme Court in the past seventeen years. See, e.g., Atkins v. Virginia, 536 U.S. 304 (2002), Hall v. Florida, 134 S. Ct. 1986 (2014), and Moore v. Texas, 137 S. Ct. 1039 (2017), all discussed in Michael L. Perlin \& Heather Ellis Cucolo, mental Disability law: Civil and CRIMINAL ( $3 \mathrm{~d}$ ed. 2018), $\$ \S 17-42.2$ to $17-4-2.4$, at $17-85$ to $17-119$ (discussing cases), and Moore v. Texas, $139 \mathrm{~S}$. Ct. 666 (2019), discussed in $i d$. $\$ 17-4.2 .5$, at 17-127 to 17-128 (3d ed. 2019).

5. PERLIN, supra note 1 , at 132.

6. See infra part III.B.

7. See Leona D. Jochnowitz, Missed or Foregone Mitigation: Analyzing Claimed Error in Missouri Capilal Clemency Cases, 46 CRIM. L. BULL., 347, 375 (2010).

8. For a listing of all Sirickland cases prior to 1988, see Martin Calhoun, How to Thread the Needle: Toward a Checklist-Based Standard for Evaluating Ineffective Assistance of Counsel Claims, 77 GEO. L.J. 413, 458, Appendix I (1988) (finding that ineffective assistance was found in fewer than $5 \%$ of that cohort of cases).

9. See infra part III. A, explaining the research methodology.

10. William S. Geimer, A Decade of Strickland's Tin Horm: Doctrinal and Practical Undermining of the Right to Counsel, 4 WM. \& MARY BiLL RTS. J. 91,94 (1995).

11. We use the word "mockery" consciously. Prior to Strickland, the test for adequacy of counsel in many circuits was whether the trial was a "farce and a mockery of justice." Diggs v. Welch, 148 F.2d 667, 670 (D.C. Cir. 1945). Under that test, convictions would be overturned only if counsel's performance was "so ineffective as to shock the conscience of the court." United States v. Steed, 465 F.2d 1310, 1317 (9th Cir. 1972). 
we believe must be taken seriously if this area of the law is to be given any authentic meaning. Next, we will examine and interpret the data that we have developed. Finally, we will look at this entire area of law through the filter of therapeutic jurisprudence, and then explain why and how the charade of "adequacy of counsel law" fails miserably to meet the standards of this important school of thought.

Our title comes, in part, from Bob Dylan's song, Shelter from the Storm. ${ }^{12}$ As one of the authors (MLP) has previously noted in another article drawing on that song's lyrics, "[i]n a full-length book about that album, the critics Andy Gill and Kevin Odegard characterize the song as depicting a "mythic image of torment." ${ }^{13}$ The defendants in the cases we write about-by and large, defendants with profound mental disabilities who face the death penalty in large part because of the inadequacy of their legal representation-confront (and are defeated by) a world of 'steel-eyed death.' We hope that this Article helps change these realities.

\section{Adequacy of Counsel in Death Penalty Cases ${ }^{14}$}

\section{A. The Reality of Inadequacy}

If one looks at a range of death penalty cases that have been litigated in the forty-plus years since the United States Supreme Court's holding in Gregg v. Georgia ${ }^{15}$ that the death penalty was not necessarily a violation of the Eighth Amendment's ban on cruel and unusual punishment, one undeniable truth emerges: in so many of these cases, the most critical issue in determining whether a defendant lives or dies is the quality of counsel. ${ }^{16}$ Stephen Bright, one of the great death penalty lawyers, has said flatly that "the death penalty will too often be punishment not for committing the

12. Bob Dylan, Shelter From THE STORM (Columbia Records 1975).

13. Michael L. Perlin \& Henry A. Dlugacz, "It's Doom Alone That Counts": Can International Human Rights Law Be an Effective Source of Rights in Correctional Conditions Litigation? 27 Beilav. SCI. \& L. 675, 677 (2009) (quoting ANDY Gill \& Kevin Odegard, A SimPLe Twist OF FATE: Bob DYlan AND THE MAKING Of BloOD ON THE TRACKS 163 (2004)); see also Michael L. Perlin, 'I'll Give You Shelter from the Storm': Privilege, Confidentiality, and Confessions of Crime, 29 LOY. L.A. L. REV. 1699 (1996).

14. See generally PERLIN, supra note 1, at 123-38, from which portions of this section are adapted.

15. 428 U.S. 153 (1976).

16. See State v. Morton, 715 A.2d 228, 277 (N.J. 1998) (Handler, J., dissenting in part) (quoting Perlin, Executioner's Face, supra note 3, at 202). 
worst crime, but for being assigned the worst lawyer." ${ }^{17}$ By way of example, a recent comprehensive study of the operation of the death penalty in Tennessee found a reversal rate of $23 \%$ based on inadequate representation, truly a jaw-dropping figure. ${ }^{18}$

In death penalty cases, attorneys-who are frequently criminally underfunded ${ }^{19}$ - must search for a way to develop an authentic relationship with and "humanize" their client, ${ }^{20}$ typically one who is the target of public and media animosity. ${ }^{21}$ They must investigate for mitigating evidence, obtain expert defense witnesses, investigate to rebut aggravating evidence, and attempt to negotiate a plea bargain where appropriate. ${ }^{22}$ If there is a guilty verdict, they must be prepared to make informed strategic decisions about the penalty phase. $^{23}$ No one has seriously contradicted Professor Welsh White's statement that "[t] he single greatest problem with our system of capital punishment is the quality of representation afforded capital defendants," ${ }^{24}$ nor has anyone seriously questioned the accuracy of Justice Ruth Bader Ginsburg's observation: "I have yet to see a death case among the dozens coming to the Supreme Court on eve-of-execution stay applications in which the defendant was well represented at trial." 25

The inadequacy of trial and appellate lawyers for capital defendants has been widely recognized as the "single most spectacular failure in the administration of capital punishment." ${ }^{26}$ There are

17. Stephen Bright, Dealh by Lollery-Procedural Bar of Constitutional Claims in Capilal Cases Due to Inadequate Representation of Indigent Defendants, 92 W. VA. L. REV. 679, 695 (1990); see also Williams, supra note 1 , at 1459 ("Whether one ends up on death row is usually determined not by the heinousness of the crime, but by the quality of trial counsel.").

18. Bradley A. MacLean \& H.E. Miller, Jr., Tennessee's Dealh Penalty Lottery, 13 TENN.J. L. \& POL'Y 85, 146 (2018).

19. Pun intended. See, e.g., Wiles v. Bagley, 561 F.3d 636, 645 n. 15 (6th Cir. 2009) (quoting ABA MORATORIUM Implementation Projecr, State Death Penalty ASSESSMENTS: KEY FINDINGS (2007) ("The compensation paid to appointed capital defense attorneys is often woefully inadequate, dipping to well under $\$ 50$ per hour in some cases.")).

20. Welsh S. White, Effective Assistance of Counsel in Capilal Cases: The Evolving Standard of Care, 1993 U. ILL. L. REV. 323, 338, 361 (1993).

21. See id. at $340-41$.

22. Id. at $342-43$.

23. See generally James M. Doyle, The Lauyers' Ant: "Representation" in Capilal Cases, 8 YALE J.L. \& HUMAN. 417 (1996) (discussing the importance of shaping a client's image).

24. White, supra note 20 , at 376 (emphasis added).

25. Justice Backs Death Penally Freeze, CBS News (April 10, 2001), https://www.cbsnews.com/news/justice-backs-death-penalty-freeze/.

26. Note, The Eighth Amendment and Ineffective Assistance of Counsel in Capital Trials, 107 HARV. L. REV. 1923, 1923 (1994); see also, e.g., Ira Robbins, Toward a More Just and Effective System of Reviezu in State Dealh Penalty Cases, 40 AM. U. L. REv. 1, 16 (1990) ("Specifically, the lack and inadequacy of counsel in state capital proceedings forces state and federal postconviction judges to: adjudicate cases on the basis of incomplete and often incomprehensible records; resolve manifold colorable claims of ineffective assistance of counsel; dispose of myriad procedural questions-including exhaustion of state remedies, procedural default, and successive petition issues-arising from the failure of counsel to notice and assert meri- 
many reasons for this, including, importantly, funding systems that discourage experienced and competent criminal attorneys from taking appointments in death penalty cases and prevent even the most talented attorneys from preparing an adequate defense, particularly for the penalty phase.

Capital defendants are often represented by "the bottom of the bar. ${ }^{28}$ An American Bar Association (ABA) Report on the representation of Georgia defendants facing the death penalty thus concluded:

[The state's] recent experience with capital punishment has been marred by examples of inadequate representation ranging from virtually no representation at all by counsel, to representation by inexperienced counsel, to failures to investigate basic threshold questions, to lack of knowledge of governing law, to lack of advocacy on the issue of guilt, to failure to present a case for life at the penalty phase. ${ }^{29}$

The situation is worse-far worse-for defendants with mental disabilities. Forty years ago, when surveying the availability of counsel to mentally disabled litigants, President Carter's Commission on Mental Health noted the frequently substandard level of representation made available to mentally disabled criminal defendants. ${ }^{30}$ Little that has happened in the intervening decades has been a palliative for this problem. As Mental Health America

torious claims for relief; and grant constitutionally mandated relief and costly retrials in numerous cases.").

27. See Commonwealth v. McGarrell, 87 A. 3d 809, 811 (Pa. 2014) (McCaffery, J., dissenting) (writing separately "to explain why, in my view, the continued oversight of this Court is necessary with respect to the reform measures undertaken to remedy Philadelphia's heretofore chronic underfunding for legal services for indigent capital defendants ...."); Douglas W. Vick, Poorhouse Justice: Underfunded Indigenl Defense Services and Arbitrary Dealh Senlences, 43 BUFF. L. REV. 329, 397-98 (1995).

28. Stephanie Saul, When Death Is the Penalty: Attomeys for Poor Defendants Often Lack Experience and Skill, N.Y. NewSDAY, Nov. 25, 1991, at 8. As of the late 1980's/early 1990's, ten percent of death row prisoners in Alabama were represented by trial lawyers subsequently disbarred or disciplined. Marcia Coyle et al., Fatal Defense: Trial and Error in the Nation's Death Belt, NAT'L L.J., June 11, 1990, at 30. Almost thirteen percent of such inmates in Louisiana were represented by similar counsel. Id. Almost twenty-five percent of Kentucky's death row inmates were represented by lawyers since disbarred or suspended. Saul, supra at 8 . An appointed counsel in a death case told the press, "I despise [being appointed], I'd rather take a whipping ...." Coleman v. Kemp, 778 F.2d 1487, 1522 (11th Cir. 1985). One rationale for this phenomenon is that judges subject to reelection who must appear tough on crime may purposely appoint defense counsel of low quality. Panel Discussion, The Dealt of Fairmess? Counsel Competency and Due Process in Death Penalty Cases, 31 HOUS. L. REV. 1105, 1198 (1994).

29. Robbins, supra note 26, at 66 (citations omitted).

30. Cf. Mental Health and Ituman Rights: Report of the Task Panel on Legal and Ethical Issues, 20 ARIZ. L. REV. 49, 62 (1978) (noting that few public defender offices or other legal services organizations provide special expertise in this area). 
(formerly, the National Mental Health Association) has observed, "[t]he process of determining guilt and imposing sentence is necessarily more complex for individuals with mental health conditions. A high standard of care is essential with regard to legal representation as well as psychological and psychiatric evaluation for individuals with mental health conditions involved in death penalty cases." ${ }^{31}$

There is no question that, in a death penalty case, representing a defendant with a mental disability is 'harder' than representing other defendants. Consider the Commentary to the ABA Guidelines for the Appointment and Performance of Defense Counsel in Death Penalty Cases, focusing on the special problems related to the issue of trust ${ }^{32}$ in the representation of the defendant with a mental disability or from a different cultural background $d^{33}$ than the lawyer:

Many capital defendants are ... severely impaired in ways that make effective communication difficult: they may have mental illnesses or personality disorders that make them highly distrustful or impair their reasoning and perception of reality; they may be mentally retarded or have other cognitive impairments that affect their judgment and understanding; they may be depressed and even suicidal; or they may be in complete denial in the face of overwhelming evidence. In fact, the prevalence of mental illness and impaired reasoning is so high in the capital defendant population that " $[\mathrm{i}] \mathrm{t}$ must be assumed that the client is emotionally and intellectually impaired." There will also often be significant cultural and/or language barriers between the client and his lawyers. In many cases, a mitigation specialist, social worker or other mental health expert can

31. Position Statement 54: Death Penalty and People with Mental Illnesses, Mental Health AMERICA, https://www.mhanational.org/issues/position-statement-54-death-penalty-andpeople-mental-illnesses (last visited Dec. 1, 2019); see also, e.g., Amy Greenbaum, The Death Penalty: Mentally Ill Men Are Execuled; Mentally Ill Women Are Committed, 42 T. Marshall L. REV. ONLINE 1, 10 (2016) ("Key players in the criminal justice system have deluded themselves in believing that they know mental illness when they see it, a misconception that carries lethal consequences for the mentally ill capital defendant.").

32. See, e.g., Easton v. Wilson, 2014 WL 6622512, at 22 (D. Wyo. 2014) ("Counsel at all stages of the case should make every appropriate effort to establish a relationship of trust with the client.") (quoting ABA GUIDELINES FOR THE APPOINTMENT AND PERFORMANCE OF Defense Counsel in Death Penalty Cases 10.5(A) (Feb. 2003)).

33. See Supplemenlary Guidelines for the Mitigation Function of Defense Teams in Dealh Penally Cases, 36 HOFSTRA L. REV. 677, 682-83 (2008) (emphasizing the importance of the mitigation specialist's role in assisting defense counsel to overcome the obstacles to communicating with the client presented by the client's mental health problems or social and cultural backgrounds). 
help identify and overcome these barriers, and assist counsel in establishing a rapport with the client. ${ }^{34}$

Evidence reveals the enormity of this problem. A review of eighty death sentences issued in four "death belt states" (Georgia, Mississippi, Alabama and Virginia) between 1997 and 2004 found that "[i]n 73 of the 80 cases, defense lawyers gave jurors little or no evidence to help them decide whether the accused should live or die. The lawyers routinely missed myriad issues of abuse and mental deficiency, abject poverty and serious psychological problems." ${ }^{35}$ John Blume and Pamela Blume Leonard have made the significance of these errors-and their potentially fatal outcome-crystalclear:

To address mental health issues competently and effectively, defense counsel must understand the wide range of mental health issues relevant to criminal cases, recognize and identify the multitude of symptoms that may be exhibited by our clients, and be familiar with how mental health experts arrive at diagnoses and determine how the client's mental illness influenced his behavior at the time of the offense. Without this knowledge, it is impossible to advocate effectively for a mentally ill client or to overcome jurors' cynicism about mental health issues. We believe juror skepticism often reflects inadequate development and ineffective presentation rather than a biased refusal to appreciate the tragic consequences of mental illness. ${ }^{36}$

\section{B. The Impact of Strickland}

Since 1983, when the Supreme Court decided Strickland (requiring simply that counsel's efforts be "reasonable" under the circumstances), ${ }^{37}$ courts have become less and less interested in the question at hand, and little evidence disputes the failure of Strickland to ensure that capital defendants truly receive adequate assistance of counsel. $^{38}$

\footnotetext{
34. American Bar Association, Guidelines for the Appointment and Performance of Defense Counsel in Death Penally Cases, 31 HOFSTRA L. REv. 913, $1007-08$ (2003) (citations omitted).

35. Sanjay K. Chhablani, Chronically Stricken: A Continuing Legacy of Ineffective Assistance of Counsel, 28 ST. LOUIS U. PUB. L. REV. 351, 363 (2009) (citations omitted).

36. John Blume \& Pamela Blume Leonard, Capilal Cases, CHAMPION, November 2000, at 63 .

37. Strickland v. Washington, 466 U.S. 668, 669 (1984).

38. PERLIN \& CuCOLO, supra note $4, \$ 17-3.6$, at 17-32 to 17-44.
} 
The test for an ineffectiveness claim in Strickland is "whether counsel's conduct so undermined the proper function of the adversarial process that the trial court cannot be relied on as having produced a just result." ${ }^{39}$ To determine whether counsel's assistance was "so defective as to require reversal," lished a two-part test:

First, the defendant must show that counsel's performance was deficient. This requires showing that counsel made errors so serious that counsel was not functioning as the "counsel" guaranteed the defendant by the Sixth Amendment. Second, the defendant must show that the deficient performance prejudiced the defense. This requires showing that counsel's errors were so serious as to deprive the defendant of a fair trial, a trial whose result is reliable. Unless a defendant makes both showings, it cannot be said that the conviction or death sentence resulted from a breakdown in the adversary process that renders the result unreliable. ${ }^{41}$

The Court concluded that the new "objective," "reasonably effective assistance" standard need be measured by "simply reasonableness under prevailing professional norms." ${ }^{\text {42 }}$ Here, the Court would "indulge a strong presumption that counsel's conduct falls within the wide range of reasonable professional assistance." ${ }^{43}$

In the case before it, the Court found that there was a duty for counsel to "make reasonable investigations or to make a reasonable decision that makes particular investigations unnecessary." ${ }^{44}$ But, even a "professionally unreasonable" ${ }^{45}$ error will not result in reversal if such error "had no effect on the judgment." ${ }^{46}$ To prevail, a defendant must show prejudice, as measured by a showing of "a reasonable probability that, but for counsel's unprofessional errors, the result ... would have been different."

\footnotetext{
39. Sirickland, 466 U.S. at 686 .

40. Id. at 687 .

41. Id.

42. Id. at $687-88$.

43. Id. at 689 .

44. Id. at 691 .

45. Id.

46. Id.

47. Id. at 694 . Applying these principles to the case before the Court was "not difficult." $I d$. at 698 . It found that respondent's trial counsel's conduct "cannot be found unreasonable," and that, even assuming unreasonableness, "respondent suffered insufficient prejudice to warrant setting aside his death sentence." Id. at 698-99. The Court characterized trial counsel as having made a "strategic choice," with nothing in the record showing that his "sense of hopelessness distorted his professional judgment, and the decision not to seek
} 
Justice Marshall sharply dissented, ${ }^{48}$ critiquing the majority's adoption of a performance standard "that is so malleable that, in practice, it will either have no grip at all or will yield excessive variation in the manner in which the Sixth Amendment is interpreted." ${ }^{49}$ By this vagueness, he concluded, the Court has "not only abdicated its own responsibility to interpret the Constitution, but also impaired the ability of the lower courts to exercise theirs." ${ }^{50}$

Individual post-Strickland cases are striking and, by any metric, bizarre. $^{51}$ In one case, counsel was found to be effective even though he had failed to introduce ballistics evidence showing that the gun taken from the defendant was not the murder weapon. ${ }^{52}$ In another, an attorney was found constitutionally adequate to provide representation to a death-eligible defendant notwithstanding the fact that he had been admitted to the bar for only six months and had never tried a jury case.$^{53}$ Another lawyer was found constitutionally adequate even where during the middle of the trial he appeared in court intoxicated and spent a night in jail. ${ }^{51}$ There is little evidence to contradict Welsh White's conclusion that "[1] ower courts' application of Strickland has produced some appalling results." ${ }^{55}$

more character or psychological evidence than was already in hand was likewise reasonable." $I d$. at 699 . In short, "[f]ailure to make the required showing of either deficient performance or sufficient prejudice defeats the ineffectiveness of the claim." Id. at 700. Generally, beyond the scope of this Article, is the question of how prejudice is to be accurately assessed in such cases. See infra note 135 on the question of prejudice in Sirickland cases in the context of violations of Ake v. Oklahoma, 470 U.S. 68 (1985) ("More generally," the Court concluded, "respondent has made no showing that the justice of his sentence was rendered unreliable by a breakdown in the adversary process caused by deficiencies in counsel's assistance," thus, "the sentencing proceeding was not fundamentally unfair."); see also MICHAEL L. PERLIN, THE JURISPRUDENCE OF THE INSANITY DEFENSE 148-54 (1995).

48. Sirickland, 466 U.S. at 706.

49. Id. at 707

50. Id. at 708. Justice Marshall characterized the standard as suffering from a "debilitating ambiguity," which will likely "stunt the development of Constitutional doctrine in this area." Id. at 708-09. Justice Brennan filed a separate opinion, concurring in part and dissenting in part. $I d$. at 701 .

51. This array of cases does not focus on the mental health issues that are at the heart of this paper.

52. Graham v. Collins, 829 F. Supp. 204, 209 (S.D. Tex. 1993).

53. Paradis v. Arave, 954 F.2d 1483, 1490-92 (9th Cir. 1992).

54. Haney v. State, 603 So. 2d 368, 377-78 (Ala. Crim. App. 1991). Of course, preStrickland cases were also appalling. In one, defense counsel was not even aware that separate sentencing proceedings were to be held in death penalty cases. See Young v. Zant, 677 F.2d 792, 797 (11th Cir. 1982).

55. Welsh S. White, Capilal Punishment's Future, 91 MiCH. L. REv. 1429, 1436 (1993) (reviewing Raymond Paternoster, Capital Punishment in America (1991)). For other examples see Stephen Bright, The Death Penalty as the Answer to Crime: Costly, Counterproductive, and Cormupting, 31 SANTA ClaRA L. REv. 1068, 1078-84 (1996) and Christine Wisermen, Representing the Condemned: A Critique of Capital Punishment, 79 MARQ. L. REV. 731, 742-44 (1996). See also Meredith J. Duncan, The (So-Called) Liability of Criminal Defense Atlomeys: $\Lambda$ System in Need of Reform, 2002 B.Y.U.L. REv. 1, 18-20 (2002) (noting that “[t]he unfortunate aftermath 
It became clear to all who were listening that Strickland was, operationally, a disaster. The chairperson of the Competency Committee of the ABA Section on Criminal Justice called it "unfortunate and misguided," charging it "failed to meet its obligation to help ensure that criminal defendants receive competent representation," concluding that it was drafted "to ensure that the review test will produce the same results as the old 'farce and mockerydue process' test." ${ }^{57}$ Self-evidently, the test's application to the facts of the case before the court in Strickland "underscores this return to the status quo ante." As the late William Genego despairingly concluded, Strickland was "a clear signal that [the Supreme Court] is not at all disturbed with inadequate performance by criminal defense lawyers," 59 and supported the conclusion that "the problem

of Strickland is that a criminally accused's right to the effective assistance of counsel does not have much substance to it at all" and that "even though the Court professed to fashion a test that would lead to the just review of ineffective assistance of counsel claims, it is doubtful whether ineffective assistance of counsel claims are currently justly reviewed."). The Supreme Court also construed Strickland narrowly in other contexts. See, e.g., Smith v. Spisak, 558 U.S. 139 (2010) (defendant not prejudiced by inadequate closing argument at penalty phase).

56. William J. Genego, The Fulure of Effective Assistance of Counsel: Performance Standards and Competent Refresentation, 22 AM. CRIM. L. REV. 181, 182 (1984).

57. Id. at 196. For a comprehensive set of specific performance standards embodying an "efficient and functional assistance test," see Barbara J. Buba, Comment, The Standard for Effective Assistance of Counsel in Pennsylvania-An Ineffective Method of Ensuring Competent Defense Represenlation, 89 DiCKINSON L. REV. 41, 69-71 (1985). For excellent early reviews of all relevant issues, see Jeffrey Kirchmeier, Drink, Drugs, and Drowusiness: The Constitutional Right to Ef fective Assistance of Connsel and the Sirickland Prejudice Requirement, 75 NEB. L. REv. 425 (1996); Richard Klein, The Relationship of the Courl and Defense Counsel: The Impact of Competent Representation and Proposals for Reform, 29 B.C. L. REv. 531 (1988); Melody Martin, Defending the Mentally III Client in Criminal Matters: Ethics, Advocacy, and Responsibility, 52 U. TORONTO FAC. L. REV, 73 (1993); Geimer, supra note 10. For later considerations of Strickland, see, e.g., Eve Brensike Primus, Structural Reform in Criminal Defense: Relocating Ineffective Assistance of Counsel Claims, 92 CoRnEll L. Rev. 679 (2007); Robert R. Rigg, The T-Rex Without Teeth: Evolving Strickland $v$. Washington and the Test for Ineffective Assistance of Counsel, 35 PEPP. L. REV. 77 (2007). The "farce and mockery" test was this: "A lack of effective assistance of counsel must be of such a kind as to shock the conscience of the Court and make the proceedings a farce and mockery of justice." United States v. Wight, 176 F.2d 376, 379 (2d Cir. 1949), cert. denied, 338 U.S. 950 (1950).

58. PERLIN, supra note 47, at 16 (citing Genego, supra note 56, at 196-98, 209-11); see also Susan K. VanBuren, Note, The Ineffective Assistance of Counsel Quandary: The Debate Continues, 18 AKRON L. REV. 325, 334 (1984) (Strickland's seemingly "objective" test is "poisoned with obtrusive subjectivity."); Jonathan E. Fink, Note, Constitutional Law-Sixth Amendment Guarantees Assistance of Connsel That Is Reasonably Effective and Does Not Prejudice the Faimess of the Proceeding, 14 U. BALT. L. REV. 335, 344, 345 (1985) (Strickland Court's analysis of ineffective counsel claims "self-defeating"; case's result "very well may be the expeditious disposal, if not the outright discouragement, of ineffective assistance allegations, rather than the protection of the fundamental fairness of the proceedings in such claims."). But cf. State v. Nash, 694 P.2d 222, 228 (Ariz. 1985) (adopting Slrickland because its "objective standard provides better guidance to lawyers and judges" than would a "more subjective" test).

59. Genego, supra note 56, at 202. 
of competency, at least in criminal cases, should be taken off the agenda." ${ }^{\prime 0}$

\section{In the Aftermath of Strickland}

An examination of an array of reported post-Strickland decisions involving findings of deficiency in death penalty cases in which defendants' history of serious mental disability was ignored by counsel clearly calls into question one of the core assumptions of the Strickland case: that counsel does exercise substantial professional judgment in providing representation. ${ }^{61}$ This is especially critical in cases where counsel completely "misses" what might be seen as mitigating evidence. ${ }^{62}$ Consider the level of lawyer-incompetence in those cases in which counsel was found to be deficient: ${ }^{63}$

- where counsel failed to discover reports from a psychologist that found defendant might have been incompetent to stand trial due to possible brain damage and head injuries; ${ }^{64}$

- where counsel failed to investigate defendant's social or mental health background, and failed to find reports determining defendant to be mentally retarded, and disclosing defendant's diagnosis of paranoid schizophrenia; ${ }^{65}$

- where counsel failed to give an expert witness documentation about defendant's mental illness and evidence of defendant's conduct at the time of the crime ${ }^{66}$ or

60. Id:; see also Peter Tague, The Attempt to Improve Criminal Defense Representation, 15 AM. CRIM. L. REV. 109, 165 (1977) (concluding, pre-Strickland, that "[u]nless courts are willing to police the attorney, they should candidly admit that the call for 'effective representation' is simply rhetoric.")

61. See Carissa Byrne Hessick, Ineffective Assistance at Sentencing, 50 B.C. L. REV. 1069, 1076 (2009) (Strickland is "a shield for counsel's behavior against judicial scrutiny.").

62. See Leona D. Jochnowitz, Missed Mitigation: Counsel's Evolving Duly to Assess and Present Mitigation at Dealh Penally Sentencing, 43 CRIM. L. BULL. 3 (2007); Jochnowitz, supra note 7.

63. These cases are discussed in PERLIN, supra note 1, at 131-32.

64. Douglas v. Woodford, 316 F.3d 1079 (9th Cir. 2003); see also Sara R. Faber, Competency, Counsel, and Criminal Defendants' Inability to Participate, 67 DUKE L.J. 1219 (2018); Sarah Gerwig-Moore, On Compelence: (Re)considering Appropriale Legal Slandards for Examining Sixth Amendment Claims Related to Criminal Defendants' Mental Illness and Disalility, 84 TENN. L. REV. 971, 979-80 (2017) (on Slrickland in incompetency cases); PERLIN \& CuCOLO, supra note 4, $\$$ 13-1.5.4.

65. Summerlin v. Schriro, 427 F.3d 623 (9th Gir. 2005),

66. Hovey v. Ayers, 458 F.3d 892 (9th Cir. 2006). 
- where counsel failed to read the record of defendant's prior trials and thus failed to learn that defendant potentially suffered from brain damage (and then when made aware, failed to consult a neurologist), and failed to sufficiently investigate defendant's background so as to learn of his very low IQ scores. ${ }^{67}$

But, as we explore in depth in Part III, these examples in no way should be taken as evidence that Strickland is an effective palliative for the problems at hand. Interpretative cases in both federal and state courts have been wildly inconsistent. ${ }^{68}$ The vast majority of appellate cases-both the ones we study in this paper and those discussed elsewhere ${ }^{69}$-have affirmed convictions or the denial of habeas writs, concluding that counsel's performance was adequate under the Strickland $v$. Washington standard. ${ }^{70}$ Consideration of specific subsets of cases that are structurally related to those that are at the heart of this paper-those construing Panetti v. Quarterman ${ }^{71}$ and a defendant's right to neurological testing ${ }^{72}$-reveals a series of Strickland-based decisions that make a mockery out of the notion of a constitutionally-based standard. ${ }^{73}$ Witnesses before an ABA Task Force characterized counsel's performance in death penalty cases in general variously as "'scandalous,' 'shameful,' 'abysmal,' 'pathetic,' [and] 'deplorable." "74 In the words of one commentator, Strickland serves merely as a "gatepost[.] on the road to legal condemnation." 75

This all flies in the face of what the American Bar Association has tried, vainly, to do. ABA Supplemental Guideline 5.1 discusses those skill sets required in the provision of adequate counsel: cultural competency, knowledge of mental health signs and symptoms, and skills required in interviewing and record gathering.

67. Frierson v. Woodford, 463 F.3d 982 (9th Cir. 2006).

68. For a nearly-nihilistic view, see Amy R. Murphy, The Constitutional Failure of the Strickland Standard in Capilal Cases Under the Eighth Amendment, 63 LAW \& CoNTEMP. PROBS. 179, 205 (2000) ("A comparison of the cases that cleared the Strickland hurdle and those that did not suggests that all that really matters in [ineffective assistance of counsel] claims is the appellate court's view of the case.").

69. See, e.g., Calhoun, supra note 8.

70. The Strickland standard was eroded even further in Spriggs v. Collins, 993 F.2d 85, 88 (5th Cir. 1993) (no violation of Strickland in non-capital sentencing case unless defendant can demonstrate that the sentence would have been "significantly" less severe). For other examples of courts rejecting Strickland claims, see, e.g., PERLIN, supra note 1, at 256-57 n. 98 (listing cases).

71. 551 U.S. 930 (2007) (competency to be executed).

72. See PERLIN, supra note 1, at 93-108.

73. For an array of such cases, see $i d$. at 133.

74. Robbins, supra note 26 , at 69 (citation omitted).

75. Bright, Dealh by Lollery, supra note 5, at 683.

76. See Russell Stetler, The Mystery of Mitigation: What Jurom Need to Make a Reasoned Moral Response in Capital Sentencing, 11 U. PA. J.L. \& SOC. CHANGE 237, 263 (2007-08). 
But the Supreme Court's clear disinclination-and lower federal courts' even clearer disinclination-to carefully assess counsel's performance in providing criminal defense services is reflected squarely in its failure to insist that defense counsel must comply with this Guideline. ${ }^{77}$ On balance, Strickland is a nonstandard-a disastrous nonstandard-that provides virtually no safeguards for criminal defendants with mental disabilities. For those facing the death penalty, it is little more than an empty shell. ${ }^{78}$

\section{Supreme Court Developments After Strickland}

In the years following the Strickland decision, the Supreme Court demonstrated overwhelming ambivalence about counsel adequacy issues. In Alvord $v$. Wainwright, ${ }^{79}$ the Court denied certiorari in a case where defense counsel accepted his client's refusal to rely on the insanity defense with no independent investigation of his client's mental or criminal history, despite the fact that the record demonstrated unequivocally that the defendant had a history of mental illness and had been acquitted on insanity grounds six years prior to his indictment in the current case. ${ }^{80}$ Justice Marshall concluded in his dissent from the certiorari denial:

The lower court has countenanced a view of counsel's constitutional duty that is blind to the ability of the individual defendant to understand his situation and usefully to assist. in his defense. The result is to deny to the persons who are most in need of it the educated counsel of an attorney. ${ }^{81}$

77. Michael L. Perlin \& Valerie R. McClain, "Where Souls Are Forgotlen": Cullural Competencies, Forensic Evaluatioms and International Human Rights, 15 PSYCH IOL. PUB. POL'Y \& L. 257, 260 (2009).

78. Ironically, in cases in which counsel actually does perform effectively (far beyond the minimal standards of Strickland), they may be criticized by judges in the Fifth Circuit for having "torn" "the veil of civility" by their vigorous representation. See Bell v. Lynaugh, 858 F.2d 978, 985-86 (5th Cir.1988) (Jones, J., specially concurring), cert. denied.492 U.S. 925 (1989). Bell's death sentence was ultimately vacated on the basis of his intellectual disability. See Bell v. Cockrell, 310 F.3d 330, 331 (5th Cir. 2002); Email from Edward Chikofsky, Bell's appellate counsel, to the authors (March 14, 2019) (on file with authors). Bell is discussed infra note 137.

79. 469 U.S. 956 (1984).

80. See id.; cf. People v. Frierson, 705 P.2d 396 (Cal. 1985) (holding that defense counsel could not refuse to honor defendant's clearly expressed desire to present diminished capacity defense at guilt/special circumstances phase of death penalty case; question was not merely a tactical decision). On the application of Strickland in insanity defense cases in general, see, e.g., Gerwig-Moore supra note 64; PERIIN \& CUCOLO, supra note 4, § 14-1.6, at 14117 to $14-127$.

81. Alvord, 469 U.S. at 963 . 
More recently, when the Court returned to this question again, it did demonstrate, in some cases, greater sensitivity to the issues at hand. ${ }^{82}$ By way of example, in Williams $v$. Taylor, it found that a death penalty petitioner had been denied his constitutionally guaranteed right to effective assistance of counsel when his lawyers failed to develop, investigate, and present substantial mitigating evidence during the sentencing phase of his capital trial, ${ }^{83}$ a position it adhered to in subsequent cases. ${ }^{84}$ It later backtracked in Schriro $v$. Landrigan, ${ }^{85}$ a case involving a defendant who had a history of "recurr[ing] placements in ... a psychiatric ward." reversed a habeas grant, finding that defense counsel's failure to present mitigating evidence during the sentencing phase did not deprive petitioner of effective assistance of counsel. ${ }^{8}$

The Supreme Court has returned to this issue multiple times since its decision in Strickland, though, as we note in Part III, these cases have had little impact on the Fifth Circuit's jurisprudence in this area of the law. In 2000, it reversed a death penalty conviction,: ruling that the defendant was denied his constitutionally-" guaranteed right to effective assistance of counsel when his lawyers failed to investigate and present substantial mitigating evidence during a capital case's sentencing phase. ${ }^{88}$ But it returned with much greater focus after the American Bar Association promulgated revised "Guidelines for the Appointment and Performance of Defense Counsel in Death Penalty Cases" (Guidelines). These Guidelines sought to significantly elevate the standard of representation in death penalty cases, providing the partial basis for the2003 Supreme Court decision in Wiggins v. Smith ${ }^{89}$ which established the requirement for a thorough and comprehensive mitigation review.

82. But see Wood v. Allen, 558 U.S. 290, 303-04 (2010) (argument that state-court decision involved unreasonable application of Strickland because counsel failed to make reasonable investigation of petitioner's mental deficiencies before deciding not to pursue or present such evidence was not "fairly included" in questions presented and thus would not be addressed by Court); Cullen v. Pinholster, 563 U.S. 170 (2011) (finding that the state court could have reasonably concluded that petitioner failed to rebut presumption of competence mandated by Strickland, and could have reasonably concluded that petitioner was not prejudiced by counsel's allegedly deficient performance).

83. See Williams v. Taylor, 529 U.S. 362 (2000).

84. See, e.g., Rompilla v. Beard, 545 U.S. 374 (2005) (holding that failure to adequately investigate is ineffective assistance of counsel); Wiggins v. Smith, 539 U.S. 510 (2003) (following Rompilla). Bul see Williams, supra note 1, at 1461 (survey of lower court decisions both before and after Wiggins indicates that capital defendants did not achieve any greater success in obtaining relief after Wiggins than they did before Wiggins).

85. 550 U.S. 465 (2007).

86. Id. at 483 (Stevens, J., dissenting).

87. Id. at $478-81$.

88. Williams, 529 U.S. 362.

89. 539 U.S. 510 (2003). 
In Wiggins, the Court found that the defendant's attorney failed to conduct a comprehensive social history of his client, thus violating his Sixth Amendment rights. ${ }^{90}$ Specifically, the Court set forth the requirement that mitigation investigations include efforts to discover "all reasonably available" mitigating evidence, as well as evidence to rebut any aggravating evidence that may be introduced by the prosecutor. ${ }^{91}$ Wiggins specifically incorporated the Guidelines, whose objective was to "set forth a national standard of practice for the defense of capital cases in order to ensure high quality legal representation for all persons facing the possible imposition or execution of a death sentence by any jurisdiction." 92

Under the Guidelines, at least one member of the defense team needed to be "qualified by training and experience to screen individuals for the presence of mental or psychological disorders or impairments." The Guidelines also recommended the inclusion of a mitigation expert, a mental health professional who possesses:

clinical and information-gathering skills and training that most lawyers simply do not have. They have the time and ability to elicit sensitive, embarrassing and often humiliating evidence... that the defendant may have never disclosed. They have the clinical skills to recognize such things as congenital, mental or neurological conditions, to understand how these conditions may have affected the defendant's development and behavior, and to identify the most appropriate experts to examine the defendant or testify on his behalf. ${ }^{94}$

90. Id. at $525-38$.

91. Id. at 524 .

92. ABA Guidelines for the Appointment and Performance of Defense Counsel in Death Penally Cases 1.1(A) (rev. ed. 2003), in 31 HOFSTRA L. REV. 913, 919 (2003) [hereinafter Guidelines].

93. $I d$. at 952 . "Creating a competent and reliable mental health evaluation consistent with prevailing standards of practices is a time consuming and expensive process. Counsel must compile extensive historical data, as well as obtaining a thorough physical and neurological examination. Diagnostic studies, neuropsychological testing, appropriate brain scans, blood tests or genetic studies, and consultation with additional mental health specialists may also be necessary." Id. at 956. In this context, see Alison J. Lynch, Velerans on Death Row: Strategies for Miligating Capilal Sentences for Defendants with Military Service History, 32 CRIM. JUST. 4 (2018).

94. Guidelines, supra note 92 , at 959 (citations omitted). For a thoughtful inquiry into the role of the mitigation specialist, see Emily Hughes, Mitigating Death, 18 ConNELL J.L. \& PUB. POL'Y 337 (2009). On the diverse set of skills needed to engage in fact investigation, see Russell Stetler, Miligation Investigation: A Duly That Dermands Expert Help but Can't Be Delegated, 31 The CHAmPION 61 (2007). On the significance of the ABA Guidelines in general, see Russell Stetler \& W. Bradley Wendel, The ABA Guidelines and the Norms of Capital Defense Representalion, 41 HOFSTRA L. REV. 635 (2013). 
Several years later, the Supreme Court returned to this issue in Rompilla $v$. Beard, ${ }^{95}$ holding that counsel's failure to examine Rompilla's prior conviction file constituted deficient performance. It based this conclusion on its findings that counsel knew the prosecution intended to use Rompilla's prior conviction to prove an aggravating circumstance, and that the prior conviction file, which contained significant mitigation evidence, would likely have caused the jury to reach a different result had it been presented to them. ${ }^{96}$ Although a lengthy scholarly analysis soon after Rompilla was decided concluded that "the Court has recognized the need to rework Strickland, ${ }^{\prime 77}$ subsequent research-surveying lower court decisions both before and after Wiggins-indicated that capital defendants did not achieve any greater success in obtaining relief after Wiggins than they did before Wiggins. ${ }^{98}$ As Professor John Blume and a colleague ruefully noted, "[d]espite the Supreme Court's clear message, a number of courts still remain hostile to ineffective assistance of counsel claims and are still willing to put a judicial stamp of approval on appallingly inadequate representation." "

The Court has continued to assess the underlying issues that have been presented in Strickland claims. Six years after Wiggins, it ruled that defense counsel's failure to uncover and present during penalty phase any mitigating evidence regarding defendant's mental health, family background, or military service was deficient. ${ }^{100}$

95. 545 U.S. $374(2005)$.

96. Id. at 390,393 . On the "shallow[ness]" of the investigation in Rompilla, see Sean O'Brien \& Kathleen Wayland, Implicil Bias and Caprital Decision-Making: Using Narrative to Counter Prejudicial Psychiatric Labels, 43 Hofstra L. Rev. 751, 775-77 (2015).

97. Whitney Cawley, Raising the Bar: How Rompilla v. Beard Represents the Court's Increasing Efforts to Impose Stricter Slandards for Defense Lawyering in Capilal Cases, 34 PEPP. L. REV. 1139,1185 (2007).

98. Williams, supra note 1 , at 1461 . These findings sadly contradict the optimistic predictions of respected scholars and criminal law practitioners in the immediate aftermath of Williams, Wiggins, and Rompilla. See, e.g., James S. Leibman \& Lawrence C. Marshall, Less Is Better: Justice Stevens and the Narrowed Dealh Penally, 74 FORDHAM L. REv. 1607, 1666 (2006) (Cases in question "reveal a willingness on the Court's part to scrutinize death sentences more vigorously, particularly in cases falling near the mitigated circumference."); Rigg, supra note 57 , at 88 (characterizing these cases as the "[t]urning [p]oint" in adequacy of counsel law).

99. John H. Blume \& Stacey D. Neumann, “Il's Like Deja Vu All Over Again”: Williams v. Taylor, Wiggins v. Smith, Rompilla v. Beard and a (Partial) Relum to the Guidelines Approach to the Effective Assistance of Counsel, 34 AM. J. CRIM. L. 127, 159-60 (2007).

100. Porter v. McCollum, 558 U.S. 30, 40 (2009). On how Porter nonetheless "fail[s] to acknowledge the reality of mental illness" in death penalty cases, see Michael L. Perlin, "I Expecled It to Happen/I Knew He'd Lost Control": The Impact of PTSD on Criminal Sentencing after the Promulgation of DSM-5, 2015 Utah L. Rev. 881, 926 (2015). Porter is also discussed in Phillip H. Cherney, The Lamentable Mr. Toad: On the Wild Ride with Claims of Ineffective Assislance of Counsel in Capital Cases Before the United States Supreme Court, 42 LINCOLN L. REV. 1, 26-28 (2014-15). 
And in its most recent term, ${ }^{101}$ the Court returned to this issue once again, in Ayestas $v$. Davis, ${ }^{102}$ holding that the lower courts applied too stringent of a standard in rejecting defendant's request for funding so that he could develop arguments that his trial counsel's failure to investigate petitioner's mental health and alcohol and drug abuse rose to the level of ineffectiveness of counsel. ${ }^{103}$

But, as we noted previously, lower court cases have been wildly inconsistent, and many have simply ignored all the post-Strickland decisions that seemed to have resuscitated at least a partially-sound adequacy of counsel standard. Although some reversed convictions or granted writs of habeas corpus based on findings of ineffectiveness, the vast majority have affirmed convictions or the denial of habeas writs, concluding that counsel's performance was adequate under the Strickland $v$. Washington standard. ${ }^{104}$ In sum, the vast majority of Strickland-based decisions "make a mockery out of the notion of a constitutionally based standard." 105

\section{SOME JURISPRUDENTIAL FILTERS}

There is no longer any question-there cannot be any question-as to how it is impossible to understand developments in this area of the law without a full consideration of the malignant and corrosive impact of sanism, pretextuality, heuristic reasoning and (false) "ordinary common sense." "These factors have "poisoned and corrupted" all of mental disability law," ${ }^{107}$ have "malignantly

101. After Porter but before Ayestas $v$. Davis, the Court had rejected defendant's parallel arguments. See Smith v. Spisak, 558 U.S. 139 (2010) (assuming counsel performed deficiently in making a penalty-phase closing argument that allegedly understated the facts upon which defense experts based their mental illness conclusions, defendant was not prejudiced, as an element of ineffective assistance of counsel).

102. 138 S. Ct. 1080 (2018).

103. The case turned on the interpretation of a federal statute, 18 U.S.C. $\$ 3599(f)$, which provides, in relevant part, that, in cases in which the death penalty may potentially be sought, a district court "may authorize" funding for "investigative, expert, or other services ... reasonably necessary for the representation of the defendant," and the application of the procedural default doctrine. Ayesias was a Fifth Circuit case, and one of the first commentaries about the case notes the rarity of a unanimous Supreme Court death penalty decision in its "rebuk [e]" of the Fifth Circuit. See Laura Schaefer, The Ethical Argument for Funding in Clemency: The "Mercy" Function and the ABA Guidelines, 46 HOFSTRA L. REV. 1257, 1274 (2018).

104. Cases are discussed in PERLIN \& CuCOLO, supra note 4, § 17-3.6.

105. Id., \$6-3.3.3.

106. See Michael L. Perlin \& Heather Ellis Cucolo, "Tolling for the Aching Ones Whose Wounds Cannol Be Nursed": The Marginalization of Racial Minorities and Women in Institutional Mental Disability Law, 20 J. GENDER, RACE \& JUSTICE 431, 451 (2017).

107. Michael L. Perlin \& Meredith R. Schriver, "You Might Have Drugs at Your Command": Reconsidering the Forced Drugging of Incompetent Pre-trial Detainees from the Perspectives of International IIuman Rights and Income Inequality, 8 ALBANY GOV'T L. REV. 381, 394 (2015). 
distort[ed] both the legislative and judicial processes," ${ }^{108}$ and have similarly "distort[ed] our abilities to rationally consider information." ${ }^{109}$ We believe it is impossible to understand developments in this area of the law without considering these factors, and their impact (both conscious and unconscious) on fact-finders. ${ }^{110}$

\section{A. Sanism}

Sanism dominates the entire representational process in cases involving individuals with mental disabilities, ${ }^{111}$ and it reflects what civil rights lawyer Florynce Kennedy has characterized as the "pathology of oppression." 112 It is an irrational prejudice of the same quality and character of other irrational prejudices that cause (and are reflected in) racism, sexism, homophobia, and ethnic bigotry. Sanism is "largely invisible and largely socially acceptable." "113 "It "infects both our jurisprudence and our lawyering practices... [and is] based predominantly upon stereotype, myth, superstition, and deindividualization," "114 in "unconscious response to events both in everyday life and in the legal process." Its "corrosive effects have warped all aspects of the criminal process." 116

108. Michael L. Perlin, "Simplify You, Classify You": Stigma, Stereolypes and Cizril Rights in Disability Classification Systems, 25 GA. ST. U. L. REV. 607, 607 (2009).

109. Id. at 622 .

110. See generally Perlin, Sanist Lives, supra note 3.

111. Michael L. Perlin \& Alison J. Lynch, "Mr. Bad Example": Why Lauyers Need to Embrace Therapeutic Jurisprudence to Root ont Sanism in the Representation of Persons with Mental Disabilities, 16 WYO. L. REV. 299,300 (2016).

112. Morton Birnbaum, The Right to Trealment: Some Comments on Its Development, in MEdical, MORAL AND Legal Issues IN HeAlTh CARE 97, 107 (Frank Ayd ed., 1974) (quoting Kennedy).

113. Michael L. Perlin, "And My Best Friend, My Doctor, Won't Even Say What It Is I've Gol": The Role and Significance of Counsel in Right to Refuse Treatment Cases, 42 SAN DiEgo L. REv. 735, 750 (2005).

114. See, e.g., Michael L. Perlin, "Everybody Is Making Love/Or Else Expecting Rain": Considering the Sextal Autonomy Rights of Persons Institutionalized Because of Mental Disability in Forensic Hospitals and in Asia, 83 U. WASH. L. REv. 481, 486 (2008). On the "malignancy" of these stereotypes, see Michael L. Perlin, "Half-Wracked Prejudice, Leaped Forth": Sanism, Prelexiuality, and Why and How Mental Disahility Law Developed as It Did, 10 J. ConTEMP. LEG. Iss. 3, 30 (1999) (hereinafter Perlin, Italf-Wracked).

115. Perlin \& Cucolo, supra note 106, at 451-52. On how "sanist myths exert especially great power over lawyers who represent persons with mental disabilities," see Perlin, supra note 108 , at 621

116. Perlin \& Schriver, supra note 107, at 394. 


\section{B. Pretextuality}

Pretextuality describes the ways in which courts accept testimonial dishonesty - especially by expert witnesses - and engage similarly in dishonest (and frequently meretricious) decision-making. ${ }^{117}$ This phenomenon is "especially poisonous where courts accept witness testimony that shows a "high propensity to purposely distort their testimony in order to achieve desired ends." 118 It "breeds cynicism and disrespect for the law, demeans participants, and reinforces shoddy lawyering, blasé judging, and, at times, perjurious and/or corrupt testifying." ${ }^{119}$

\section{Heuristics}

Heuristics refers to a cognitive psychology construct that describes the implicit thinking devices that individuals use to simplify complex, information-processing tasks. The use of such heuristics frequently leads to distorted and systematically erroneous decisions, and it leads decision-makers to ignore or misuse items of rationally useful information. ${ }^{120}$ Judges thus focus on information that confirms their preconceptions (i.e., confirmation bias), to recall vivid and emotionally charged aspects of cases (i.e., the availability heuristic), and to interpret information that reinforces the status quo as legitimate (i.e., system justification biases). ${ }^{121}$

117. See Michael L. Perlin \& Naomi Weinstein, Said I, 'Bul You Have No Choice': Why a Lawyer Must Ethically Honor a Client's Decision About Mental Health Treatment Even If It Is Not What S/he Would Have Chosen, 15 CARdozo Pub. L. POL'y \& ETHICS J. 73, 85 (2016) ("Pretextual devices such as condoning perjured testimony, distorting appellate readings of trial testimony, subordinating statistically significant social science data, and enacting purportedly prophylactic civil rights laws that have little or no 'real world' impact, dominate the mental disability law landscape. Judges in mental disability law cases often take relevant literature out of context, misconstrue the data or evidence being offered, and/or read such data selectively, and/or inconsistently. Other times, courts choose to flatly reject this data or ignore its existence. In other circumstances, courts simply 'rewrite' factual records so as to avoid having to deal with social science data that is cognitively dissonant with their view of how the world 'ought to be." ) (citations omitted).

118. Perlin \& Cucolo, supra note 106, at 452; see also Michael L. Perlin, Morality and Pretextuality, Psychiatry and Law: Of "Ordinary Common Sense," Heuristic Reasoning, and Cognilive Dissonance, 19 Bull. AM. ACAD. PsYChiatry \& L. 131, 133 (1991).

119. Perlin, supra note 113 , at 750-51. On how courts "employ pretextuality as a 'cover' for sanist-driven decisionmaking," see Perlin, Half-Wracked, supra note 114, at 30 .

120. Heather Ellis Cucolo \& Michael L. Perlin, "They're Planting Stories in the Press": The Impact of Media Distortions on Sex Offender Law and Policy, 3 U. DENV. CRIM. L. ReV. 185, 212 (2013).

121. Eden B. King, Discrimination in the 21st Century: Are Science and the Law Aligned?, 17 PSYCHOL. PUB. POL'Y \& L. 54, 58 (2011); see also John T.Jost \& Mahzarin R. Banaji, The Role of Stereolyping in System-Justification and the Production of False Conscionusness, 33 BRIT. J. SOC. PSYCHOL. 1 (1994); Amos Tversky \& Daniel Kahneman, Availability: A Heuristic for Judging Frequency and Probability, 5 COGNITIVE PSYCHOL. 207 (1973). 
Especially pernicious is the "vividness" heuristic, through which "one single vivid, memorable case overwhelms mountains of abstract, colorless data upon which rational choices should be made." 122 The use of these heuristics blinds us "to the 'gray areas' of human behavior."

\section{D. "Ordinary Common Sense"}

Ordinary common sense (OCS) is "a powerful unconscious animator of legal decision making ${ }^{124}$ that reflects "idiosyncratic, reactive decisionmaking," "25 and "is a psychological construct that reflects the level of the disparity between perception and reality that regularly pervades the judiciary in deciding cases involving individuals with mental disabilities." 126

OCS is self-referential and non-reflective: "I see it that way, therefore everyone sees it that way; I see it that way, therefore. that's the way it is." "127 Importantly, it is supported by our reliance .. on a series of heuristics-cognitive-simplifying devices that distort our abilities to rationally consider information. ${ }^{128}$ It presupposes two "self-evident" truths: "First, everyone knows how to assess an individual's behavior. Second, everyone knows when to blame someone for doing wrong." 129

122. Michael L. Perlin, "The Borderline Which Separated You from Me": The Insanily Defense, the Authoritarian Spinit, the Fear of Faking, and the Culture of Punishment, 82 IOWA L. REV. 1375, 1417 (1997); see also Michael L. Perlin, "There's No Success like Failure/and Failure's No Success at All": Exposing the Pretextuality of Kansas v. Hendricks, 92 Nw. U. L. REv. 1247, 1255 n. 51 (1998) (Behavioral scientists are aware of the power of what Dr. David Rosenhan has characterized as the "distortions of vivid information." As part of this phenomenon, "concrete and vivid information" about a specific case "overwhelms" the abstract data ... upon which rational choices are often made." David Rosenhan, Psychological Realilies and Judicial Policies, STAN. LAW., Fall 1984, at 10, 13-14. Thus, "the more vivid and concrete is better remembered, over recitals of fact and logic." Marilyn Ford, The Role of Extralegal Factors in Jury Verdicts, 11 JUST. SYS. J. 16, 23, (1986)).

123. Michael L. Perlin, "She Breaks Just Like a Little Girl": Neonaticide, the Insanity Defense, and the Irrelevance of "Ordinary Common Sense," 10 WM. \& MARY J. WOMEN \& L. 1, 6 (2003); see also Perlin \& Cucolo, supra note 106 , at 452.

124. Michael L. Perlin, Psychodynamics and the Insanity Defense: "Ordinary Common Sense" and Heuristic Reasoning, 69 NEB. L. REv. 3, 22-23, 29 (1990). See Richard K. Sherwin, Dialects and Dominance: A Study of Rhetorical Fields in the Law of Confessions, 136 U. PA. L. REV. 729, 737-38 (1988) (OCS is exemplified by the attitude of "[w] hat I know is 'self evident'; it is 'what everybody knows.' ").

125. Perlin, supra note 124, at 29.

126. Perlin \& Weinstein, supra note 117 , at $87-88$.

127. Id. at 88 .

128. See Perlin \& Cucolo, supra note 106, at 453.

129. Michael L. Perlin, Myths, Realities, and the Political World: The Anthropology of Insanity Defense Alitudes, 24 BULl. AM. ACAD. PSYCHLATRY \& L. 5, 17 (1996). 


\section{E. In the Context of Strickland Claims}

As we demonstrate in Part III, the quality of lawyering done in many of the cases in which Strickland claims were raised led inexorably to decisions that reflect the way that these factors continue to dominate the legal process. First, the decisions are, by and large, pretextual. Cases in which defense lawyers failed to look at any mitigation evidence ${ }^{130}$ even when such evidence was readily available, ${ }^{131}$ cases in which defense lawyers failed to prepare expert witnesses to testify $^{132}$ or to give psychiatric records to expert witnesses ${ }^{133}$ or to retain independent expert mental health witnesses, ${ }^{134}$ and cases in

130. E.g., Hammond v. Scott, 35 F.3d 559, 1994 WL 499681, at *4, n. 12 (5th Cir. 1994) ("According to Hammond's brief, this information included evidence that his father constantly beat his mother, abused his brothers, and raped and sexually abused his sisters (at least one time in front of Hammond) and that he was also beaten by his father and mother, many times in front of other people, causing his psychological trauma. When Hammond was nine, the father was beating the mother and an older brother shot and killed the father in the presence of Hammond and other family members. The brother then used a razor to mutilate the father's body. After this, Hammond began to have nightmares, hallucinations (primarily about 'Ozzie' who directs Hammond to harm others) and to abuse drugs. There was also some proof that Hammond is borderline mentally retarded (IQ 77) and suffers from severe psycho-pathology as well as paranoia and post-traumatic stress disorder. Antipsychotic drugs have reduced the delusions, but Hammond was unable to obtain those drugs at the time of the crime.")

131. See, e.g., Celestine v. Blackburn, 750 F.2d 353, 357 (5th Cir. 1984) (noting that mitigating evidence would have consisted of "the testimony of appellant's relatives, friends, and employers who would have asserted appellant's affection for his family and friends, their affection for him, his willingness to work hard without complaint, his conscientiousness and dependability, his faith, and his non-violent disposition. Some of the witnesses would have pleaded for appellant's life. Other evidence would have shown that tests in 1973 showed appellant to have an I.Q. of 69 , and that he committed the murder at the age of $25 . ")$.

132. E.g., Allen v. Stephens, 805 F.3d 617 (5th Cir. 2015); Castillo v. Stephens, 640 Fed.Appx. 283 (5th Cir. 2016).

133. E.g., Brown v. Cain, 104 F.3d 744 (5th Cir. 1997). In Broum, the defendant argued that his attorney failed to deliver his medical and juvenile records to his psychiatric expert. Id. at 751. Brown bolstered his argument that his psychological expert was "inadequately educated" by utilizing a psychiatrist at the post-conviction evidentiary hearing in state court, who concluded that the defendant "suffered from certain mental disorders that were not revealed in expert testimony at trial." Id. This argument was rejected by the state and district courts that ruled this psychiatrist was "the only expert among five retained by Brown" who reached that result regarding the identified disorders. This evidence did not establish a Strickland violation. Id. at 752.

134. See Appendix A (4) and (5), for lists of cases in which experts were neither utilized nor requested. For example, in Clark $v$. Collins, the defendant argued his attorney failed to retain an independent psychiatric evaluation to support a possible insanity defense which should be deemed ineffective assistance of counsel under Strickland. 19 F.3d 959, 964 (5th Cir. 1994). The court rejected Clark's claim because the psychiatric exam that was conducted by the psychiatrist at Rusk State hospital on a joint motion by the defense and the state "appeared very thorough" and there was "no reason to believe another psychiatrist might reach" a different conclusion. Id. Although habeas counsel presented evidence of "two medical opinions in conflict with [the psychiatrist], that "does not impel a contrary finding." Id. In a forthcoming manuscript, one of the authors (MLP) suggests that in some cases involving defendants with mental disabilities, tawo experts are required-one to provide an evaluation of the defendant's mental state, and one to explain to the fact-finders why their 'ordinary common sense,' is flawed; see Michael L. Perlin, "Deceived Me into Thinking/I Had 
which defense lawyers failed to present psychiatric evidence in cases in which bona fide incompetency status/insanity defense questions were raised ${ }^{135}$ all demonstrate an astonishing level of pretextuality by the court. Lawyers' failure to understand (and explain) the textures of mental illness, ${ }^{136}$ the impact of intellectual disability on behavior, ${ }^{137}$ to even understand when mental illness is present $^{138}$ (and the court's failure to hold such lawyers up to reasonable performance standards) is sanism of the rankest sort. ${ }^{139} \mathrm{~A}$ non-mental disability-focused case was reversed on non-Strickland

Something to Protect": A Therapeutic Jurisprudence Analysis of When Multiple Experts Are Necessary in Cases in Which Fact-Finders Rely on Heuristic Reasoning and “Ordinary Common Sense," L.J. SoC'L JUST. (forthcoming 2020); supra text accompanying notes 124-29.

135. See Appendix A (3) for a list of cases in which competency questions were not addressed. By way of example, in Crawford v. Epps, 353 Fed. Appx. 977 (5th Cir. 2009), the defendant claimed that his attorney was ineffective for failing to seek a competency evaluation prior to trial, basing his argument on an affidavit by a psychiatrist concluding that Crawford was "probably incompetent to stand trial." Id. at 991 . Although both the district and state courts agreed that "defense counsel was deficient for failing to seek a competency determination," they ruled that the defendant did not suffer "prejudice" under Sirickland. Id. In this context, consider how the Fifth Circuit has found no prejudice in cases involving textbook violations of Ake $v$. Oklahoma. 470 U.S. 68 (1985) (holding that indigent defendants seeking to plead insanity have a right to an independent expert). See, e.g., Crane v. Johnson 178 F.3d 309, 315 (5th Cir. 1999) (no prejudice in Ake violation); Hood v. Dretke 93 Fed. Appx. 665 (5th Cir. 2004) (Ake violation harmless error).

136. E.g., Barnard v. Collins, 958 F.2d 634 (5th Cir 1992). In Bamard, the defendant argued that several months before he committed the capital crime, his son-in law beat him in the head with a tire iron. Barnard's mother testified that since the beating incident, he needed "psychiatric help" Id. at 638. Barnard's argument centered on the fact that his attorney failed "to have a psychological expert evaluate [him, and] ... failed to obtain a medical examination to determine if he suffered from brain damage." Id. at 641. These arguments * were rejected by the court, stating "Barnard fails to demonstrate that his counsel [had] rea-. son to believe that Barnard suffered from a mental defect." $I d$. at 642 .

137. E.g., Bell v. Lynaugh, 828 F.2d 1085 (5th Cir. 1987). In Bell, the defendant argued his attorney was ineffective for failing to present or investigate psychiatric evidence of his "mental retardation" at the penalty phase of his trial. $I d$. at 1087 . Trial counsel called only one witness, the defendant's mother, who testified to Bell's low IQ of 54. Id. at 1088. In Bell's first capital trial, two state psychiatrists testified that Bell "was capable of conforming his actions to the law, and that he knew right and wrong, and that he had choices," and concluded that Bell was "a future danger to society." Id. at 1089. He was "borderline retarded but was responsible for his behavior" and he had "decreased impulse control" and was therefore "more likely to engage in violent criminal acts" Id. As a result, even though two defense experts, a psychiatrist and psychologist, were able to testify to Bell's low IQ his "mild mental retardation," and his "defective mental state," counsel decided not to present this evidence in mitigation. Id. However, the court found this decision was reasonable in order to avoid damaging state rebuttal evidence. $J d$. at 1090.

138. E.g., Freeman v. Stephens, 614 Fed. Appx. 180 (5th Cir. 2015). In Freeman, the defendant's attorney failed to conduct a deeper investigation into his possible mental illness by examining the mental history of his family which would have strengthened his argument that he suffered from depression, other medical disorders, and possible "toxic exposure" causing brain damage. Id. at 186-87. The court rejected the defendant's argument claiming Freeman's evidence of "brain dysfunction as a result of toxic exposure is classically doubleedged" and may have "increased the jury's assessment of future dangerousness." Id. at 187.

139. See Michael L. Perlin, "His Brain Has Been Mismanaged with Greal Skill": How Will Jurors Respond to Neuroimaging Testimony in Insanily Defense Cases? 42 AKRON L. REV. 885, 900 (2009) (discussing "sanist myths" upon which jurors rely, including the "sanctioning of the death penalty in the case of mentally retarded defendants."). 
grounds in which counsel apparently did not object to "emotionally charged" and inflammatory evidence of the victim's admirable personal characteristics, characteristics which the Court noted was "altogether irrelevant to the question of whether David Rushing should be put to death,"110 a clear example of the powers of heuristic reasoning.

The role of OCS in such cases is well known. ${ }^{141}$ By way of example, the Supreme Court's use of public opinion polling in determining the constitutionality of certain executions ${ }^{142}$ relied, implicitly, on such ordinary common sense. ${ }^{149}$ So it is that we use false OCS to "generalize and wrongly stereotype persons with mental disorders in order to justify prejudiced decision making against them." 144 Also, jurors self-reflectively reject consideration of the sort of scientific evidence that must be relied on in efforts to demonstrate mental impairment as a basis for mitigation, as such evidence may be "beyond the understanding of jurors who rely on ordinary common sense in decision-making."

In short, the use of these factors contaminates these aspects of death penalty law, ${ }^{146}$ and it is impossible, we believe, to understand the prevailing case law until we contextualize the decisions in question with these factors.

140. Rushing v. Butler, 868 F.2d 800, 804 (5th Gir. 1989).

141. On why this false OCS should be irrelevant in one subset of homicide cases (those of neonaticide), see Perlin, supra note 114 , at 4.

142. See Atkins v. Virginia, 536 U.S. 304 (2002) (using such polling data to support its decision that the execution of persons with mental retardation (now, intellectual disability) was cruel and unusual punishment).

143. For a critical appraisal, see Tracy E. Robinson, By Popular Demand? The Supreme Court's Use of Public Opinion Polls in Atkins v. Virginia, 14 GEO. MASON U. CIV. RTS. L.J. 107 (2004); David A. Singleton, What Is Punishment?: The Case for Considering Public Opinion Under Mendoza-Martinez, 45 SETON Hall L. REv. 435 (2015) (on the punitiveness of certain legislative sanctions).

144. Grant H. Morris, The Evil That Men Do: Perverting Justice to Punish Perverts, 2000 U. ILL. L. REV. 1199, 1201 n. 13 (2000); see also Perlin \& Lynch, supra note 111, at $311 \mathrm{n} .76$ (citing Morris, supra note 144).

145. Ellen Byers, Mentally IIl Criminal Offenders and the Strict Liability Effect. Is There Hope for a Just Jurispmudence in an Era of Responsibility/Consequences Talk?, 57 ARK. L. REV. 447, 499 n. 336 (2004) (quoting Michael L. Perlin, Unpacking the Myths: The Symbolism Mythology of Insanity Defense Jurispmudence, 40 CASE W. REs. L. REv. 599, 679 (1989-90)); see also id. (quoting Edward J. Imwinkelried, The Standard for Admilting Scientific Evidence: A Critique from the Perspective of Juror Psychology, 28 VILL. L. REV. 554, 564 (1982-83)) (noting that "common sense suggests that lay jurors with little or no background in science will have difficulty understanding complex, technical testimony").

146. See Michael L. Perlin, "Your Old Road Is/ Rapidly Agin'”: Intermational Human Rights Standards and Their Impact on Forensic Psychologists, the Practice of Forensic Psychology, and the Conditions of Institutionalization of Persons with Mental Disabilities, 17 WASH. U. GLOBAL STUDIES L. REv. 79, 100 (2018) (noting that sanism and pretextuality contaminate all aspects of mental disability law). 


\section{THE DATA}

\section{A. Methodology}

We examined Strickland claims of ineffective assistance of counsel that involved any aspect of a capital defendant's mental health. In order to identify these specific cases, we used the following steps in our methodology. First, we utilized the Westlaw database to obtain a list of relevant cases. Our search was limited to cases raised in the Fifth Circuit Court of Appeals, which includes cases originating from Texas, Mississippi, and Louisiana. This circuit was the focus because it included the vast majority of death penalty cases out of all the circuits, because a significant number of the most important death penalty cases since Strickland that have reached the Supreme Court have come from this circuit, ${ }^{147}$ because the Fifth Circuit has shown a stunning disregard of mitigation evidence in all sorts of death cases, ${ }^{148}$ and because, in a parallel area (competency to be executed), the Fifth Circuit has demonstrated an equally-stunning disregard for constitutional law. ${ }^{149}$

The following search terms were used: mental* and "death penalty." This search generated a list of 355 cases. Next, we completed

147. See Panetti v. Quarterman, 551 U.S. 930 (2007) (competency to be executed); Banks v. Dretke, 540 U.S. 668 (2004) (prosecutorial misconduct); Carol Steiker \& Jordan Steiker, A Tale of Two Nations: Implementation of the Death Penalty and Execuling $v$. Symbolic States of the United States, 84 TEX. L. REv. 1869, 1902 (2006) (noting that "courts within the Fifth Circuit were less likely than courts in most other circuits to authorize full appeals of capital claims denied in federal district court [and] have also been less inclined to hold evidentiary hearings than courts in other circuits ...."); id. at 1903 ("The Fifth Circuit has a relatively low rate of granting relief in cases addressed on the merits."). Many other significant death penalty cases in the pre-Sirickland era also arose in the Fifth Circuit. See, e.g., Barefoot v. Estelle, 463 U.S. 880 (1983) (testimony as to future dangerousness admissible at penalty phase in capital punishment case); Estelle v. Smith, 451 U.S. 454 (1983) (scope of forensic examiner's duty to inform a criminal defendant of potential disclosure of information shared during a forensic interview); see generally PERLIN, supra note 1.

148. See Steiker \& Steiker, supra note 147, at 1903 ("In the seventeen years since [the Supreme Court decided Penry v. Lynaugh, 492 U.S. 302 (1989)], the Fifth Circuit has denied relief in at least ninety-eight cases involving Penry claims: seventy-two of those inmates have already been executed."); see also Penry, 492 U.S. at 322 ("[M] itigating evidence of mental retardation and childhood abuse has relevance to [a defendant's] moral culpability [to enable a jury] to express its 'reasoned moral response' to that evidence in determining whether death was the appropriate punishment.").

149. By way of example, in Panetti $v$. Quarterman, Panetti's lawyers had told the Supreme Court in their petition for certiorari that two decades had passed since the Supreme Court had decided Ford v. Wainwright, 477 U.S. 399 (1986), the Supreme Court's initial modern decision on the question of competency to be executed, and that the Fifth Circuit had yet to find a single death row inmate incompetent to be executed. Panetti v. Quarterman, 2006 WL 3880284 , at $* 26$ (2006) (appellant's petition for certiorari). During this same period, the State of Texas executed 360 people. Id.; see also Michael L. Perlin, "Good and Bad, I Defined These Terms, Quite Clear No Doubl Somehow": Neuroimaging and Competency to be Execuled afler Panetti, 28 BeHAV. SCI. \& L. 671, 672 n. 9 (2010). 
an identical search in the LexisNexis database. This search generated a list of 382 of cases. There were 23 cases that appeared in the Westlaw search that did not appear on the LexisNexis search. These 23 cases were added to the 382 cases from LexisNexis, making a complete list of 405 cases. After closer examination, ${ }^{150}$ we were left with a final list of 198 distinct capital cases in the Fifth Circuit that included a Strickland claim of ineffective assistance of counsel due to a mental disability-related issue which includes mental illness and intellectual disabilities.

Of this universe, there were 13 cases $(6.5 \%)$ in which Strickland was the basis of a reversal, a remand, a vacation or a grant of a certificate of appealability. ${ }^{151}$ These reversals basically fall into these categories:

(a) where the trial attorney admitted unprofessional error(s) thus disallowing reliance on the 'strategic choice' rationale posited in Strickland ${ }^{152}$ (31\%);

(b) where the trial attorney exhibited an erroneous understanding of state law $(23 \%)$;

(c) where an insignificant amount of time was spent on the case investigation (either the casein main or the penalty phase) $(54 \%)$;

(d) where the behavior of the defendant before or during the trial was, simply, bizarre $(15 \%) ;{ }^{153}$

(e) where the court mentioned multiple errors that resulted in egregious cumulative error $(15 \%) ; i^{154}$ and

(f) where the defendant argued intellectual disability as part of his ineffective assistance of counsel claim $(38 \%)$.

150. Of these 405 cases, 127 of them were excluded because the Strickland claim did not deal with a mental health issue; 27 cases were excluded because they were not capital; 11 cases did not contain enough information to code the cases accurately, as there was only a decision posted to the law database and there was not enough information to code these cases properly; 27 cases included a defendant for which the Strickland claim was already coded for using a previous court decision; 10 more possible cases were excluded because the opinion was written prior to the Strickland decision.

151. See Appendix A (2) and Appendix B. Under 28 U.S.C.A. $\$ 2253$, the certificate of appealability statute, mandates that unless a circuit justice or judge issues a certificate of appealability, an appeal from the denial of habeas relief may not be taken to the court of appeals. See Moore v. Quarterman, 517 F.3d 781 (5th Cir. 2008).

152. Strickland v. Washington, 466 U.S. 668,699 (1984).

153. See, e.g., Saldaño v. Davis, 701 Fed. App'x 302 (5th Cir. 2017), cert. denied, 2019 WL 6107808 (2019); Zimmerman v. Cockrell, 2002 WL 32833097 (5th Cir. 2002).

154. See, e.g., Koon v. Cain, 77 Fed. App'x 381, 386 (5th Cir. 2008), discussed infra text accompanying notes 165-69; Moore v. Johnson, 194 F.3d 586, 619 (5th Cir. 1999). 
However, even this paltry number of reversals creates a false consciousness. When further research is done to determine what happened following the remand, we learn that in only one of these cases was there an actual ultimate reversal on the merits. ${ }^{155}$ In all others, the conviction was ultimately affirmed, or in a negotiation, the defendant agreed to plead to life imprisonment (in all but one case without the possibility of parole), and at least one defendant has subsequently been executed. ${ }^{156}$

\section{B. About Cohorts of the Cases}

\section{Introduction}

In this section, we will (1) discuss the thirteen cases in which the decision in question was other than an affirmance of the conviction, (2) discuss the "back stories" of those cases as to what happened following reversal or remand (in those instances where that information was available), and (3) also discuss one cohort of the nineteen cases in which Strickland claims were rejected, in spite of the fact that trial counsel proffered no evidence or testimony on mitigation whatsoever. Importantly, in most of the cases in which there were successful Strickland arguments made to the Fifth Circuit, there were multiple errors found below. ${ }^{157}$

\section{Reversals or Remands}

\section{a. Counsel Admission of Error}

Trial counsel or the defense expert admitted error in $38 \%$ of the Strickland reversals. For example, Alvin Scott Loyd was convicted and sentenced to death for first degree murder in Louisiana. ${ }^{158}$ The circuit court ruled that Loyd's counsel was deficient in not procuring a neutral psychological expert to examine the defendant. ${ }^{159}$ This failure was not the result of a strategic decision, and

155. See Walbey v. Quarterman, 309 Fed. App'x 795, 2009 WL 113778 (5th Cir. 2009).

156. Kevin Lee Zimmerman. See Appendix B. For a list of all defendants who have been executed in the cohort that is the subject of this study, see Appendix A (7). For a list of all cases in which convictions were affirmed, see Appendix A (1).

157. See infra text accompanying notes 224-35.

158. See State v. Loyd, 459 So. 2d 498 (1984).

159. Loyd v. Whitley, 977 F.2d 149, 152 (5th Cir. 1992). 
counsel even stated he did not feel competent to handle the case.$^{160}$ At the state habeas hearing, the attorneys expressed dissatisfaction with their representation of the defendant in the 1985 sentencing trial. The circuit court found that the issue of sanity was clearly a critical issue, and, therefore, the subsequent issue of mental health related mitigation was obviously extremely important. ${ }^{16}$ The decision not to pursue this crucial line of investigation in a capital case was deemed professionally unreasonable. ${ }^{162}$

Another case that provides a striking example of this phenomenon is the case of Carl Daniel Lockett. ${ }^{163}$ In the case, Lockett was convicted of capital murder in Mississippi and sentenced to death. ${ }^{164}$ The defendant killed two people (a husband and wife) for which he was tried separately, convicted, and sentenced to two death sentences in a consolidated proceeding. ${ }^{165}$ During appeals, the defendant argued that his Sixth Amendment right to effective assistance of counsel was violated, claiming that his defense attorney failed to present any mitigation in the sentencing phase of the trial. ${ }^{166}$ Counsel, in fact, admitted to not spending enough time on Lockett's case due to his mother's illness and his appointment to two other capital murder trials. ${ }^{167}$ An investigation would have revealed that Lockett suffered from an organic brain abnormality and had been previously diagnosed with schizophrenia. ${ }^{168}$

A third case that exemplifies this problem occurred in the Andre Lewis case. ${ }^{169}$ Lewis's case was reversed because of the following remarkable three reasons: (1) based on the trial attorney's own records, he spent only twelve hours of his time devoted to preparing for the penalty phase of the trial; (2) the attorney's admitted erroneous understanding of state law related to mitigation and (3) although funds were available, the trial attorney never had the defendant undergo psychiatric testing. ${ }^{170}$ Most pertinent to the issue of counsel admission of error, Lewis's trial attorney mistakenly thought that the mitigation related to childhood abuse and/or mental impairment would be considered an aggravating factor by the jury at the sentencing phase of the capital murder trial and that it "was not relevant under the special issues in the Texas death penalty

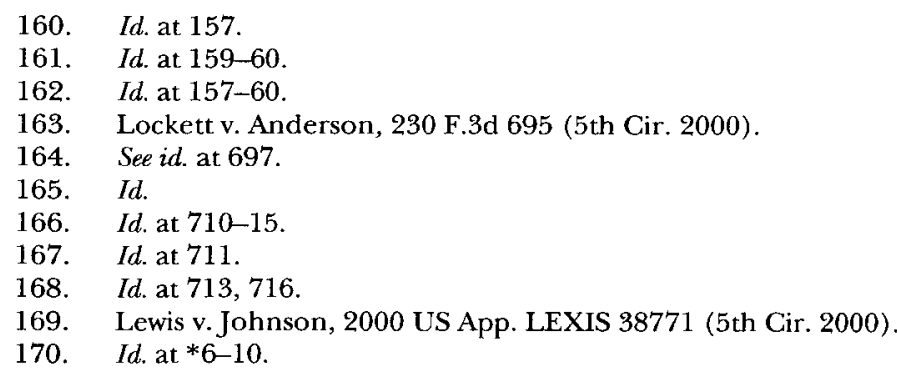


statute." ${ }^{171}$ The court ruled that this erroneous understanding of state law constituted prejudice under Strickland by not introducing the mitigating evidence that was available. ${ }^{172}$ This case also illustrates how other factors such as extremely untimely investigations and erroneous understanding of state law may contribute to a Strickland reversal.

\section{b. Misunderstanding of State Law}

Consider the Strickland reversals that focused on "counsel admission of error" related to a misunderstanding of the state law (23\% of the reversals). As previously discussed in the case of Andre Lewis, his trial attorney mistakenly thought that the mitigation related to childhood abuse and/or mental impairment would be considered an aggravating factor by the jury. ${ }^{173}$ As a result, he erroneously believed that the defendant's evidence of abuse at the sentencing phase of the capital murder trial was "not relevant under the special issues in the Texas death penalty statute." ${ }^{174}$ The court ruled that this erroneous understanding of state law constituted prejudice under Strickland as reflected in counsel's failure to introduce the mitigating evidence that was available. ${ }^{175}$

The case of Alvin Loyd similarly depicts a similar egregious error on the part of trial counsel. ${ }^{176}$ There, the defendant claimed that his defense attorney was ineffective in the penalty phase of his trial because he failed to pursue independent psychological evaluations for him. The court found that Loyd's attorney's decision was based upon a failure to understand the difference between the M'Naghten test for insanity of "mental disease or defect" and the Louisiana mitigating factor of "mental or emotional disturbance," 177 and concluded that the attorney's performance fell below professional standards. ${ }^{178}$

The state court also had found that there had been funds available for an independent psychiatric analysis of the defendant. ${ }^{179}$ The court concluded "for counsel not to have sought such an evalua-

171. Id. at *10,*14-15

172. $I d$. at $* 19$.

173. Id. at *14.

174. Id. at $* 10$.

175. Id. at *19. Lewis was subsequently resentenced to life in prison with the possibility of parole. See Email from Richard Ellis, Esq,, Lewis's appellate counsel, to authors of this Article, Jan. 21, 2019, infra note 365 (Appendix B).

176. See Loyd v. Whitley, 977 F.2d 149 (5th Cir. 1992).

177. Id. at 152.

178. $I d$.

179. Id. 
tion, where funds were available to do so, was an error which falls below the professional standards of conduct required to constitute proper representation." 180

The defendant's new habeas counsel hired psychiatrists and psychologists, who examined Loyd after his original sentencing trial, and concluded he was psychotic at the time of the murder and should have been examined more closely for organic brain damage. ${ }^{181}$ According to the judges in the Fifth Circuit, there was enough evidence proving mental disease and defect that the balance of aggravating and mitigating factors may have been different if the mental health evidence was included. ${ }^{182}$ The judgment of the district court was subsequently reversed, and the case was remanded for a new sentencing hearing. On retrial, Loyd was sentenced to life imprisonment. ${ }^{183}$

\section{c. Insignificant Amount of Time Devoted to the Case}

The issue of the lack of time devoted to an investigation was the most prevalent factor found among the reversals (46\% of the cases). In the case of Koon $v$. Cain, ${ }^{184}$ Walter J. Koon was convicted of killing his wife and her parents in Louisiana and sentenced to death. As part of his appeals, Koon argued that although he had had a year to prepare, Koon's attorney, Kevin Monahan, hired Dr. Marc Zimmerman, the psychiatric expert one day before the trial and he was only given one hour to interview Koon. ${ }^{185}$ Due to Monahan's procrastination until the last minute, Zimmerman did not have time to consult the defendant's family members or friends before testifying. ${ }^{186}$ As a result, the state's expert produced a devastating rebuttal based on the many things the defense expert failed to produce due to his lack of time to prepare (one day) and his lack of time to interview the defendant (only one hour). As cited by the court: Monahan was "unprepared" and "made no attempt... to

180. Id. Under Louisiana law, "[i]f the circumstances indicate that because of a mental disease or mental defect the offender was incapable of distinguishing between right and wrong with reference to the conduct in question, the offender shall be exempt from criminal responsibility." LSA-R.S. $\$ 14: 14$ (2017) (restating the M'Naghten rule); see also State v. Golston, 67 So. 3d 452, 466 (La. 2011).

181. Loyd, 977 F.2d at $152-56$.

182. Id. at 160 .

183. Email from John Getsinger, Esq., Loyd's appellate counsel, to authors of this Article, Jan. 20, 2019; see also Appendix B, infra, note 338 and accompanying text.

184. 277 Fed. App'x 381 (5th Cir. 2008).

185. Id. at 387 .

186. Id. at $387-88$. 
counter the state's devastating rebuttal." ${ }^{187}$ After the Supreme Court denied the state's petition for certiorari, ${ }^{188}$ Koon was subsequently sentenced to life without parole. ${ }^{189}$

Another example of a very limited investigation occurred in the case of Walbey $v$. Quarterman. ${ }^{190}$ Walbey, who had been convicted of capital murder in Texas and sentenced to death, argued on appeal his attorney did not reach an independent conclusion regarding a mitigation defense and delegated that task to an expert (Dr. Wills) who was told his role was limited to assessing future dangerousness. ${ }^{191}$ This expert admitted he spent only two hours preparing the case. ${ }^{192}$ Counsel's investigation was deemed deficient by a district court, as he only scanned several files sent to him on the defendant's background and subsequently failed to introduce evidence from several mental health professionals stating that his client had a nightmarish childhood and was borderline "mentally retarded." 193

Moreover, Dr. Wills was not retained until a week before the trial. He did not investigate mitigation, he spent very little time preparing the future dangerousness issue, and he had little time with the attorney to prepare to testify. The court also found that the defendant's psychiatric testimony by Dr. Wills "did severe damage to Walbey's case," and that, strikingly, Dr. Wills admitted to "feeling embarrassment over how poorly prepared to testify he felt:" remand, the successor District Attorney in the county where the crime took place accepted Walbey's plea to a life sentence. ${ }^{195}$

Consider also the very minimal investigation in the case of Trevino v. Davis. ${ }^{196}$ After Trevino was convicted of murder and sentenced to death, he argued that counsel failed to investigate the possibility of a Wiggins claim ${ }^{197}$ which the court ultimately ruled constituted ineffective assistance of counsel. ${ }^{198}$ The court ruled the record "shows that the minimal investigation conducted by Trevino's trial

187. Id. at 384 .

188. See Cain v. Koon, 555 U.S. 1010 (2008).

189. John Pope, Lauyer Who Fought Death Perially Dies at 90, Times-PicAYUne (Sept. 6, 2017), https://www.nola.com/news/crime_police/article_e2480b59-86be-5cbab9ff-a3697f902ef2.html.

190. 309 Fed. App'x 795 (5th Cir. 2009).

191. See id. at $797,800-01$.

192. Id. at 801 .

193. Id.

194. Id. at 804 (emphasis added).

195. See Leigh Jones, Cry for Justice: Galvestom Teacher's Murder Prompls Death Penally Debale, GALVESTON CRIME SCENE (July 19, 2018), http://www.galvestoncrimescene.com/?p=329.

196. Trevino v. Davis, 829 F.3d 328 (5th Cir. 2016).

197. See supra text accompanying notes 89-92 (discussing Wiggins v. Smith, 539 U.S. 510 (2003)).

198. Trevino, 829 F.3d at $348-49$. 
counsel here is remarkably similar to the investigation in Wiggins that the Supreme Court held to be constitutionally deficient."

When describing counsel's minimal investigation, the court stressed: "Not only did Trevino's counsel do an abysmal job of locating potential mitigation witnesses, but he failed to elicit easily obtainable information from the few interviews he conducted, most notably the whereabouts of Trevino's mother." ${ }^{200}$ In this case, Trevino's counsel presented "only one mitigation witness and no other evidence during the punishment phase." ${ }^{201}$ The one mitigation witness was Trevino's aunt, and counsel interviewed her briefly only on the day of her testimony. ${ }^{202}$ At the state habeas hearing, trial counsel testified "that he knew [Trevino's] mother had been in court-or in the courthouse-at some time before [Trevino's] trial, but that he was 'unable to get hold of her.",203

This led the circuit court to believe that there was a reasonable probability that the jury may have decided against death if they were provided with the mitigating evidence Trevino claimed should have been investigated and presented, ${ }^{204}$ concluding, “[g]iven that Trevino's life was on the line, reasonable jurists would consider the mitigation investigation conducted by his trial counsel insufficient." "To5 bolster this argument, trial counsel had "acknowledged that information regarding [the defendant's childhood], including his pre-natal exposure to alcohol, was not explored or presented as potential mitigating factors." 206

Another excellent illustration involves the case of Andre Lewis. ${ }^{207}$ The case was reversed in part because, based on the trial attorney's own records, he spent only 12 hours of his time preparing for the penalty phase of the trial (counsel had had eight months to prepare for trial). ${ }^{208}$ He called no witnesses at the guilt phase and only one witness at the punishment phase, the defendant's grandmother. ${ }^{209}$ Based upon discovery by federal habeas counsel, there were several character witnesses including the defendant's high school football coach and math teacher, his aunt, and his sister who could have testified about Lewis's abusive childhood and his cognitive

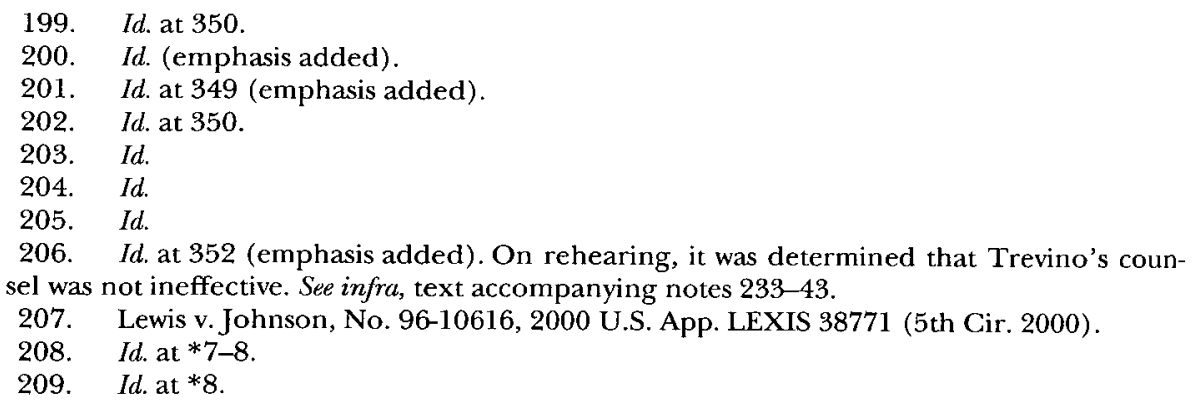


difficulties, but the attorney never contacted these character witnesses. ${ }^{210}$ The new habeas attorneys discovered that the defendant suffered severe childhood physical, psychological, and sexual abuse and experts found neurological impairments. ${ }^{211}$

\section{d. Bizarre Behavior of the Defendant}

Two of the Strickland reversals involved extremely bizarre or strange factual circumstances related to the defendant's mental health. In the case of Saldaño v. Davis, ${ }^{212}$ Victor Hugo Saldaño had been convicted of capital murder in Texas and sentenced to death. During appeals, the defendant claimed that his Sixth Amendment right to effective assistance of counsel was violated. Saldaño argued that his counsel failed to request a competency hearing despite the existence of evidence putting his mental state into question. ${ }^{21}$

The circuit court ruled in favor of Saldaño by finding his trial counsel deficient. ${ }^{214}$ The defendant had been previously diagnosed with several psychotic disorders, and his behavior in the courtroom and in jail grew more bizarre throughout the trial. ${ }^{215}$ The court ruled that this was enough reason for counsel to doubt their client's competency and should have warranted a competency hearing. ${ }^{216}$

The court also ruled that counsel's deficient performance caused prejudice to Saldaño's case, as there seemed to be a reasonable probability that the trial court would have found Saldaño incompetent to stand trial. ${ }^{217}$ Dr. Orlando Peccora, a psychiatrist who treated Saldaño at the Jester IV Psychiatric Facility of the Texas Department of Criminal Justice (TDCJ) submitted a declaration in which he diagnosed the defendant with depression which "sometimes involved psychotic ideations, hallucinations, and delusions." ${ }^{218}$ Dr. Peccora also noted the defendant's “'diminished cognitive ability' and 'diminished ability to react in emotionally appropriate fashion to events around him'” (i.e., the defendant masturbated in front of the jury during trial) although he did not believe Saldaño was incompetent. ${ }^{219} \mathrm{He}$ attributed the defendant's

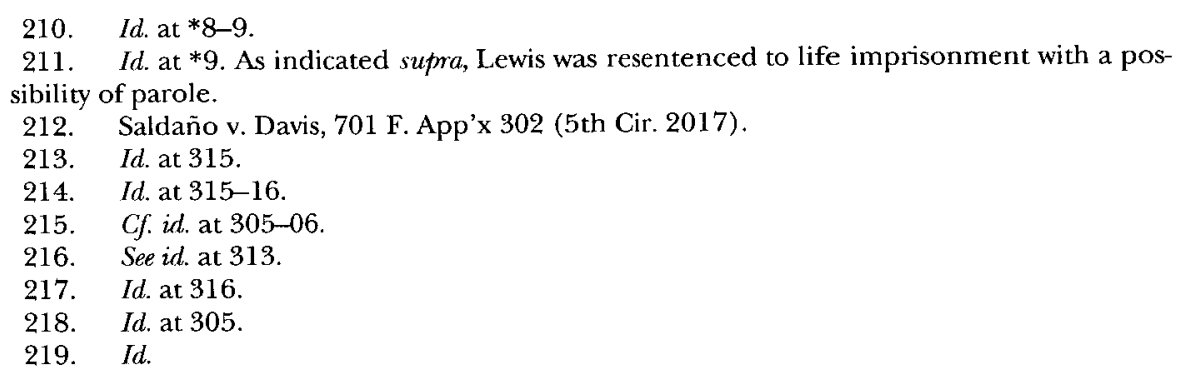


misbehavior to his mental deterioration from isolation on death row. ${ }^{220}$

In the other bizarre case, Zimmerman $v$. Cockrell, ${ }^{221}$ Kevin Lee Zimmerman had been convicted of capital murder in Texas and sentenced to death. During appeals, Zimmerman claimed that his defense attorney failed to investigate his mental health related to his competency to stand trial. ${ }^{222}$ The defendant was given a personality inventory (MMPI), and the results of that assessment indicated it was unlikely Zimmerman would be able to contribute to his defense. He also wrote threatening letters to the trial court and prosecution, demanding to be charged with capital murder. ${ }^{228}$ More specifically, the MMPI “evaluation [was] completed three weeks prior to trial and letters [the defendant] wrote to the trial court and prosecutor containing threats and a demand to be charged with capital murder." 224

The circuit court ruled that the results of the personality inventory were enough to render the defense counsel deficient, as this was a clear signal to further investigate the issue of competency. ${ }^{225}$ The court also ruled that there was an adequate chance that Zimmerman was truly incompetent to stand trial, and, therefore, this failure to investigate competence severely prejudiced his case. ${ }^{226}$ The MMPI results concluded that "it is unlikely that [the defendant] could contribute to his own defense at a legal hearing, since his behavior is inappropriate and his thoughts are illogical." 227

\section{e. Cumulative Error}

Most of the Strickland reversals involved multiple errors that were identified in the beginning of this section. ${ }^{228}$ Importantly, in some of the cases, the court mentioned these "cumulative errors" as another reason for the reversal. Notably this occurred in the Bobby Moore and the Walter Koon cases. For example, the court ruled

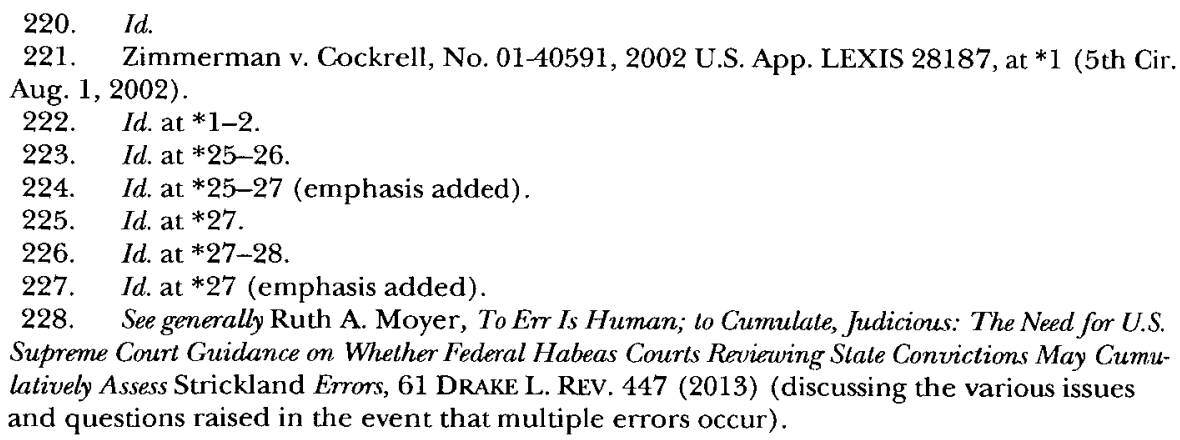


that counsel prejudiced Moore's case, as his failure to present mitigation removed any hope of convincing the jury to spare the defendant's life. ${ }^{229}$ Counsel completely failed to investigate Moore's background and offered no mitigating evidence at the punishment phase which concluded in "less than ten minutes." ${ }^{230}$ The court found that counsel's complete failure to present mitigating evidence did not make "common sense" and was unreasonable. ${ }^{231}$ Counsel should have presented mental health mitigation related to his mental development and functioning and borderline IQ to counter the damaging and misleading evidence offered by the prosecution, and the failure to do so resulted in a prejudicial death sentence for the defendant. In fact, the court concluded that trial counsel's "cumulative errors" resulted in Moore's punishment phase being unreliable. ${ }^{232}$

Moreover, in the Koon case, ${ }^{233}$ the district court found that defense counsel's conduct was deficient based upon four "crucial mistakes" which resulted in cumulative "egregious[]" error. ${ }^{234}$ The attorney failed to interview the only eyewitness to the crime, Robinson, and did not have a strategic reason for this failure; the defense attorney waited until the day before the sentencing trial to hire the mental health expert, Zimmerman; ${ }^{235}$ Monahan decided to proceed alone on the case without the aid of at least one other attorney; and he failed to properly prepare Koon to testify. ${ }^{236}$ The district court ruled that "Monahan's failure to interview Robinson, standing alone, [was] a constitutionally deficient performance; it highlighted his other missteps ... to further emphasize the egregiousness of Monahan's deficient representation" during the guilt phase of Koon's trial and "the cumulative prejudicial effort of these multiple deficiencies." district court's findings, and ruled that "Monahan's failure to interview Robinson constituted deficient performance per se" and highlighted "his last-minute hiring of Zimmerman" as "exacerbat[ing] the deficient performance." tempt to counter the state's rebuttal against the defense's expert witness, as he was thoroughly unprepared to defend his client. The

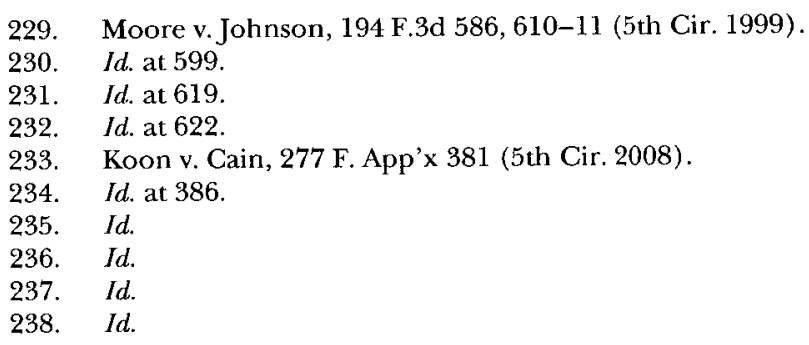


circuit court also found that defense counsel's deficient performance prejudiced Koon, as there was a reasonable probability that the jury would have found Koon guilty of a lesser offense or sentenced him to life in prison rather than death if counsel had not acted unreasonably. ${ }^{239}$

\section{f. Intellectual Disability Claims}

Consider now the performance of counsel in cases in which there was evidence of defendants' intellectual disability. There were 54 claims based on the Supreme Court's decision in Atkins $v$. Virginia $^{240}$ out of the total sample of 198 cases $(27.2 \%)$. Of the 54 claims, 20 were cases decided pre-Atkins and 34 were cases decided post-Atkins. Moreover, only 5 out of the 54 claims were successful. As a result, in 5 out of the 13 Strickland reversals (38\%), a claim of intellectual disability seemed to be a prominent factor in the court's decision to rule in favor of the defendants' ineffective assistance of counsel argument. In the five successful cases, three of the cases were decided pre-Atkins (Bobby Moore, David Wilson and Larry Jones) and two were decided post-Atkins (Anthony Pierce and Edward Busby).

The most compelling case was that of Larry Jones. ${ }^{241}$ Larry Jones was convicted and sentenced to death for a robbery-murder, under the felony-murder rule in Mississippi. The defendant argued that his counsel was ineffective for failing to present any mitigating factors at the sentencing phase of the trial. The following mitigating factors were not presented at trial and were established at the habeas hearing in the federal district court: most notably, Jones "was mentally retarded" and this fact was agreed to by the state, with an IQ "of less than 41," he was emotionally disturbed, he was seventeen at the time of committing the crime and the state did not prove he had "any intent or role in the homicide." 242 The court ruled that counsel's failure to present any mitigating factors was "professionally unreasonable." ${ }^{243}$ In addition, this failure was "prejudicial to the defendant in that there is a reasonable probability that had this evidence been presented, the jury would have concluded that death was not warranted." ${ }^{244}$

239. Id. at $388-89$.

240. Atkins v. Virginia, 536 U.S. 304 (2002) (finding the execution of a person with mental retardation, as it was then characterized, to be cruel and unusual punishment).

241. Jones v. Thigpen, 788 F.2d 1101 (5th Cir. 1986).

242. $I d$. at 1103 (emphasis added).

243. Id

244. Id. 
In sum, after careful examination of the thirteen Strickland "reversals," ${ }^{245}$ the most significant observation is that the reversals are so rare because the case circumstances need to be so exceptionally shocking for the court to grant relief. Three findings stand out: (1) on post-conviction, trial attorneys need to admit unprofessional errors in order to rebut the state's theory of a "strategic decision" under the Strickland performance standard; (2) in more than half of the reversals, trial counsel spent an exceptionally insignificant amount of time on the investigation (typically, the investigation lasted for hours or at most a day or two) and (3) in all of the reversals, multiple egregious errors seemed to occur, which points to the reluctance of the court in the Fifth Circuit to grant reversals or certificates of appealability [COA] on this issue. For example, among the entire sample of Strickland claims related to mental health, only $6.5 \%(13 / 198)$ were successful.

\section{3. "Back Stories"}

Again, it is crucial to consider what actually happened in each of these cases. As noted above, we were able to determine the current status of all but one of the thirteen cases in question. And, where information was available, ${ }^{246}$ this is what we learned:

- One defendant was executed; ${ }^{247}$

- One was re-sentenced to death, following a Supreme Court decision vacating the decision discussed here; subsequently, that re-sentence was also vacated; ${ }^{248}$

- Three other defendants are still on death row; in one of these cases, a petition for an en banc hearing before the Fifth Circuit is pending; ${ }^{249}$

245. We use quotation marks here to drive home the point that these decisions rarely resulted in any sort of ultimate relief for the defendants. See infra text accompanying notes $243-48$.

246. Some of this came from subsequent published opinions, some from press accounts, and some from other web pages. See Appendix B.

247. See U.S.A. Executions - 1977-Present, DEATHPENALTyUSA, http:/ / deathpenaltyusa.org/usa/index-Z.htm (last visited Nov. 19, 2019); Zimmerman v. Cockrell, No. 01-40591 2002 WL 32833097 (5th Cir. Aug. 1, 2002). Zimmerman was executed two years after that decision.

248. See Moore v. Johnson, 194 F.3d 586 (5th Cir. 1999). Moore was subsequently resentenced to a term of life imprisonment. See Ex parle Moore, No. WR-13,374-052019 WL 5778063 (Tex. Ct. Crim. App. Nov. 6, 2019), as discussed in Jolie McCullough, Bobby Moore's Death Sentence Is Changed to Life in Prison afler Lengthy Courl Fights over Intellectual Disability, TEx. Trib. (Nov. 6, 2019), https://www.texastribune.org/2019/11/06/texas-bobbymoore-death-row-life-in-prison-intellectual-disability/.

249. See Saldaño v. Davis, 701 F. App'x 302 (5th Cir. 2017); Busby v. Davis, 677 F. App'x 884 (5th Cir. 2017); Trevino v. Davis, 829 F.3d 328 (5th Cir. 2016). 
- Two defendants had their death sentences commuted; $;^{250}$

- Five defendants were resentenced to life without parole, ${ }^{251}$ and

- There is no information available about later developments in one case. ${ }^{252}$

On the merits, at subsequent rehearings, just two of this cohort of defendants were found to not have received ineffective assistance. ${ }^{259}$ These were the only cases in which the question of adequacy of counsel was further explored, and in both-the case of Carlos Trevino and the case of Edward Lee Busby-the Fifth Circuit ultimately found, after further remand, that there was no Strickland error.

In Trevino, trial counsel's alleged failure to adequately investigate and present certain mitigating evidence at sentencing was found to not prejudice petitioner, and thus was not ineffective assistance. ${ }^{254}$ In reality, Trevino's lawyer's work was appalling. ${ }^{255}$ When describing counsel's minimal investigation, the court, in its initial opinion, noted: "Not only did Trevino's trial counsel do an abysmal job of locating potential mitigation witnesses, but he failed to elicit easily obtainable information from the few interviews he conducted, most notably the whereabouts of Trevino's mother." 256

In this case, Trevino's counsel presented "only one mitigation witness and no other evidence during the punishment phase." ${ }^{257}$ The one mitigation witness was Trevino's aunt, and he interviewed her briefly only on the day of her testimony. ${ }^{258}$ At the state habeas hearing, trial counsel testified "that he knew [the defendant's] mother had been in court-or at least in the courthouse at some

250. See Lewis v. Johnson, No. 96-10616 2000 WL 35549205 (5th Cir. Dec. 21, 2000); Walbey v. Quarterman, 309 F. App'x 795 (5th Cir. 2009).

251. Wilson v. Butler, 813 F.2d 664 (5th Cir. 1987); Lockett v. Anderson, 230 F.3d 695 (5th Cir. 2000); Loyd v. Whitley, 977 F.2d 149 (5th Cir. 1992); Pierce v. Thaler, 355 F. App'x 784 (5th Cir. 2009); Koon v. Cain, 77 F. App'x 381 (5th Cir. 2008). In one of these cases $($ Loyd $)$, a jury imposed the life sentence and new counsel had to hire a bodyguard to protect them from angry townspeople. Email from John Getsinger, Esq., Loyd's appellate counsel, to authors (Jan. 20, 2019) (Appendix B).

252. Jones v. Thigpen, 788 F.2d 1101 (5th Cir. 1986). There are no other reported cases, and it was impossible to find out anything about this case on the internet. Defense counsel has subsequently died, and the state's attorney did not answer our email.

253. Trevino v. Davis, 829 F.3d 328 (5th Cir. 2016); Busby v. Davis, 677 F. App'x 884 (5th Cir. 2017); see supra text accompanying notes 254-68.

254. Trevino, 861 F.3d 545 (5th Cir. 2017), cert. denied, 138 S. Ct. 1793 (2018).

255. See Trevino, 829 F.3d at 350 (likening the factual circumstances to those that the Supreme Court confronted in Wiggins v. Smith, 539 U.S. 510 (2003)); see also supra text accompanying notes 90-92 (discussing the factual circumstances in Wiggins).

256. Trerino, 829 F.3d at 350 (emphasis added).

257. Id. at 349 (emphasis added).

258. Id. at 350 . 
time before [Trevino's] trial, but that he was 'unable to get hold of her." "259 The attorney did not interview many mitigation witnesses and failed to look into his client's diagnosis of Fetal Alcohol Spectrum Disorder. ${ }^{260}$

Remarkably, in an affidavit by a defense expert retained for the federal habeas hearing, Trevino's trial counsel conceded that little work was done on mitigation "as 'mitigation experts were not used very much at the time of the trial." ${ }^{261}$ Of course, by the time of Trevino's trial-sometime after June 1996 when the crime in question took place - the Supreme Court had already mandated mitigation review in multiple cases, dating back to some twenty years prior. ${ }^{262}$ In fact, writing some years prior to Trevino's trial, one of the authors (MLP) had written, "Contemporary death penalty jurisprudence requires the sentencing authority to consider any relevant mitigating evidence that a defendant offers as a basis for a sentence less than death." 263 And, as noted, Trevino remains on death row. ${ }^{264}$

Busby argued unsuccessfully to the Fifth Circuit that his lawyer failed to uncover or present multiple pieces of mitigating evidence to the jury:

(1) Busby was abandoned by his mother the first two years of his life and instead lived with his grandmother; (2) Busby and his sisters were abused by their mother and father and grew up in a violent household; (3) Busby's hometown was segregated and racially-biased; (4) Busby grew up in extreme poverty; (5) Busby was "slow" and suffered from intellectual disability and mental illness; (6) Busby was easily manipulated by women; and (7) Busby was addicted to crack, marijuana, and alcohol. ${ }^{265}$

\footnotetext{
259. Id.

260. Id. at 352 .

261. Id.

262. See, e.g., Eddings v. Oklahoma, 455 U.S. 104, 114 (1982); Lockett v. Ohio, 438 U.S. 586, 604 (1978); Penry v. Lynaugh, 492 U.S. 302, 328 (1989).

263. Perlin, Sanist Lives, supra note 3, at 243.

264. See Carlos Trevino \#999235, DEATHROW-USA, http://deathrowusa.com/carlos_trevino.htm (last visited Nov. 1, 2019).

265. Busby v. Davis, 892 F. 3d 735, 760 (5th Cir. 2018). ("Busby asserted that his mother did not obtain prenatal healthcare when pregnant with him. According to Busby's sisters, Busby's mother was physically violent with her children. She would 'whoop' them with a 'belt, switch, shoe or extension cord.' His mother also physically attacked Busby's father and another male with whom she lived after Busby's father left. Her children often witnessed the altercations. In one incident, Busby's mother attempted to run over the man with whom she lived while Busby was in the vehicle with her. Busby's mother also stabbed a man with whom she lived in his hands with a butcher knife when he was attempting to deflect her attacks. One sister claimed that Busby's mother did not love Busby and would tell him that he was
} 
Notwithstanding this evidence-and more ${ }^{206}$ - the Fifth Circuit concluded that this new mitigation evidence, considered with that adduced at trial, "does not outweigh the State's aggravation evidence such that 'there is a reasonable probability that at least one juror' would have recommended a life sentence," ${ }^{267}$ and thus concluded that he was "therefore not prejudiced by his trial counsel's allegedly deficient mitigation investigation."

There is no coherence in the dispositional outcomes of the other cases, but the most likely denouement (via multiple routes) was a plea of guilty in exchange for a life-without-parole (LWOP) sentence or the commutation of the death sentence. This was what happened in Lockett, Cain and Pierce (LWOP plea) as well as in Walbey and Lewis (commutation). There has been one execution (Zimmerman). In the Moore case, the Supreme Court struck down the Texas Appeals Court ruling in 2017 and sent the case back for further review utilizing a test based on more current medical standards. ${ }^{269}$ Although Moore's prosecutor requested the defendant's sentence be changed to life in prison, the Court of Criminal Appeals again rejected this plea, ruling that Moore was not intellectually disabled under either standard ${ }^{270}$ The Supreme Court granted certiorari again, and once more held that the Texas court was in error in determining that Moore was not intellectually disa-

'just like [his] sorry-ass daddy.' They also described Busby's father as a 'drunk' and stated that Busby's 'dad would hit him with anything' when he was inebriated. One sister said that they were poor, Busby and his siblings were 'hungry sometimes,' and the water was once 'cut off for about a week.' Both sisters described Busby as slow, irresponsible, and unhygienic." ).

266. See id. at 761 (noting that a clinical psychologist diagnosed Busby with bipolar disorder).

267. Id. (citing Wiggins v. Smith, 539 U.S. 510,537 (2003)).

268. Id. Busby's petition for an en banc rehearing is currently pending before the Fifth Circuit. Email from David Dow, Busby's appellate counsel, to MLP (Jan. 20, 2019) (Appen$\operatorname{dix} B)$.

269. See Moore v. Texas, 137 S. C. 1039 (2017) (striking down Texas's schemata for de termining if a defendant was sufficiently intellectually disabled for Eighth Amendment violations). See, e.g., Alexander H. Updegrove, Michael S. Vaughn \& Rolando V. del Carmen, Inlellectual Disability in Capital Cases: Adjusting Slate Slalules After Moore v. Texas, 32 Notre DAME J.L. ETHICs \& PUB. POL'Y 527 (2018); Austin Holler, Note, Moore v. Texas and the Ongoing National Comsensus Siruggle Between the Eighth Amendment, the Death Penalty, and the Definition of Intellectual Disability, 50 LOY. U. CHI. L. J. 415 (2018).

270. See Ex Parte Moore, 548 S.W.3d 552 (Tex. Crim. App. 2018), reversed, 139 S. Ct. 666 (2019); see also Jolie McCullough, Texas Still Doesn't Have a Law on Intellectual Disability and the Death Penally. Will That Change This Year? TeXas Triв. (Feb. 1, 2019),

https:/ / www.texastribune.org/2019/02/01/texas-legislature-death-penalty-intellectualdisability/ (revealing that Texas never statutorily created standards in accordance with the Supreme Court's 2017 decision). 
bled. ${ }^{271}$ Subsequently, the Texas Court of Criminal Appeals resentenced Moore to a term of life imprisonment. ${ }^{272}$

\section{Those Affirmances with No Mitigation}

Trial counsel failed to present any mitigating evidence in 19 out of the 198 cases $(9.6 \%$ of the sample). In two of these cases, there was a successful Strickland claim and reversal (Larry Jones and Carl Lockett). However, in the 17 affirmances, the most common justification for upholding the death sentence was the court ruling that counsel made a "strategic decision" not to present the evidence because it would have been seen as "double-edged" and would have been used by the jury as aggravating, thus supporting a conclusion that the defendant was a future danger. ${ }^{273}$ By way of example, these cases illustrate this important finding:

1) In Garza v. Thaier, ${ }^{274}$ defense counsel conducted an investigation into mitigation, but there was a strategic decision, with Garza's consent, not to introduce any mitigation because of a fear that on cross-examination the defendant's prior record would be exposed. The district court concluded that the state habeas court "reasonably found that trial counsel made a well-supported strategic decision to forgo the presentation of mitigating evidence. $^{275}$

2) In Cannon v. Johnson, ${ }^{276}$ Cannon's attorney presented no mitigation at the second trial. At the first trial, mitigation was presented which resulted in rebuttal evidence including evidence of future dangerousness by Dr. James Grigson. ${ }^{277}$ At the second trial, the attorneys ar-

271. Moore, 139 S. Ct. at 672. There was no discussion of the Strickland issues in this opinion. The most recent decision in Moore has since been cited favorably in one case outside of the Fifth Circuit. See Commonwealth v. Cox, 204 A.3d 371, 378 n.8 (Pa. 2019).

272. Ex parte Moore, No. WR-13,374-052019 WL 5778063 (Tex. Ct. Crim. App. Nov. 6, 2019).

273. Vaca v. State, 314 S.W.3d 331, 336 n.4, 337 (Mo. 2010) ("Commentators have noted the double-edged nature of such evidence, finding that many jurors hold a presumption of an absolute linkage between mental illness and dangerousness.") (quoting Perlin, Sanist Lives, supra note 3, at 258-59).

274. 487 F. App'x 907 (5th Cir. 2012).

275. Id. at 911 (emphasis added).

276. 134 F.3d 683 (5th Cir. 1998).

277. Dr. Grigson was colloquially known as the "killer shrink" who operated "at the brink of quackery." See George Dix, The Death Penalty, "Dangerousness," Psychialric Testimony, and Professional Ethics, 5 AM. J. CRIM. L. 151, 172 (1977); David L. Faigman, To Have and Have Not: Assessing the Value Of Social Science to the Law as Science and Policy, 38 EMORY L.J. 1005, 1077 n.268 (1989); Perlin, IIalf-Wracked, supra note 114, at 28; see also Michael L. Perlin, Therapeu- 
gued that they strategically chose not to present any mitigation to avoid rebuttal witnesses and a replay of the first trial. As a result, the court upheld the strategy as reasonable.

3) In Gates v. Davis, ${ }^{278}$ the defense did not present any mitigating evidence at the punishment phase of the trial. The defendant's attorney stated "to the trial court that they had made a diligent effort to contact a couple of cousins, but had been unable to locate them." ${ }^{279}$ The defendant argued that no witnesses were called to testify because his "defense lawyers never tried to locate any or make any investigation of his early life experiences." 280 The specific mitigation the defendant argued included: evidence that the defendant suffered from fetal alcohol syndrome, a poor upbringing, childhood neglect, sexual assault, and mental difficulties. ${ }^{281}$ The state countered that the defendant never presented this claim in state court and therefore the court must presume the witnesses were unwilling to cooperate or that trial counsel made a strategic decision not to present mitigating evidence.

4) In Ladd v. Cockrell, ${ }^{282}$ no mitigation was presented at the sentencing phase. There was evidence that the defendant had a low IQ score and the defendant was diag-

tic Jurisprudence: Understanding the Sanist and Pretextual Bases of Mental Disability Law, $20 \mathrm{~N}$. EnG. J. Crim. \& CiV. Confinement 369, 380 (1994) (explaining that Grigson testified "in defiance of all existing professional ethical guidelines").

Grigson "regularly testified fraudulently on behalf of the state at the penalty phase of death penalty cases, even afler he lost his license to practice psychialry, using, in virtually every case, 'junk science' as the basis of his opinions." Michael L. Perlin, "Your Corrupt Ways Had Finally Made You Blind": Prosecutorial Misconduct and the Use of "Elhnic Adjustments" in Death Penally Cases of Defendants with Intellectual Disabilities, 65 AM. U.L. REv. 1437, 1440 (2016) [hereinafter Perlin, Comipt Ways]; Marc Sageman, Challenging the Admissibility of Mental Expert Tesimony, 13 PRAC. LITIGATOR 7, 15 (2002) (characterizing Grigson as "notorious").

Grigson was decertified by the American Psychiatric Association and the Texas Society of Psychiatric Physicians in 1995, but he continued to testify in death penalty proceedings for years after that date. See Michael L. Perlin, "Merchants and Thieves, Hungry for Power": Proseculorial Misconduct and Passive Judicial Complicity in Death Penalty Trials of Defendants with Mental Disabilities, 73 WASH. \& LEE L. REV. 1501, 1528 (2016) (hereinafter Perlin, Merchants). Grigson testified in cases included in the cohort studied here. See Johnson v. Cockrell, 306 F.3d 249 (5th Cir. 2002); see generally Gardner v. Johnson, 247 F.3d 551, 556 n.6 (5th Cir. 2001) (explaining the circumstances behind Dr. Grigson's loss of his license).

278. Gates v. Davis, 660 F. App'x 270 (5th Cir. 2016).

279. Id. at 272 .

280. Id.

281. See id. at 275-76.

282. Ladd v. Cockrell, 311 F.3d 349 (5th Cir. 2002). 
nosed with "mental retardation" as a child. ${ }^{283}$ The court ruled against the defendant's ineffective assistance of counsel argument because the evidence would have been "double edged" as a future danger plus the crime was "extremely horrific and the evidence of guilt overwhelming." deficient performance but that there was no prejudice, a finding affirmed by the Fifth Circuit, due to the "horrific" nature of the crime, leading it to conclude that the evidence of his future dangerousness was "overwhelming." 285

5) In Williams $v$. Cain, ${ }^{286}$ the trial court had found after an evidentiary hearing that the attorney's "failure to present evidence concerning the defendant's alleged borderline retardation was not deficient because his attorney (Bonnette) was aware that the state could produce evidence from three experts to rebut any such testimony." 287 On appeal, the defendant repeated his state court arguments and also argued that his attorney was ineffective for failing to investigate his background of childhood abuse and his "long history of mental problems and that he was borderline retarded." ${ }^{288}$

Here, the Fifth Circuit ruled that a failure to present a mitigation case is not per se ineffective assistance of counsel, ${ }^{289}$ citing Stringer $v$. Jackson, ${ }^{290}$ a decision subsequently vacated by the Supreme Court seven years before the Circuit decided Williams' case. ${ }^{291}$

283. Id. at 360. Ladd was decided some four months after the Supreme Court's decision in Atkins v. Virginia, 536 U.S. 304 (2002) (finding the execution of a person with mental retardation to be cruel and unusual punishment).

284. Id. at 360 .

285. Id.

286. Williams v. Cain, 125 F.3d 269 (5th Cir. 1997).

287. Id. at 277. Of course, this is not fear of testimony as to dangerousness, but rather, fear that another expert will come in and defense counsel would be unable to appropriately cross-examine him.

288. Id.

289. Id. at 278. The defendant's attorney arranged for the defendant to be evaluated by a clinical psychiatrist, Dr. Strother Dixon. Id. at 277-78. Based on Dr. Dixon's report, the Court concluded that the defendant's arguments concerning his mental problems and alleged "borderline retardation" to be "entirely unavailing." Id. at 278. Williams, of course, was decided five years before the U.S. Supreme Court's Atkins decision. See Atkins v. Virginia, 536 U.S. 304 (2002).

290. Stringer v. Jackson, 862 F.2d 1108, 1116 (5th Gir. 1988).

291. See Stringer v. Black, 494 U.S. 1074 (1990). 


\section{Conclusions and Findings}

According to Professor Janet Moore, after Strickland, "the substantive meaning of the Sixth Amendment right to counsel turns on real-world practices and the resources available to support highquality attorney performance." ${ }^{292}$ The data demonstrate, beyond doubt, that the Strickland test has failed miserably as an aspirational bulwark, and that, due to inadequate counsel, defendants with serious mental disabilities continue to have death sentences upheld and, in some cases, be executed. To say that Strickland ultimately protects defendants is the ultimate pretext.

There are multiple reasons for this, but certainly the sanist attitudes of fact-finders and their reliance on false "ordinary common sense" are among the key causes. Consider the recent research of Professors Emily Shaw and her colleagues that shows that a significant number of mock jurors (selected from a pool of venireeligible jurors) simply chose to "not follow the law which clearly stated that intellectually disabled individuals cannot be sentenced to death." ${ }^{293}$ Similarly, a thoughtful study of cases involving defendants with anti-social personality disorder (ASPD) concludes, in the context of "ordinary common sense," that juries and judges alike are persuaded by the lay stereotypes involving remorse."294 "Despite the Supreme Court's clear mandate to avoid the use of lay stereotypes, ${ }^{295}$ the lay stereotypes of ASPD continue to prejudice capital defendants." ${ }^{296}$

It goes without saying that the Fifth Circuit complicitly endorses these biases and prejudices in the vast majority of its decisions in this area of law.

292. Janet Moore, Isomomy, Austerity, and the Right to Choose Counsel, 51 IND. L. REV. 167, 174 (2018). Professor Moore is one of the leaders of the Indigent Defense Research Association. See Andrew L.B. Davies \& Janet Moore, Critical Issues and New Empirical Research in Public Defense: An Introduction, 14 OHIO ST. J. CRIM. L. 337 (2019).

293. Emily V. Shaw, Nicholas Scurich \& David L. Faigman, Intellectual Disability, the Death Penalty, and Jurors, 58 JURIMETRICS 437, 456 (2018).

294. Dale F. Ogden, Executed for Their Disabilities, 39 U. LA VERNE L. REV, 304, 319 (2018). On the impact of juror perceptions of remorse in death penalty cases (and how those perceptions may be wildly inaccurate, especially in cases in which defendants are medicated at their trials), see Perlin, Merchanls, supra note 277, at 1531 (discussing Justice Kennedy's concurrence in Riggins v. Nevada, 504 U.S. 127, 142-44 (2002)); William Geimer \& Jonathan Amsterdam, Why Jurors Vote Life or Death: Operative Factors in Ten Florida Dealh Penally Cases, 15 AM. J. CRIM. L. 1, 51-53 (1988).

295. See Moore v. Texas, 137 S. Ct. 1039, 1052 (2017).

296. Ogden, supra note 294 , at 320 . 


\section{THERAPEUTIC JURISPRUDENCE ${ }^{297}$}

\section{A. Its Meaning}

Therapeutic jurisprudence (TJ) recognizes that, as a therapeutic agent, the law can have therapeutic or anti-therapeutic consequences. ${ }^{298}$ It asks whether legal rules, procedures, and lawyer roles can or should be reshaped to enhance their therapeutic potential while not subordinating due process principles. ${ }^{299}$ Professor David Wexler clearly identifies how the inherent tension in this inquiry must be resolved: the law's use of "mental health information to improve therapeutic functioning [cannot] impinge upon justice concerns. ${ }^{300}$ As one of the authors (MLP) has written elsewhere, "An inquiry into therapeutic outcomes does not mean that therapeutic concerns 'trump' civil rights and civil liberties." 301 Therapeutic jurisprudence "look[s] at law as it actually impacts people's lives," 302 and TJ supports "an ethic of care." ${ }^{.03}$ It attempts to bring about healing and wellness, ${ }^{304}$ and to value psychological health. ${ }^{305}$

In an earlier article about prosecutorial misconduct in death penalty cases, one of the authors (MLP) considered that issue in the context of therapeutic jurisprudence, and said this:

As stated flatly by Judge Juan Ramirez and Professor Amy Ronner, "the right to counsel is ... the core of therapeutic

297. This section is largely adapted from Michael L. Perlin, "I've Gol My Mind Made Up": How Judicial Teleology in Cases Involving Biologically Based Evidence Violales Therapeutic Jurisprudence, 24 CARD. J. EQUAL RTS. \& SOC. JUST. 81, 93-95 (2018) [hereinafter Perlin, Mind Made $U p]$; see also Michael L. Perlin \& Alison J. Lynch, "In the Wasteland of Your Mind": Criminology, Scientific Discoveries and the Criminal Process, 4 VA. J. CRIM. L. 304 (2016). Further, it distills the work of one of the authors (MLP) over the past twenty-seven years, beginning with Michael L. Perlin, What Is Therapeutic Jurisprudence?, 10 N.Y.L. SCH. J. HUM. RTS. 623 (1993). See generally on the development of the doctrine of therapeutic jurisprudence, Michael L. Perlin, "Have You Seen Dignity?": The Slony of the Development of Therapeutic Jurisprudence, 27 U.N.Z. L. REV. 1135 (2017); Michael L. Perlin, "Changing of the Guards": David Wexler, Therapeutic Jurisprudence, and the Transformation of Legal Scholarship, 69 INT'LJ. L. \& PSYCHIATRY 3 (2019).

298. Perlin, supra note 139 , at 912.

299. Perlin, supra note 113 , at 751 .

300. David B. Wexler, Therapeutic Jurispmedence and Changing Concepts of Legal Scholarship, 11 BeHAV. SCI. \& L. 17, 21 (1993).

301. Michael L. Perlin, A Law of Healing, 68 U. CIN. L. REv. 407, 412 (2000).

302. Bruce J. Winick, Foreword: Therapentic Jurisprudence Perspectives on Dealing with Victims of Crime, 33 Nova L. REV. 535, 535 (2009).

303. Perlin, Mind Made Up, supra note 297, at 94 (quoting, in part, Bruce J. Winick \& David B. Wexler, The Use of Therapeutic Jurisprudence in Latv School Clinical Education: Transforming the Criminal Law Clinic, 13 CLINICAL L. REV. 605, 605-07 (2006)).

304. Id. (citing Bruce Winick, A Therapeulic Jurispmudence Model for Civil Commilmenl, in INVOLUNTARY DETENTION \& THERAPEUTIC JURISPRUDENCE: INTERNATIONAL PERSPECTIVES ON Civil Commrtment 23, 26 (Kate Diesfeld \& Ian Freckelton eds., 2003)).

305. Id. 
jurisprudence." 306 "Any death penalty system that provides inadequate counsel and that, at least as a partial result of that inadequacy, fails to insure that mental disability evidence is adequately considered and contextualized by death penalty decision-makers, fails miserably from a therapeutic jurisprudence perspective." If counsel in death penalty cases fails to meet constitutional minima, it strains credulity to argue that such a practice might comport with TJ principles. TJ is the perfect mechanism "to expose [the law's] pretextuality" because this pretextuality is clear in the death penalty context. ${ }^{307}$

Well over twenty years ago, one of the authors (MLP) concluded that "any death penalty system that provides inadequate counsel and that, at least as a partial result of that inadequacy, fails to insure that mental disability evidence is adequately considered and contextualized by death penalty decision-makers, fails miserably from a therapeutic jurisprudence perspective." ${ }^{308}$ Sadly, little has been written since about the relationship between $\mathrm{TJ}$ and the death penalty. ${ }^{309}$ Some twenty years ago, the late Bruce Winick argued persuasively that $\mathrm{TJ}$ prohibited the execution of seriously mentally ill offenders as that could not adequately serve the goals of retribution and deterrence. ${ }^{310}$ More recently, and from a very different perspective, Cynthia Adcock-a law professor who spent thirteen years representing death penalty defendants-focused on

306. Juan Ramirez Jr. \& Amy D. Ronner, Voiceless Billy Budd: Melville's Tribute to the Sixth Amendment, 41 CAL. W. L. REv. 103, 119 (2004).

307. Perlin, Merchants, supra note 277, at 1542 (quoting, in part, Perlin, Executioner's Face, supra note 3, at 235; Michael L. Perlin, "Things Have Changed": Looking at Non-Institutional Mental Disability Law Through the Sanism Filter, 46 N.Y.L. SCH. L. Rev. 535, 544 (2003)). We agree completely with forensic psychologist Kathy Faulkner Yates, who has urged the use of therapeutic jurisprudence as a "diagnostic tool to identify the malignant way that pretextuality poisons forensic and judicial relationships." Kathy Faulkner Yates, Therapeutic Issues Associated with Confidentiality and Informed Consent in Forensis Evaluatioms, 20 NEW ENG. J. CRIM. \& CIV. CONFINEMENT 345, 357-58 (1994).

308. Perlin, Executioner's Face, supra note 3, at 235. David Wexler and Bruce Winick foresaw this nearly thirty years ago. See Therapeutic Jurisprudence as a New Approach to Mental Health Law Policy Analysis and Research, 45 U. MLAMI L. REV. 979 (1991) (applying TJ to cases involving incompetent death row inmates).

309. For an important recent international lawfocused article, see Muhammad Amir Munir, Judging in a Therapeutic Way: TJ Audit of Juvenile, Probation and Criminal Procedure Law in Pakistan with Reference to Therapeutic Design and Therapeutic Application of Law, in THE RESPONSIVE JUDGE 241, 248 (Tania Sourdin et al eds., 2018) ("If the legal actors are not friendly to TJ practices as reflected in [Pakistani statutory law] there is a chance that a child may suffer the death penalty through no fault of their own.").

For another consideration of the death penalty and TJ in the context of family survivors, see Marilyn Peterson Armour \& Mark S. Umbreit, Assessing the Impact of the lltimate Penal Sanction on Homicide Survivors: A Two Slate Comparison, 96 MARQ. L. REV. 1 (2012).

310. Bruce Winick, The Supreme Court's Evolving Death Penalty Jurisprudence: Severe Mental Illness as the Next Frontier, 50 B.C. L. REV. 785, 854-58 (2009). 
the "psychological devastation caused by the death penalty on those who the lawmakers do not intend to be the target of death penalty laws." 311 But there is so much more to consider.

\section{B. In the Context of These Cases}

It is fatuous to even consider whether the therapeutic principles to which the creators of TJ have aspired ${ }^{312}$ are part of either the trials of the defendants in this cohort of cases or the actions by counsel. Certainly, "socio-psychological insights into the law and its application" $" 313$ are utterly lacking, as is any shred of evidence of a "commitment to dignity." 314 The caselaw is totally bereft of those TJ-required fair process norms such as a meaningful right to counsel that "operate as substantive and procedural restraints on state power to ensure that the individual suspect is treated with dignity and respect." $\$ 15$

For one example, prosecutors who call expert witnesses-such as Dr. Grigson ${ }^{316}$-knowing that the "scientific bases" of the experts' testimony are worthless, baseless (perhaps, at this point in time, fraudulent), and pretextual, ${ }^{317}$ are similarly "invalidat[ing] the legitimacy of the proceedings in question." As one of the authors (MLP) has stated elsewhere, "our entire capital punishment system

311. Cynthia F. Adcock, The Collateral Anti-Therapeutic Effects of the Death Penalty, 11 FLA. COASTAL L. REv. 289, 293 (2010); see David C. Yamada, Therapeutic Jurispmedence and the Praclice of Legal Scholarship, 41 U. MEM. L. REv. 121, 138-39 (2010) (discussing Adcock's work, and noting that Adcock "reminds us of emotional consequences of law and legal systems that are all too easy to ignore").

312. See, e.g., Janet Gilbert et al., Applying Therctpentic Principles to a Family-Focused Juvenile Justice Model (Delinquency), 52 ALA. L. Rlv. 1153 (2001).

313. Ian Freckelton, Therapeulic Jurisprudence Misunderstood and Misrepresented: The Price and Risks of Influence, 30 T. JEFFERSON L. REV. 575, 576 (2008).

314. Michael L. Perlin, "Yonder Stands Your Orphan with His Gun": The International Human Rights and Therapeutic Jurisprudence Implicatioms of Juvenile Punishment Schemes, 46 TEXAS TeCh L. Rev. 301, 333 (2013) (citing BruCE J. Winick, Civil Commitment: A Therapeutic JURISPRUdeNCE MODEL 161 (2005)).

315. Michael L. Perlin \& Naomi M. Weinstein, "Friend to the Marlyr, a Friend to the Woman of Shame": Thinking About the Law, Shame and Humiliation, 24 SO. CAL. REV. L. \& SOC. JUST. 1, 12 (2014) (quoting, in part, Peter Arenella, Rethinking the Functions of Criminal Procedure: The Warren and Burger Courts' Competing Ideologies, 72 GEO. L.J. 185, 200 (1983)).

316. See Cannon v. Johnson, 134 F.3d 683, 686-87 (5th Cir. 1998), discussed supra text accompanying note 276. See also, e.g., Little v. Johnson, 162 F.3d 855, 858 (5th Cir. 1998) (in which counsel did not introduce any rebuttal psychiatric testimony); Moody v. Johnson, 139 F.3d 477, 484 (5th Cir. 1998) ("We also note that even if Dr. Grigson's testimony might have been misleading there is not a reasonable likelihood that its correction would have affected the jury's verdict.").

317. See Perlin, Half-Wracked, supra note 114, at 27-28 (discussing Charles M. Sevilla, AntiSocial Personality Disorder: Justification for the Death Penalty?, 10 J. CoNTEMP. LEGAL Issues 247, 259-61 (1999)).

318. Perlin, Merchants, supra note 277, at 1542. 
mocks those principles of $\mathrm{TJ}$ that we must embrace if we are to have a coherent and legitimate criminal procedure system." ${ }^{319}$ These Fifth Circuit cases are squarely part of the system's incoherence and illegitimacy.

\section{CONCLUSION}

The story of how the Fifth Circuit has dealt with Strickland appeals in cases involving defendants with mental disabilities facing the death penalty is bizarre and frightening. In virtually all cases, Strickland errors-often egregious errors-were ignored, and in over a third of the cases in which they were acknowledged, defense counsel had confessed error. ${ }^{320}$ Regularly, this Court affirmed convictions (in multiple cases leading to sanctioned executions) ${ }^{321}$ in cases where counsel introduced no mitigating evidence, ${ }^{322}$ failed to retain mental health experts, ${ }^{323}$ and failed to read mental health records. ${ }^{324}$ In the aggregate, the Fifth Circuit regularly and consistently mocked the idea of adequate and effective counsel.

Making a grim picture even grimmer, in that small category of reversals, remands, or court of appeals grants, at least one defendant has since been executed, ${ }^{325}$ and, as far as our research could determine, ${ }^{326}$ only one stands even the likelihood of ever being paroled. ${ }^{327}$

We have known since soon after Strickland was decided that most defendants in the circumstances of these defendants (facing the death penalty and with a mental disability)—especially in jurisdictions where there were no dedicated offices to provide representation in such cases ${ }^{328}$-received sub-standard representation. That is

319. Id.; see also Perlin, Corrupt Ways, supra note 277, at 1457 (asking, from a TJ perspective, for a "serious reevaluation of the roles of expert witnesses in testifying to 'future dangerousness" in death penalty cases.").

320. See supra text accompanying notes 158-70.

321. See infra app. A (6).

322. See supra text accompanying notes $250-67$.

323. See app. A (4). See Zimmerman v. Cockrell, No. 01-40591, 2002 U.S. App. LEXIS 28187, at *1 (5th Cir. Aug. 1, 2002).

324. See Zimmerman, 2002 U.S. App. LEXIS 28187, at*1.

325. Kevin Lee Zimmerman, MURDERPEDIA, http://murderpedia.org/male.Z/zl/ zimmerman-kevin-lee.htm (last visited Nov. 2, 2019); app. B.

326. As we indicated, we have been unable to determine the fate of Larry Jones. See $s u$ pra note 248; infra app. B.

327. Andre Lewis. See email from Richard Ellis, Esq., Lewis's appellate counsel, to authors (Jan. 21, 2019), infra app. B.

328. Federally funded resource centers to assist in death penalty cases were defunded in the 1990 s, though many of these were subsequently resurrected as nonprofit organizations. See Russell Stetler, The Past, Present, and Fulure of the Mitigation Profession: Fulfilling the Constitu- 
not news. But, looking at the way the Fifth Circuit ignored the reality of the trials (and the pre-trial work of counsel) is extraordinarily disconcerting. The combination of the Fifth Circuit's minimization of Strickland standards and the all-too-frequent ineffectiveness of counsel (both in cases in which there were affirmances and cases in which there was reversals) has created a truly toxic world of criminal procedure.

These cases reflect-on the part of trial counsel and the courts-the rankest and vilest sort of sanism and pretextuality. They are textbook examples of how the vividness heuristic and false "ordinary common sense" have utterly contaminated the judicial process in such matters. They also reject every tenet and principle of therapeutic jurisprudence. To say that they do not reflect "an ethic of care" $"$ is to belabor the obvious. To say they encourage attempts "to bring about healing and wellness" $" 330$ is absurd. To say they "value psychological health" is frivolous. As one of the authors (MLP) wrote over twenty years ago, our system of death penalty adjudication-from this TJ perspective-"fails miserably."

The song from which we drew for the title of this Article, Shelter from the Storm, again, reflects a "mythic image of torment." ${ }^{332}$ But, unlike the song, there is nothing "mythic" about this "world of steel-eyed death" that has confronted every defendant in every case which we write about. Convictions are affirmed in cases that should have met the old "farce and mockery" test ${ }^{333}$ that was abandoned in Strickland, decisions that are an embarrassment to our system of criminal law and procedure. Our hopes are that changes in the way capital counsel are evaluated in the future in the states that comprise this circuit will be taken more seriously.

We are failing capital defendants with mental disabilities until we can hold counsel to a higher standard of performance. Ultimately, short of simply abolishing capital punishment, we must ensure that defendants who clearly do not represent "the worst of the worst" (but whose lawyers often are) do not receive the ultimate sanction.

iconal Requirement of Individualized Sentencing in Capilal Cases, 46 HOFSTRA L. REV. 1161, 117678 (2018).

329. Perlin, Mind Made Up, supra note 297, at 94.

330. $I d$.

331. Perlin, Execulioner's Face, supra note 3, at 235.

332. Perlin \& Dlugacz, supra note 13, at 677 (quoting GILL \& OdEGARD, supra note 13, at

163).

333. See supra note 57 (quoting United States v. Wight, 176 F.2d 376, 379 (2d Cir. 1949), cert. denied, 338 U.S. 950 (1950)). 
APPENDIX A

1. STRICKLAND CASES AFFIRMED BY THE FIFTH CIRCUIT:

\begin{tabular}{|c|c|c|}
\hline Defendant name: & $\begin{array}{c}\text { Title: } \\
\end{array}$ & $\begin{array}{l}\text { Case citation: } \\
\end{array}$ \\
\hline Adanandus, Dwight & $\begin{array}{l}\text { Dwight Adanandus v. } \\
\text { Johnson }\end{array}$ & $\begin{array}{l}1997 \text { U.S. App. LEXIS } 43223 \\
\text { (5th Cir. 1997) }\end{array}$ \\
\hline Alexander, Gut & $\begin{array}{l}\text { Gut Alexander v. } \\
\text { Quarterman }\end{array}$ & $\begin{array}{l}198 \text { Fed. Appx. } 354 \text { (5th Cir. } \\
2006 \text { ) }\end{array}$ \\
\hline Alan, Guy & Guy Alan v. Stephens & $\begin{array}{l}619 \text { Fed Appx. } 280 \text { (5th Cir. } \\
2015 \text { ) }\end{array}$ \\
\hline Amos, Bernard & Bernard Amos v. Scott & 61 F. 3d 333 (5th Cir. 1995) \\
\hline Anderson, Larry & Larry Anderson v. Collins & 18 F. 3d 1208 (5th Cir. 1994) \\
\hline Andrews, Maurice & $\begin{array}{l}\text { Maurice Andrews v. } \\
\text { Collins }\end{array}$ & 21 F. 3d 612 (5th Cir. 1994) \\
\hline Austin, Perry & Perry Austin v. Davis & 876 F. 3d 757 (5th Cir. 2017) \\
\hline Avila, Rigoberto & $\begin{array}{l}\text { Rigoberto Avila v. } \\
\text { Quarterman }\end{array}$ & 560 F. 3d 299 (5th Cir. 2009) \\
\hline Ayesta, Carlos & Carlos Ayesta v. Stephens & 817 F. 3d 888 (5th Cir. 2016) \\
\hline Baltazar, John & John Baltazar v. Cockrell & $\begin{array}{l}\text { 2002 U.S. App. LEXIS } 28570 \\
\text { (5th Cir. 2002) }\end{array}$ \\
\hline Banks, Delma & Delma Banks v. Cockrell & $\begin{array}{l}2002 \text { U.S. App. LEXIS } 28401 \\
\text { (5th Cir. 2002) }\end{array}$ \\
\hline Barbee, Stephen & Stephen Barbee v. Davis & $\begin{array}{l}660 \text { Fed. Appx. } 293 \text { (5th Cir. } \\
\text { 2016) }\end{array}$ \\
\hline Barnard, Harold & Harold Barnard v. Collins & 958 F. 2d 634 (5th Cir. 1992) \\
\hline Battaglia, John & John Battaglia v. Stephens & $\begin{array}{l}\text { 621 Fed. Appx. } 781 \text { (5th } \\
\text { Cir.2015) }\end{array}$ \\
\hline Beets, Betty & Betty Beets v. Collins & $\begin{array}{l}986 \text { F. 2d } 1478 \text { (5th Cir. } \\
1993 \text { ) }\end{array}$ \\
\hline Bell, Frederick & Frederick Bell v. Epps & $\begin{array}{l}347 \text { Fed. Appx. } 735 \text { th Cir. } \\
(2009)\end{array}$ \\
\hline Bell, Walter & Walter Bell v. Lynaugh & $\begin{array}{l}828 \text { F. 2d } 1085 \text { (5th Cir. } \\
1987 \text { ) }\end{array}$ \\
\hline Belyeu, Clifton & Clifton Belyeu v. Scott & 67. F. 3d 535 (5th Cir. 1995) \\
\hline Bernard, Brandon & U.S. v. Brandon Bernard & 762 F 3d 467 (5th Cir. 2014) \\
\hline Bishop, Dale & Dale Bishop v. Epps & $\begin{array}{l}265 \text { Fed. Appx. } 285 \text { (5th Cir. } \\
2008 \text { ) }\end{array}$ \\
\hline Black, Robert & Robert Black v. Collins & 962 F. 2d 394 (5th Cir. 1992) \\
\hline Blanton, Reginald & $\begin{array}{l}\text { Reginald Blanton } \mathrm{v} . \\
\text { Quarterman }\end{array}$ & 543 F. 3d 230 (5th Cir. 2008) \\
\hline Boyd, Charles & Charles Boyd v. Johnson & 167 F. 3d 907 (5th Cir. 1999) \\
\hline Boyle, Herbert & Herbert Boyle v. Johnson & 93 F. 3d 180 (5th Cir. 1996) \\
\hline Braziel, Alvin & Alvin Braziel v. Stephens & $\begin{array}{l}631 \text { Fed. Appx. } 225 \text { (5th Cir. } \\
\text { 2015) }\end{array}$ \\
\hline Brawner, Jan & Jan Brawner v. Epps & $\begin{array}{l}439 \text { Fed. Appx. } 396 \text { (5th Cir. } \\
\text { 2011) }\end{array}$ \\
\hline Brown, Arthur & Arthur Brown v. Thaler & 684 F. 3d 482 (5th Cir. 2012) \\
\hline Brown, John & John Brown v. Cain & 104 F. 3d 744 (5th Cir. 1997) \\
\hline
\end{tabular}


WINTER 2019]

\begin{tabular}{|c|c|c|}
\hline Busby, Davis & Davis Busby v. Davis & $\begin{array}{l}677 \text { Fed. Appx. } 884 \text { (5th Cir. } \\
2017 \text { ) }\end{array}$ \\
\hline Byrne, Edward & Edward Bryne v. Butler & 845 F. 2d 501 (5th Cir. 1988) \\
\hline Cannon, Joseph & $\begin{array}{l}\text { Joseph Cannon v. } \\
\text { Johnson }\end{array}$ & 134 F. 3d 683 (5th Cir. 1998) \\
\hline Cantu, Ivan & Ivan Cantu v. Thaler & 632 F. 3d 157 (5th Cir. 2011) \\
\hline Cantu, Ruben & Ruben Cantu v. Collins & $\begin{array}{l}967 \text { F. 2d } 1006 \text { (5th Cir. } \\
1992 \text { ) }\end{array}$ \\
\hline Carter, Robert & Robert Carter v. Johnson & 131 F. 3d 452 (5th Cir. 1997) \\
\hline Castillo, Juan & Juan Castillo v. Stephens & $\begin{array}{l}\text { 640 Fed. Appx } 283 \text { (5th Cir. } \\
2016 \text { ) }\end{array}$ \\
\hline Celestine, Willie & $\begin{array}{l}\text { Willie, Celestine v. } \\
\text { Blackburn }\end{array}$ & 750 F. 2d 353 (5th Cir. 1984) \\
\hline Charles, Derrick & $\begin{array}{l}\text { Derrick Charles v. } \\
\text { Stephens }\end{array}$ & 736 F. 3d 380 (5th Cir. 2013) \\
\hline Chase, Ricky & Rickey Chase v. Epps & $\begin{array}{l}83 \text { Fed. Appx. } 673 \text { (5th Cir. } \\
2003 \text { ) }\end{array}$ \\
\hline Clark, David & David Clark v. Collins & $756 \mathrm{~F} .2 \mathrm{~d} 68(1992)$ \\
\hline Clark, Herman & Herman Clark v. Collins & 19 F. 3d 959 (1994) \\
\hline Coble, Billie & Billie Coble v. Davis & 682 Fed. Appx 261 (2017) \\
\hline Cockrell, Timothy & $\begin{array}{l}\text { Timothy Cockrell v. } \\
\text { Dretke }\end{array}$ & $\begin{array}{l}88 \text { Fed. Appx } 34 \text { (5th Cir. } \\
\text { 2004) }\end{array}$ \\
\hline Cockrum, John & John Cockrum v. Johnson & 119 F. 3d 297 (5th Cir. 1997) \\
\hline Coleman, Lisa & Lisa Coleman v. Thaler & 716 F. 3d 895 (5th Cir. 2013) \\
\hline Conner, Ronnie & Ronnie Conner v. Epps & $\begin{array}{l}2002 \text { U.S. App LEXIS } 29673 \\
\text { (5th Cir. 2002) }\end{array}$ \\
\hline Crane, Alvin & Alvin Crane v. Johnson & 178 F. 3d 309 (5th Cir. 1999) \\
\hline Crawford, Charles & Charles Crawford v. Epps & $\begin{array}{l}353 \text { Fed. Appx. } 977 \text { (5th Cir. } \\
2009 \text { ) }\end{array}$ \\
\hline Crutsinger, Billy & $\begin{array}{l}\text { Billy Crutsinger v. } \\
\text { Stephens }\end{array}$ & $\begin{array}{l}576 \text { Fed. App. } 422 \text { (5th Cir. } \\
2014 \text { ) }\end{array}$ \\
\hline Devoe, Paul & Paul Devoe v. Davis & $\begin{array}{l}2018 \text { U.S. App LEXIS } 514 \\
\text { (5th Cir. 2018) }\end{array}$ \\
\hline Dowthitt, Dennis & $\begin{array}{l}\text { Dennis Dowthitt v. } \\
\text { Johnson }\end{array}$ & 230 F. 3d 733 (5th Cir. 2000) \\
\hline Drew, Robert & Robert Drew v. Collins & 964 F. 2d 411 (5th Cir. 1992) \\
\hline Druery, Marcus & Marcus Druery v. Thaler & 647 F. 3d 535 (5th Cir. 2011) \\
\hline Enriguez, Juan & $\begin{array}{l}\text { Juan Enrigues v. } \\
\text { Procunier }\end{array}$ & 752 F. 2d 111 (5th Cir. 1984) \\
\hline Escamilla, Licho & $\begin{array}{l}\text { Licho Escamilla v. } \\
\text { Stephens }\end{array}$ & $\begin{array}{l}602 \text { Fed. Appx. } 939 \text { (5th Cir. } \\
2015)\end{array}$ \\
\hline Esparza, Guadalupe & $\begin{array}{l}\text { Guadalupe Esparza v. } \\
\text { Thaler }\end{array}$ & $\begin{array}{l}\text { 408 Fed. Appx. } 787 \text { (5th Cir. } \\
2010 \text { ) }\end{array}$ \\
\hline Evans, Connie & Connie Evans v. Cabana & $\begin{array}{l}821 \text { F. 2d } 1065 \text { (5th Cir. } \\
1987 \text { ) }\end{array}$ \\
\hline Faulderv, Joseph & $\begin{array}{l}\text { Joseph Faulderv v. } \\
\text { Johnson }\end{array}$ & 81 F. 3d 515 (5th Cir. 1996) \\
\hline Felde, Wayne & Wayne Felde v. Butler & 817 F. 2d 281 (5th Cir. 1987) \\
\hline Feldman, Douglas & $\begin{array}{l}\text { Douglas Feldman v. } \\
\text { Thaler }\end{array}$ & 695 F. 3d 372 (5th Cir. 2012) \\
\hline Flores, Andrew & Andrew Flores v. Dretke & 82 Fed. Appx. 92 (5th Cir. \\
\hline
\end{tabular}




\begin{tabular}{|c|c|c|}
\hline & & 2003) \\
\hline Flores, Charles & Charles Flores v. Stephens & 794 F. 3d 494 (5th Cir. 2015) \\
\hline Foster, Ron & Ron Foster v. Johnson & 293 F. 3d 766 (5th Cir. 2002) \\
\hline Freeman, James & $\begin{array}{l}\text { James Freeman v. } \\
\text { Stephens }\end{array}$ & $\begin{array}{l}614 \text { Fed. Appx. } 180 \text { (5th Cir. } \\
2015 \text { ) }\end{array}$ \\
\hline Gallamore, Samuel & $\begin{array}{l}\text { Samuel Gallamore v. } \\
\text { Cockrell }\end{array}$ & $\begin{array}{l}\text { 2001 U.S. App. LEXIS } 31510 \\
\text { (5th Cir. 2001) }\end{array}$ \\
\hline Garza, Manuel & Manuel Garza v. Stephens & 738 F. 3d 669 (5th Cir. 2013) \\
\hline Garza, Robert & Robert Garza v. Thaler & $\begin{array}{l}487 \text { Fed. Appx. } 907 \text { (5th Cir. } \\
2012 \text { ) }\end{array}$ \\
\hline Gates, Bill & Bill Gates v. Davis & $\begin{array}{l}660 \text { Fed. Appx. } 270 \text { (5th Cir. } \\
2016 \text { ) }\end{array}$ \\
\hline Gentry, Kenneth & $\begin{array}{l}\text { Kenneth Gentry v. } \\
\text { Johnson }\end{array}$ & $\begin{array}{l}\text { 1996 U.S. App. LEXIS } 43513 \\
\text { (5th Cir. 1996) }\end{array}$ \\
\hline Gonzales, Ramiro & Ramiro Gonzales & $\begin{array}{l}606 \text { Fed. Appx. } 767 \text { (5th Cir. } \\
2015 \text { ) }\end{array}$ \\
\hline Green, Dominique & $\begin{array}{l}\text { Dominique Green v. } \\
\text { Dretke }\end{array}$ & $\begin{array}{l}82 \text { Fed. Appx. } 333 \text { (5th Cir. } \\
\text { 2003) }\end{array}$ \\
\hline Green, Edward & Edward Green v. Cockrell & $\begin{array}{l}2003 \text { U.S. App. LEXIS } 28425 \\
\text { (5th Cir. 2003) }\end{array}$ \\
\hline Green, Ricky & Ricky Green v. Johnson & $\begin{array}{l}116 \text { F. 3d } 1115 \text { (5th Cir. } \\
1997)\end{array}$ \\
\hline Gray, Rodney & Rodney Gray v. Epps & 616 F. 3d 436 (5th Cir. 2010) \\
\hline Guevara, Gilmar & $\begin{array}{l}\text { Gilmar Guevara v. } \\
\text { Stephens }\end{array}$ & $\begin{array}{l}577 \text { Fed. Appx. } 364 \text { (5th Cir. } \\
\text { 2014) }\end{array}$ \\
\hline Hammond, Karl & Karl Hammond v. Scott & $\begin{array}{l}\text { 1994 U.S. App. LEXIS } 43045 \\
\text { (1994) }\end{array}$ \\
\hline Hankins, Terry & $\begin{array}{l}\text { Terry Hankins v. } \\
\text { Quarterman }\end{array}$ & $\begin{array}{l}288 \text { Fed. Appx. } 952 \text { (5th Cir. } \\
2008 \text { ) }\end{array}$ \\
\hline Harris, David & David Harris v. Cockrell & 313 F. 3d 238 (5th Cir. 2002) \\
\hline Hernandez, Rogelio & $\begin{array}{l}\text { Rogelio Hernandez v. } \\
\text { Johnson }\end{array}$ & $\begin{array}{l}1997 \text { U.S. App. LEXIS } 12686 \\
\text { (5th Cir. 1997) }\end{array}$ \\
\hline Hoffman, Jessie & Jessie Hoffman v. Cain & 752 F. 3d 430 (5th Cir. 2014) \\
\hline Hood, Charles & Charles Hood v. Dretke & $\begin{array}{l}93 \text { Fed. Appx. } 665 \text { (5th Cir. } \\
\text { 2004) }\end{array}$ \\
\hline Hudson, Robert & $\begin{array}{l}\text { Robert Hudson v. } \\
\text { Quarterman }\end{array}$ & $\begin{array}{l}273 \text { Fed. Appx. } 331 \text { (5th Cir. } \\
2008 \text { ) }\end{array}$ \\
\hline Jackson, Henry & Henry Jackson v. Epps & $\begin{array}{l}\text { 447 Fed. Appx. } 535 \text { (5th Cir. } \\
2011 \text { ) }\end{array}$ \\
\hline Jennings, Robert & $\begin{array}{l}\text { Robert Jennings v. } \\
\text { Stephens }\end{array}$ & $\begin{array}{l}537 \text { Fed. Appx. } 326 \text { (5th Cir. } \\
\text { 2013) }\end{array}$ \\
\hline Johnson, Edward & $\begin{array}{l}\text { Edward Johnson v. } \\
\text { Cabana }\end{array}$ & 818 F. 2d 333 (5th Cir. 1987) \\
\hline Johnson, Michael & $\begin{array}{l}\text { Michael Johnson v. } \\
\text { Cockrell }\end{array}$ & 306 F. 3d 249 (5th Cir. 2002) \\
\hline Jones, Anzel & Anzel Jones v. Cockrell & $\begin{array}{l}74 \text { Fed. Appx. } 317 \text { (5th Cir. } \\
\text { 2003) }\end{array}$ \\
\hline Jones, Larry & Larry Jones v. Thigpen & $\begin{array}{l}788 \text { F. 2d } 1101 \text { (5th Cir. } \\
1986 \text { ) }\end{array}$ \\
\hline Jordan, Richard & Richard Jordan v. Epps & 756 F. 3d 395 (5th Cir. 2014) \\
\hline King, John & John King v. Davis & 703 Fed. Appx. 320 (5th Cir. \\
\hline
\end{tabular}




\begin{tabular}{|c|c|c|}
\hline & & 2017) \\
\hline King, Mack & Mack King v. Puckett & 1 F. 3d 280 (5th Cir. 1993) \\
\hline Kitchens, William & $\begin{array}{l}\text { William Kitchens v. } \\
\text { Johnson }\end{array}$ & 190 F. 3d 698 (5th Cir. 1999) \\
\hline Knight, Patrick & $\begin{array}{l}\text { Patrick Knight v. } \\
\text { Quarterman }\end{array}$ & $\begin{array}{l}186 \text { Fed. Appx. } 518 \text { (5th Cir. } \\
2006 \text { ) }\end{array}$ \\
\hline Koon, Walter & Walter Koon v. Cain & $\begin{array}{l}\text { 277 Fed. Appx. } 381 \text { (5th Cir. } \\
2008 \text { ) }\end{array}$ \\
\hline Kunkle, Troy & Troy Kunkle v. Dretke & 352 F. 3d 980 (5th Cir. 2003) \\
\hline Kyles, Curtis & Curtis Kyles v. Whitley & 5 F. 3d 806 (5th Cir. 1993) \\
\hline Ladd, Robert & Robert Ladd v. Cockrell & 311 F. 3d 349 (5th Cir. 2002) \\
\hline LaGrone, Edward & $\begin{array}{l}\text { Edward LaGrone v. } \\
\text { Cockrell }\end{array}$ & $\begin{array}{l}2003 \text { U.S. App. LEXIS } 18150 \\
\text { (5th Cir. 2003) }\end{array}$ \\
\hline Lewis, Andre & Andre Lewis v. Johnson & $\begin{array}{l}2000 \text { U.S. App. LEXIS } 38771 \\
\text { (5th Cir. 2000) }\end{array}$ \\
\hline Lincecum, Kavin & Kavin Lincecum v. Collins & $\begin{array}{l}\text { 958 F. 2d } 1271 \text { (5th Cir. } \\
1992 \text { ) }\end{array}$ \\
\hline Little, William & William Little v. Johnson & 162 F. 3d 855 (5th Cir. 1998) \\
\hline Lockett, Carl & Carl Lockett v. Anderson & 230 F. 3d 695 (5th Cir. 2000) \\
\hline Lowenfield, Leslie & $\begin{array}{l}\text { Leslie Lowenfield v. } \\
\text { Phelps }\end{array}$ & 817 F. 2d 285 (5th Cir. 1987) \\
\hline Loyd, Alvin & Alvin Loyd v. Whitley & 977 F. 2d 149 (5th Cir. 1992) \\
\hline Mann, Fletcher & Fletcher Mann v. Scott & 41 F. 3d 968 (5th Cir. 1994) \\
\hline Martinez, David & $\begin{array}{l}\text { David Martinez v. } \\
\text { Quarterman }\end{array}$ & $\begin{array}{l}270 \text { Fed. Appx. } 277 \text { (5th Cir. } \\
2008 \text { ) }\end{array}$ \\
\hline Martinez, Raymond & $\begin{array}{l}\text { Raymond Martinez v. } \\
\text { Davis }\end{array}$ & $\begin{array}{l}\text { 653 Fed. Appx. } 308 \text { (5th Cir. } \\
2016 \text { ) }\end{array}$ \\
\hline Martinez, Virgil & $\begin{array}{l}\text { Virgil Martinez v. } \\
\text { Quarterman }\end{array}$ & 481 F. 3d 249 (5th Cir. 2007) \\
\hline Masterson, Richard & $\begin{array}{l}\text { Richard Masterson v. } \\
\text { Stephens }\end{array}$ & $\begin{array}{l}596 \text { Fed. Appx. } 282 \text { (5th Cir. } \\
2015 \text { ) }\end{array}$ \\
\hline Mathis, Milton & Milton Mathis v. Dretke & $\begin{array}{l}124 \text { Fed. Appx. } 865 \text { (5th Cir. } \\
2005 \text { ) }\end{array}$ \\
\hline Mattheson, Howard & $\begin{array}{l}\text { Howard Mattheson v. } \\
\text { King }\end{array}$ & $\begin{array}{l}751 \mathrm{~F} .2 \mathrm{~d} 1432 \text { (5th Cir. } \\
1985)\end{array}$ \\
\hline Mays, Randall & Randall Mays v. Stephens & 757 F. 3d 211 (5th Cir. 2014) \\
\hline McBride, Michael & $\begin{array}{l}\text { Michael McBride v. } \\
\text { Johnson }\end{array}$ & $\begin{array}{l}\text { 1997 U.S. App. LEXIS } 42198 \\
\text { (5th Cir. 1997) }\end{array}$ \\
\hline McCoy, Stephen & $\begin{array}{l}\text { Stephen McCoy v. } \\
\text { Lynaugh }\end{array}$ & 874 F. 2d 954 (5th Cir. 1989) \\
\hline Miniel, Peter & Peter Miniel v. Cockrell & 339 F. 3d 331 (5th Cir. 2003) \\
\hline Mitchell, William & William Mitchell v. Epps & 641 F. 3d 134 (5th Cir. 2011) \\
\hline Moody, John & John Moody v. Johnson & 139 F. 3d 477 (5th Cir. 1998) \\
\hline Moore, Bobby & Bobby Moore v. Johnson & 194 F. 3d 586 (5th Cir. 1999) \\
\hline Moore, Jonathan & Jonathan Moore v. Dretke & $\begin{array}{l}182 \text { Fed. Appx. } 329 \text { (5th Cir. } \\
2006 \text { ) }\end{array}$ \\
\hline Mosley, Kenneth & $\begin{array}{l}\text { Kenneth Mosley v. } \\
\text { Quarterman }\end{array}$ & $\begin{array}{l}306 \text { Fed. Appx. } 40 \text { (5th Cir. } \\
2008 \text { ) }\end{array}$ \\
\hline Motley, Jeffrey & Jeffrey Motley v. Collins & 18 F. 3d 1223 (5th Cir. 1994) \\
\hline Neal, Howard & Howard Neal v. Puckett & 286 F. 3d 230 (5th Cir. 2002) \\
\hline Newbury, Donald & Donald Newbury v. & 756 F. 3d 850 (5th Cir. 2014) \\
\hline
\end{tabular}




\begin{tabular}{|c|c|c|}
\hline & Stephens & \\
\hline Nixon, John & John Nixon v. Epps & 405 F. 3d 318 (5th Cir. 2005) \\
\hline Nobles, Jonathan & $\begin{array}{l}\text { Jonathan Nobles v. } \\
\text { Johnson }\end{array}$ & 127 F. 3d 409 (5th Cir. 1997) \\
\hline Norman, LeJames & $\begin{array}{l}\text { LeJames Norman v. } \\
\text { Stephens }\end{array}$ & 817 F. 3d 226 (5th Cir. 2016) \\
\hline Nuncio, Paul & Paul Nuncio v. Johnson & $\begin{array}{l}2000 \text { U.S. App. LEXIS } 41233 \\
\text { (5th Cir. } 2000)\end{array}$ \\
\hline O'Brien, Derrick & Derrick O'Brien v. Dretke & $\begin{array}{l}156 \text { Fed. Appx. } 724 \text { (5th Cir. } \\
2005 \text { ) }\end{array}$ \\
\hline Ogan, Craig & Craig Ogan v. Cockrell & 297 F. 3d 349 (5th Cir. 2002) \\
\hline Paredes, Miguel & In re Miguel Paredes & $\begin{array}{l}587 \text { Fed. Appx. } 805 \text { (5th Cir. } \\
2014 \text { ) }\end{array}$ \\
\hline Patterson, Kelsey & $\begin{array}{l}\text { Kelsey Patterson v. } \\
\text { Cockrell }\end{array}$ & $\begin{array}{l}2033 \text { U.S. App. LEXIS } 28033 \\
\text { (5th Cir. 2003) }\end{array}$ \\
\hline Perkins, Reginald & $\begin{array}{l}\text { Reginald Perkins v. } \\
\text { Quarterman }\end{array}$ & $\begin{array}{l}\text { 254 Fed. Appx. } 366 \text { (5th Cir. } \\
\text { 2007) }\end{array}$ \\
\hline Perry, Michael & $\begin{array}{l}\text { Michael Perry v. } \\
\text { Quarterman }\end{array}$ & $\begin{array}{l}\text { 314 Fed. Appx. } 663 \text { (5th Cir. } \\
\text { 2009) }\end{array}$ \\
\hline Pierce, Anthony & Anthony Pierce v. Thaler & $\begin{array}{l}355 \text { Fed. Appx. } 784 \text { (5th Cir. } \\
2009 \text { ) }\end{array}$ \\
\hline Prejean, Dalton & Dalton Prejean v. Smith & $\begin{array}{l}889 \text { F. 2d } 1391 \text { (5th Cir. } \\
1989 \text { ) }\end{array}$ \\
\hline Raby, Charles & Charles Raby v. Dretke & $\begin{array}{l}78 \text { Fed. Appx. } 324 \text { (5th Cir. } \\
2003 \text { ) }\end{array}$ \\
\hline Rayford, William & $\begin{array}{l}\text { William Rayford v. } \\
\text { Stephens }\end{array}$ & $\begin{array}{l}622 \text { Fed. Appx. } 315 \text { (5th Cir. } \\
\text { 2015) }\end{array}$ \\
\hline Rector, Charles & Charles Rector v. Johnson & 120 F. 3d 551 (5th Cir. 1997) \\
\hline Riles, Raymond & $\begin{array}{l}\text { Raymond Riles v. } \\
\text { McCotter }\end{array}$ & 799 F. 2d 947 (5th Cir. 1986) \\
\hline Riley, Michael & Michael Riley v. Dretke & 362 F. 3d 302 (5th Cir. 2004) \\
\hline Robertson, Brian & $\begin{array}{l}\text { Brian Robertson v. } \\
\text { Johnson }\end{array}$ & $\begin{array}{l}2000 \text { U.S. App. LEXIS } 40417 \\
\text { (5th Cir. 2000) }\end{array}$ \\
\hline Roberts, Douglas & Douglas Roberts v. Dretke & 381 F. 3d 491 (5th Cir. 2004) \\
\hline Robison, Larry & Larry Robison v. Johnson & 151 F. 3d 256 (5th Cir. 1998) \\
\hline Rockwell, Kwame & Kwame Rockwell v. Davis & 853 F. 3d 758 (5th Cir. 2017) \\
\hline Rodriguez, Rosendo & $\begin{array}{l}\text { Rosendo Rodriguez v. } \\
\text { Davis }\end{array}$ & $\begin{array}{l}693 \text { Fed. Appx. } 276 \text { (5th Cir. } \\
2017 \text { ) }\end{array}$ \\
\hline Romero, Jesus & Jesus Romero v. Lynaugh & 884 F. 2d 871 (5th Cir. 1989) \\
\hline Saldaño, Victor & Victor Saldaño v. Davis & $\begin{array}{l}701 \text { Fed. Appx. } 302 \text { (5th Cir. } \\
\text { 2017) }\end{array}$ \\
\hline Santellan, Jose & Jose Santellan v. Cockrell & 271 F. 3d 190 (5th Cir. 190) \\
\hline Sattiewhite, Vernon & $\begin{array}{l}\text { Vernon Sattiewhite v. } \\
\text { Scott }\end{array}$ & $\begin{array}{l}1995 \text { U.S. App. LEXIS } 41815 \\
\text { (5th Cir. 1995) }\end{array}$ \\
\hline Sawyer, Robert & Robert Sawyer v. Butler & 848 F. 2d 582 (5th Cir. 1988) \\
\hline Segundo, Juan & Juan Segundo v. Davis & 831 F. 3d 345 (5th Cir. 2016) \\
\hline Sells, Tommy & Tommy Sells v. Stephens & $\begin{array}{l}536 \text { Fed. Appx. } 483 \text { (5th Cir. } \\
\text { 2013) }\end{array}$ \\
\hline Selvage, John & John Selvage v. Lynaugh & 842 F. 2d 89 (5th Cir. 1988) \\
\hline $\begin{array}{l}\text { Sepulvado, } \\
\text { Christopher }\end{array}$ & $\begin{array}{l}\text { Christopher Sepulvado v. } \\
\text { Cain }\end{array}$ & $\begin{array}{l}2003 \text { U.S. App. LEXIS } 28732 \\
\text { (5th Cir. 2003) }\end{array}$ \\
\hline
\end{tabular}




\begin{tabular}{|c|c|c|}
\hline Shore, Anthony & Anthony Shore v. Davis & 845 F. 3d 627 (5th Cir. 2017) \\
\hline Sigala, Michael & $\begin{array}{l}\text { Michael Sigala v. } \\
\text { Quarterman }\end{array}$ & $\begin{array}{l}338 \text { Fed. Appx. } 388 \text { (5th Cir. } \\
2009 \text { ) }\end{array}$ \\
\hline Simmons, Gary & Gary Simmons v. Epps & $\begin{array}{l}381 \text { Fed. Appx. } 339 \text { (5th Gir. } \\
2010 \text { ) }\end{array}$ \\
\hline Slater, Paul & Paul Slater v. Davis & $\begin{array}{l}2018 \text { U.S. App. LEXIS } 901 \\
\text { (5th Cir. 2018) }\end{array}$ \\
\hline Smith, Charles & $\begin{array}{l}\text { Charles Smith v. } \\
\text { Quarterman }\end{array}$ & 471 F. 3d 565 (5th Cir. 2006) \\
\hline Smith, Robert & Robert Smith v. Crockwell & 311 F. 3d 661 (5th Cir. 2002) \\
\hline Smith, Roy & Roy Smith v. Quarterman & 515 F. 3d 392 (5th Cir. 2008) \\
\hline Smith, Willie & Willie Smith v. Black & 904 F. 2d 950 (5th Cir. 1990) \\
\hline Sosa, Pedro & Pedro Sosa v. Dretke & $\begin{array}{l}133 \text { Fed. Appx. } 114 \text { (5th Cir. } \\
2005)\end{array}$ \\
\hline Stoker, David & David Stoker v. Scott & $\begin{array}{l}\text { 1996 U.S. App. LEXIS } 42604 \\
\text { (5th Cir. 1996) }\end{array}$ \\
\hline Storey, Paul & Paul Storey v. Stephens & $\begin{array}{l}606 \text { Fed Appx. } 192 \text { (5th Cir. } \\
\text { 2015) }\end{array}$ \\
\hline Tamayo, Edgar & Edgar Tamayo v. Thaler & $\begin{array}{l}\text { 2011 U.S. App. LEXIS } 26665 \\
\text { (5th Cir. 2011) }\end{array}$ \\
\hline Thompson, John & John Thompson v. Cain & 161 F. 3d 802 (5th Cir. 1998) \\
\hline Thompson, Robert & $\begin{array}{l}\text { Robert Thompson v. } \\
\text { Quarterman }\end{array}$ & $\begin{array}{l}\text { 292 Fed. Appx. } 277 \text { (5th Cir. } \\
2008 \text { ) }\end{array}$ \\
\hline Titsworth, Timothy & $\begin{array}{l}\text { Timothy Titsworth v. } \\
\text { Dretke }\end{array}$ & 401 F. 3d 301 (5th Cir. 2005) \\
\hline Trevino, Carlos & Carlos Trevino v. Davis & 829 F. 3d 328 (5th Cir. 2016) \\
\hline Trottie, Willie & Willie Trottie v. Stephens & 720 F. 3d 231 (5th Cir. 2013) \\
\hline Tucker, Karla & Karla Tucker v. Johnson & $\begin{array}{l}1997 \text { U.S. App. LEXIS } 16312 \\
\text { (5th Cir. 1997) }\end{array}$ \\
\hline Tucker, Jeffrey & Jeffrey Tucker v. Johnson & 242 F. 3d 617 (5th Cir. 2001) \\
\hline Turner, Edwin & Edwin Turnerv. Epps & $\begin{array}{l}\text { 412 Fed. Appx. } 696 \text { (5th Cir. } \\
\text { 2011) }\end{array}$ \\
\hline $\begin{array}{l}\text { Van Alstyne, } \\
\text { Gregory } \\
\end{array}$ & $\begin{array}{l}\text { Gregory Van Alstyne v. } \\
\text { Cockrell }\end{array}$ & $\begin{array}{l}2002 \text { U.S. App. LEXIS } 29069 \\
\text { (5th Cir.2002) }\end{array}$ \\
\hline Valle, Yosvannis & $\begin{array}{l}\text { Yosvannis Valle v. } \\
\text { Quarterman }\end{array}$ & $\begin{array}{l}2008 \text { U.S. App. LEXIS } 22165 \\
\text { (5th Cir. 2008) }\end{array}$ \\
\hline Vasquez, Richard & Richard Vasquez v. Thaler & $\begin{array}{l}389 \text { Fed. Appx. } 419 \text { (5th Cir. } \\
2010)\end{array}$ \\
\hline Villegas, Jose & $\begin{array}{l}\text { Jose Villegas v. } \\
\text { Quarterman }\end{array}$ & $\begin{array}{l}274 \text { Fed. Appx. } 378 \text { (5th Cir. } \\
2008 \text { ) }\end{array}$ \\
\hline Walbey, Gaylon & $\begin{array}{l}\text { Gaylon Walbey v. } \\
\text { Quarterman }\end{array}$ & $\begin{array}{l}309 \text { Fed. Appx. } 795 \text { (5th Gir. } \\
\text { 2009) }\end{array}$ \\
\hline Ward, Adam & Adam Ward v. Stephens & 777 F. 3d 250 (5th Cir. 2015) \\
\hline Washington, Terry & $\begin{array}{l}\text { Terry Washington v. } \\
\text { Johnson }\end{array}$ & 90 F. 3d 945 (5th Cir. 1996) \\
\hline Wesbrook, Coy & Coy Wesbrook v. Thaler & 585 F. 3d 245 (5th Cir. 2009) \\
\hline West, Robert & Robert West v. Johnson & 92 F. 3d 1385 (5th Cir. 1996) \\
\hline Wheat, John & John Wheat v. Johnson & 238 F. 3d 357 (5th Cir. 2001) \\
\hline Whitaker, George & $\begin{array}{l}\text { George Whitaker v. } \\
\text { Quarterman }\end{array}$ & $\begin{array}{l}200 \text { Fed. Appx. 351 (5th Cir. } \\
2006 \text { ) }\end{array}$ \\
\hline
\end{tabular}




\begin{tabular}{|c|c|c|}
\hline White, Robert & Robert White v. Johnson & 153 F. 3d 197 (5th Cir. 1998) \\
\hline Wiley, William & William Wiley v. Puckett & 969 F. 2d 86 (5th Cir. 1992) \\
\hline Wilkerson, Richard & $\begin{array}{l}\text { Richard Wilkerson v. } \\
\text { Collins }\end{array}$ & $\begin{array}{l}950 \text { F. 2d } 1054 \text { (5th Cir. } \\
1992)\end{array}$ \\
\hline $\begin{array}{l}\text { Wilkins, } \\
\text { Christopher }\end{array}$ & $\begin{array}{l}\text { Christopher Wilkins v. } \\
\text { Stephens }\end{array}$ & $\begin{array}{l}560 \text { Fed. Appx. } 299 \text { (5th Cir. } \\
\text { 2014) }\end{array}$ \\
\hline Williams, Clifton & $\begin{array}{l}\text { Clifton Williams v. } \\
\text { Stephens }\end{array}$ & 761 F. 3D 561 (5th Cir. 2014) \\
\hline Williams, Dobie & Dobie Williams v. Cain & 125 F. 3d 269 (5th Cir. 1997) \\
\hline Williams, Walter & Walter Williams v. Collins & 16 F. 3d 626 (5th Cir. 1994) \\
\hline Willie, Robert & Robert Willie v. Maggio & $\begin{array}{l}737 \text { F. 2d } 1372 \text { (5th Gir. } \\
1984 \text { ) }\end{array}$ \\
\hline Wilson, David & David Wilson v. Butler & 813 F. 2d 664 (5th Cir. 1987) \\
\hline Woodard, Robert & Robert Woodard v. Thaler & $\begin{array}{l}\text { 414 Fed. Appx. } 675 \text { (5th Cir. } \\
2011 \text { ) }\end{array}$ \\
\hline Woods, Billy & Billy Woods v. Johnson & 75 F. 3d 1017 (5th Cir. 1996) \\
\hline Woods, Steven & Steven Woods v. Thaler & $\begin{array}{l}399 \text { Fed. Appx. } 884 \text { (5th Cir. } \\
2010 \text { ) }\end{array}$ \\
\hline Yowell, Michael & Michael Yowell v. Thaler & $\begin{array}{l}442 \text { Fed. Appx. } 100 \text { (5th Cir. } \\
2011 \text { ) }\end{array}$ \\
\hline Zimmerman, Kevin & $\begin{array}{l}\text { Kevin Zimmerman v. } \\
\text { Cockrell }\end{array}$ & $\begin{array}{l}2002 \text { U.S. App. LEXIS } 28187 \\
\text { (5th Cir. 2002) }\end{array}$ \\
\hline
\end{tabular}

\section{STRICKLAND CASES REVERSED BY THE FIFTH CIRCUIT $(\mathrm{N}=13 / 198=6.5 \%)$}

\begin{tabular}{|c|c|c|}
\hline Busby, Edward & Edward Busby v. Davis & $\begin{array}{l}677 \text { Fed. Appx. } 884 \text { (5th Cir. } \\
2017 \text { ) }\end{array}$ \\
\hline Jones, Larry & Larry Jones v. Thigpen & 788 F. 2d 1101 (5th Cir. 1986) \\
\hline Koon, Walter & Walter Koon v. Cain & $\begin{array}{l}277 \text { Fed. Appx. } 381 \text { (5th Cir. } \\
2008 \text { ) }\end{array}$ \\
\hline Lewis, Andre & Andre Lewis v. Johnson & $\begin{array}{l}2000 \text { U.S. App. LEXIS } 38771 \\
\text { (5th Cir. } 2000 \text { ) }\end{array}$ \\
\hline Lockett, Carl & Carl Lockett v. Anderson & 230 F. 3d 695 (5th Cir. 2000) \\
\hline Loyd, Alvin & Alvin Loyd v. Whitley & 977 F. 2d 149 (5th Cir. 1992) \\
\hline Moore, Bobby & Bobby Moore v. Johnson & 194 F. 3d 586 (5th Cir. 1999) \\
\hline Pierce, Anthony & Anthony Pierce v. Thaler & $\begin{array}{l}355 \text { Fed. Appx. } 784 \text { (5th Cir. } \\
2009 \text { ) }\end{array}$ \\
\hline Saldaño, Victor & Victor Saldaño v. Davis & $\begin{array}{l}701 \text { Fed. Appx. } 302 \text { (5th Cir. } \\
2017 \text { ) }\end{array}$ \\
\hline Trevino, Carlos & Carlos Trevino v. Davis & 829 F. 3d 328 (5th Cir. 2016) \\
\hline Walbey, Gaylon & $\begin{array}{l}\text { Gaylon Walbey v. } \\
\text { Quarterman }\end{array}$ & $\begin{array}{l}309 \text { Fed. Appx. } 795 \text { (5th Cir. } \\
2009 \text { ) }\end{array}$ \\
\hline Wilson, David & David Wilson v. Butler & 813 F. 2d 664 (5th Cir. 1987) \\
\hline Zimmerman, Kevin & $\begin{array}{l}\text { Kevin Zimmerman v. } \\
\text { Cockrell }\end{array}$ & $\begin{array}{l}2002 \text { U.S. App. LEXIS } 28187 \\
\text { (5th Cir. 2002) }\end{array}$ \\
\hline
\end{tabular}




\section{STRICKLAND CASES INVOLVING COMPETENCY ISSUES}

$$
(\mathrm{N}=18 / 198=9.6 \%)
$$

\begin{tabular}{|c|c|c|}
\hline Defendant name: & Title: & $\begin{array}{l}\text { Case Citation: } \\
\end{array}$ \\
\hline Austin, Perry & Perry Austin v. Davis & 876 F. 3d 757 (5th Cir. 2017) \\
\hline Carter, Robert & Robert Carter v. Johnson & 131 F. 3d 452 (5th Cir. 1997) \\
\hline Crawford, Charles & Charles Crawford v. Epps & $\begin{array}{l}353 \text { Fed. Appx. } 977 \text { (5th Cir. } \\
2009 \text { ) }\end{array}$ \\
\hline Enriguez, Juan & $\begin{array}{l}\text { Juan Enrigues v. } \\
\text { Procunier }\end{array}$ & 752 F. 2d 111 (5th Cir. 1984) \\
\hline Felde, Wayne & Wayne Felde v. Butler & 817 F. 2d 281 (5th Cir. 1987) \\
\hline King, John & John King v. Davis & $\begin{array}{l}703 \text { Fed. Appx. } 320 \text { (5th Cir. } \\
2017 \text { ) }\end{array}$ \\
\hline Mays, Randall & Randall Mays v. Stephens & 757 F. 3d 211 (5th Cir. 2014) \\
\hline McBride, Michael & $\begin{array}{l}\text { Michael McBride v. } \\
\text { Johnson }\end{array}$ & $\begin{array}{l}1997 \text { U.S. App. LEXIS } 42198 \\
\text { (5th Cir. 1997) }\end{array}$ \\
\hline McCoy, Stephen & $\begin{array}{l}\text { Stephen McCoyv. } \\
\text { Lynaugh }\end{array}$ & 874 F. 2d 954 (5th Cir. 1989) \\
\hline Moody, John & John Moody v. Johnson & 139 F. 3d 477 (5th Cir. 1998) \\
\hline Moore, Jonathan & $\begin{array}{l}\text { Jonathan Moore v. } \\
\text { Dretke }\end{array}$ & $\begin{array}{l}182 \text { Fed. Appx. } 329 \text { (5th Cir. } \\
2006 \text { ) }\end{array}$ \\
\hline Patterson, Kelsey & $\begin{array}{l}\text { Kelsey Patterson v. } \\
\text { Cockrell } \\
\end{array}$ & $\begin{array}{l}2033 \text { U.S. App. LEXIS } 28033 \\
\text { (5th Cir. 2003) }\end{array}$ \\
\hline Saldaño, Victor & Victor Saldaño v. Davis & $\begin{array}{l}701 \text { Fed. Appx. } 302 \text { (5th Cir. } \\
\text { 2017) }\end{array}$ \\
\hline Sosa, Pedro & Pedro Sosa v. Dretke & $\begin{array}{l}133 \text { Fed. Appx. } 114 \text { (5th Cir. } \\
2005 \text { ) }\end{array}$ \\
\hline Trottie, Willie & Willie Trottie v. Stephens & 720 F. 3d 231 (5th Cir. 2013) \\
\hline $\begin{array}{l}\text { Wilkins, } \\
\text { Christopher }\end{array}$ & $\begin{array}{l}\text { Christopher Wilkins v. } \\
\text { Stephens }\end{array}$ & $\begin{array}{l}560 \text { Fed. Appx. } 299 \text { (5th Cir. } \\
2014 \text { ) }\end{array}$ \\
\hline Wilson, David & David Wilson v. Butler & 813 F. 2d 664 (5th Cir. 1987) \\
\hline Zimmerman, Kevin & $\begin{array}{l}\text { Kevin Zimmerman v. } \\
\text { Cockrell }\end{array}$ & $\begin{array}{l}2002 \text { U.S. App. LEXIS } 28187 \\
\text { (5th Cir. 2002) }\end{array}$ \\
\hline
\end{tabular}




\section{STRICKI AND CASES IN WHICH TRIAL COUNSEL FAILED TO REQUEST MENTAL HEALTH EXPERT $(\mathrm{N}=32 / 198=16.2 \%)$}

\begin{tabular}{|c|c|c|}
\hline Defendant Name: & Title: & Case Citation: \\
\hline Baltazar, John & John Baltazar v. Cockrell & $\begin{array}{l}2002 \text { U.S. App. LEXIS } 28570 \\
\text { (5th Cir. 2002) }\end{array}$ \\
\hline Barnard, Harold & Harold Barnard v. Collins & 958 F. 2d 634 (5th Cir. 1992) \\
\hline Bishop, Dale & Dale Bishop v. Epps & $\begin{array}{l}265 \text { Fed. Appx. } 285 \text { (5th Cir. } \\
2008 \text { ) }\end{array}$ \\
\hline Brown, Arthur & Arthur Brown v. Thaler & 684 F. 3d 482 (5th Cir. 2012) \\
\hline Byrne, Edward & Edward Bryne v. Butler & 845 F. 2d 501 (5th Cir. 1988) \\
\hline Clark, Herman & Herman Clark v. Collins & 19 F. 3d 959 (5th Cir. 1994) \\
\hline Crane, Alvin & Alvin Crane v. Johnson & 178 F. 3d 309 (5th Cir. 1999) \\
\hline Drew, Robert & Robert Drew v. Collins & 964 F. 2d 411 (5th Cir. 1992) \\
\hline Druery, Marcus & Marcus Druery v. Thaler & 647 F. 3d 535 (5th Cir. 2011) \\
\hline Garza, Manuel & Manuel Garza v. Stephens & 738 F. 3d 669 (5th Cir. 2013) \\
\hline Gonzales, Ramiro & Ramiro Gonzales & $\begin{array}{l}606 \text { Fed. Appx. } 767 \text { (5th Cir. } \\
2015 \text { ) }\end{array}$ \\
\hline Gray, Rodney & Rodney Gray v. Epps & 616 F. 3d 436 (5th Cir. 2010) \\
\hline Green, Edward & Edward Green v. Cockrell & $\begin{array}{l}2003 \text { U.S. App. LEXIS } 28425 \\
\text { (5th Cir. 2003) }\end{array}$ \\
\hline Hankins, Terry & $\begin{array}{l}\text { Terry Hankins v. } \\
\text { Quarterman }\end{array}$ & $\begin{array}{l}288 \text { Fed. Appx. } 952 \text { (5th Cir. } \\
2008 \text { ) }\end{array}$ \\
\hline Jackson, Henry & Henry Jackson v. Epps & $\begin{array}{l}447 \text { Fed. Appx. } 535 \text { (5th Cir. } \\
2011 \text { ) }\end{array}$ \\
\hline Little, William & William Little v. Johnson & 162 F. 3d 855 (5th Cir. 1998) \\
\hline $\begin{array}{l}\text { Mattheson, } \\
\text { Howard } \\
\end{array}$ & $\begin{array}{l}\text { Howard Mattheson v. } \\
\text { King }\end{array}$ & 751 F. 2d 1432 (5th Cir. 1985) \\
\hline Moody, John & John Moody v. Johnson & 139 F. 3d 477 (5th Cir. 1998) \\
\hline Sawyer, Robert & Robert Sawyer v. Butler & 848 F. 2d 582 (5th Cir. 1988) \\
\hline Simmons, Gary & Gary Simmons v. Epps & $\begin{array}{l}381 \text { Fed. Appx. } 339 \text { (5th Cir. } \\
2010 \text { ) }\end{array}$ \\
\hline Smith, Roy & Roy Smith v. Quarterman & 515 F. 3d 392 (5th Cir. 2008) \\
\hline Stoker, David & David Stoker v. Scott & $\begin{array}{l}1996 \text { U.S. App. LEXIS } 42604 \\
\text { (5th Cir. 1996) }\end{array}$ \\
\hline Thompson, John & John Thompson v. Cain & 161 F. 3d 802 (5th Cir. 1998) \\
\hline $\begin{array}{l}\text { Thompson, } \\
\text { Robert }\end{array}$ & $\begin{array}{l}\text { Robert Thompson v. } \\
\text { Quarterman }\end{array}$ & $\begin{array}{l}292 \text { Fed. Appx. } 277 \text { (5th Cir. } \\
2008 \text { ) }\end{array}$ \\
\hline $\begin{array}{l}\text { Titsworth, } \\
\text { Timothy }\end{array}$ & $\begin{array}{l}\text { Timothy Titsworth v. } \\
\text { Dretke }\end{array}$ & 401 F. 3d 301 (5th Cir. 2005) \\
\hline $\begin{array}{l}\text { Van Alstyne, } \\
\text { Gregory }\end{array}$ & $\begin{array}{l}\text { Gregory Van Alstyne v. } \\
\text { Cockrell }\end{array}$ & $\begin{array}{l}2002 \text { U.S. App. LEXIS } 29069 \\
\text { (5th Cir. 2002) }\end{array}$ \\
\hline
\end{tabular}




\begin{tabular}{|l|l|l|}
\hline Valle, Yosvannis & $\begin{array}{l}\text { Yosvannis Valle v. } \\
\text { Quarterman }\end{array}$ & $\begin{array}{l}\text { 2008 U.S. App. LEXIS 22165 } \\
\text { (5th Cir. 2008) }\end{array}$ \\
\hline West, Robert & Robert West v. Johnson & 92 F. 3d 1385 (5th Cir. 1996) \\
\hline Whitaker, George & $\begin{array}{l}\text { George Whitaker v. } \\
\text { Quarterman }\end{array}$ & $\begin{array}{l}\text { 200 Fed. Appx. 351 (5th Cir. } \\
\text { 2006) }\end{array}$ \\
\hline White, Robert & Robert White v. Johnson & 153 F. 3d 197 (5th Cir. 1998) \\
\hline $\begin{array}{l}\text { Wilkerson, } \\
\text { Richard }\end{array}$ & $\begin{array}{l}\text { Richard Wilkerson v. } \\
\text { Collins }\end{array}$ & 950 F. 2d 1054 (5th Cir. 1992) \\
\hline Williams, Walter & Walter Williams v. Collins & 16 F. 3d 626 (5th Cir. 1994) \\
\hline
\end{tabular}




\section{STRICKLAND CASES IN WHICH TRIAL COUNSEL FAILED TO UTILIZE MENTAL HEALTH EXPERT $(\mathrm{N}=18 / 198=9 \%)$}

\begin{tabular}{|c|c|c|}
\hline Defendant name: & $\begin{array}{c}\text { Title: } \\
\end{array}$ & Case Citation: \\
\hline Alan, Guy & Guy Alan v. Stephens & $\begin{array}{l}\text { 619 Fed Appx. } 280 \text { (5th Cir. } \\
2015 \text { ) }\end{array}$ \\
\hline Bernard, Brandon & U.S. v. Brandon Bernard & 762 F 3d 467 (5th Cir. 2014) \\
\hline Brown, John & John Brown v. Cain & 104 F. 3d 744 (5th Cir. 1997) \\
\hline Castillo, Juan & Juan Castillo v. Stephens & $\begin{array}{l}640 \text { Fed. Appx } 283 \text { (5th Cir. } \\
2016 \text { ) }\end{array}$ \\
\hline Crawford, Charles & Charles Crawford v. Epps & $\begin{array}{l}353 \text { Fed. Appx. } 977 \text { (5th Cir. } \\
2009 \text { ) }\end{array}$ \\
\hline Dowthitt, Dennis & $\begin{array}{l}\text { Dennis Dowthitt v. } \\
\text { Johnson }\end{array}$ & 230 F. 3d 733 (5th Cir. 2000) \\
\hline $\begin{array}{l}\text { Gallamore, } \\
\text { Samuel }\end{array}$ & $\begin{array}{l}\text { Samuel Gallamore v. } \\
\text { Cockrell }\end{array}$ & $\begin{array}{l}2001 \text { U.S. App. LEXIS } 31510 \\
\text { (5th Cir. 2001) }\end{array}$ \\
\hline Gentry, Kenneth & $\begin{array}{l}\text { Kenneth Gentry v. } \\
\text { Johnson }\end{array}$ & $\begin{array}{l}1996 \text { U.S. App. LEXIS } 43513 \\
\text { (5th Cir. 1996) }\end{array}$ \\
\hline King, John & John King v. Davis & $\begin{array}{l}703 \text { Fed. Appx. } 320 \text { (5th Cir. } \\
\text { 2017) }\end{array}$ \\
\hline LaGrone, Edward & $\begin{array}{l}\text { Edward LaGrone } \mathrm{v} . \\
\text { Cockrell }\end{array}$ & $\begin{array}{l}2003 \text { U.S. App. LEXIS } 18150 \\
\text { (5th Cir. 2003) }\end{array}$ \\
\hline Lincecum, Kavin & $\begin{array}{l}\text { Kavin Lincecum v. } \\
\text { Collins }\end{array}$ & 958 F. 2d 1271 (5th Cir. 1992) \\
\hline Patterson, Kelsey & $\begin{array}{l}\text { Kelsey Patterson v. } \\
\text { Cockrell }\end{array}$ & $\begin{array}{l}\text { 2033 U.S. App. LEXIS } 28033 \\
\text { (5th Cir. 2003) }\end{array}$ \\
\hline Raby, Charles & Charles Raby v. Dretke & $\begin{array}{l}78 \text { Fed. Appx. } 324 \text { (5th Cir. } \\
\text { 2003) }\end{array}$ \\
\hline Roberts, Douglas & $\begin{array}{l}\text { Douglas Roberts v. } \\
\text { Dretke }\end{array}$ & 381 F. 3d 491 (5th Cir. 2004) \\
\hline Turner, Edwin & Edwin Turner v. Epps & $\begin{array}{l}412 \text { Fed. Appx. } 696 \text { (5th Cir. } \\
\text { 2011) }\end{array}$ \\
\hline Walbey, Gaylon & $\begin{array}{l}\text { Gaylon Walbey v. } \\
\text { Quarterman }\end{array}$ & $\begin{array}{l}309 \text { Fed. Appx. } 795 \text { (5th Cir. } \\
\text { 2009) }\end{array}$ \\
\hline Woodard, Robert & $\begin{array}{l}\text { Robert Woodard v. } \\
\text { Thaler }\end{array}$ & $\begin{array}{l}\text { 414 Fed. Appx. } 675 \text { (5th Cir. } \\
\text { 2011) }\end{array}$ \\
\hline Yowell, Michael & Michael Yowell v. Thaler & $\begin{array}{l}442 \text { Fed. Appx. } 100 \text { (5th Cir. } \\
\text { 2011) }\end{array}$ \\
\hline
\end{tabular}




\section{STRICKLAND CASES IN WHICH THERE WAS NO MITIGATION PRESENTED, AND DEFENDANT WAS ULTIMATELY EXECUTED $(\mathrm{N}=19 / 198=9.6 \%$ NO MITIGATION $)$ AND $(\mathrm{N}=14 / 19$ EXECUTIONS WHEN NO MITIGATION PRESENTED OR 73.7\%)}

\begin{tabular}{|c|c|c|}
\hline Defendant Name: & $\begin{array}{l}\text { Title: } \\
\end{array}$ & Case Citation: \\
\hline Amos, Bernard & Bernard Amos v. Scott & $\begin{array}{l}61 \text { F. 3d } 333 \text { (5th Cir. 1995) } \\
\text { executed in TX 12/6/95 }\end{array}$ \\
\hline Bishop, Dale & Dale Bishop v. Epps & $\begin{array}{l}\text { 265 Fed. Appx. } 285 \text { (5th Cir. } \\
\text { 2008) executed in MS } 7 / 23 / 08\end{array}$ \\
\hline Brawner, Jan & Jan Brawner v. Epps & $\begin{array}{l}439 \text { Fed. Appx. } 396 \text { (5th Cir. } \\
2011) \text { executed in MS in } \\
6 / 12 / 12\end{array}$ \\
\hline Cannon, Joseph & $\begin{array}{l}\text { Joseph Cannon v. } \\
\text { Johnson }\end{array}$ & $\begin{array}{l}134 \text { F. 3d } 683 \text { (5th Cir. 1998) } \\
\text { executed in TX in } 4 / 22 / 98\end{array}$ \\
\hline Faulderv, Joseph & $\begin{array}{l}\text { Joseph Faulderv v. } \\
\text { Johnson }\end{array}$ & $\begin{array}{l}81 \text { F. 3d } 515 \text { (5th Cir. 1996) } \\
\text { not executed }\end{array}$ \\
\hline Garza, Robert & Robert Garza v. Thaler & $\begin{array}{l}487 \text { Fed. Appx. } 907 \text { (5th Cir. } \\
\text { 2012) executed in TX 9/19/13 }\end{array}$ \\
\hline Gates, Bill & Bill Gates v. Davis & $\begin{array}{l}660 \text { Fed. Appx. } 270 \text { (5th Cir. } \\
\text { 2016) not executed }\end{array}$ \\
\hline Hammond, Karl & Karl Hammond v. Scott & $\begin{array}{l}1994 \text { U.S. App. LEXIS } 43045 \\
\text { (5th Cir. 1994) executed in } \\
\text { Texas } 6 / 21 / 95\end{array}$ \\
\hline Jones, Larry & Larry Jones v. Thigpen & $\begin{array}{l}788 \text { F. 2d } 1101 \text { (5th Cir. 1986) } \\
\text { reversal }\end{array}$ \\
\hline Ladd, Robert & Robert Ladd v. Cockrell & $\begin{array}{l}311 \text { F. 3d } 349 \text { (5th Cir. 2002) } \\
\text { executed in TX on } 1 / 29 / 15\end{array}$ \\
\hline Lockett, Carl & $\begin{array}{l}\text { Carl Lockett v. } \\
\text { Anderson }\end{array}$ & $\begin{array}{l}230 \text { F. 3d } 695 \text { (5th Cir. 2000) } \\
\text { reversed }\end{array}$ \\
\hline Mann, Fletcher & Fletcher Mann v. Scott & $\begin{array}{l}41 \mathrm{~F} .3 \mathrm{~d} 968 \text { (5th Cir. 1994) } \\
\text { executed in TX } 6 / 1 / 95\end{array}$ \\
\hline Mattheson, Howard & $\begin{array}{l}\text { Howard Mattheson v. } \\
\text { King }\end{array}$ & $\begin{array}{l}751 \text { F. 2d } 1432 \text { (5th Cir. 1985) } \\
\text { not executed }\end{array}$ \\
\hline Roberts, Douglas & $\begin{array}{l}\text { Douglas Roberts v. } \\
\text { Dretke }\end{array}$ & $\begin{array}{l}381 \text { F. 3d } 491 \text { (5th Cir. 2004) } \\
\text { executed in TX on } 4 / 20 / 05\end{array}$ \\
\hline Shore, Anthony & Anthony Shore v. Davis & $\begin{array}{l}845 \text { F. 3d } 627 \text { ( } 5 \text { th Cir. 2017) } \\
\text { executed in TX on } 1 / 8 / 18\end{array}$ \\
\hline Smith, Charles & $\begin{array}{l}\text { Charles Smith v. } \\
\text { Quarterman }\end{array}$ & $\begin{array}{l}471 \mathrm{~F} .3 \mathrm{~d} 565(5 \text { th Cir. 2006) } \\
\text { executed in TX on } 9 / 16 / 01\end{array}$ \\
\hline West, Robert & Robert West v. Johnson & $\begin{array}{l}92 \text { F. 3d } 1385 \text { (5th Cir. 1996) } \\
\text { executed in TX on } 7 / 29 / 97\end{array}$ \\
\hline Williams, Dobie & Dobie Williams v. Cain & $\begin{array}{l}125 \text { F. 3d } 269 \text { (5th Cir. 1997) } \\
\text { executed in LA on } 1 / 8 / 99\end{array}$ \\
\hline Williams, Walter & $\begin{array}{l}\text { Walter Williams v. } \\
\text { Collins }\end{array}$ & $\begin{array}{l}16 \text { F. 3d } 626 \text { (5th Cir. 1994) } \\
\text { executed in TX on } 10 / 5 / 94\end{array}$ \\
\hline
\end{tabular}


7. STRICKLAND CASES IN WHICH DEFENDANT HAS BEEN EXECUTED $(\mathrm{N}=123 / 198$ OR $62.12 \%$ OF ENTIRE SAMPLE OR $123 / 185$ OR $66.48 \%$ OF THE AFFIRMANCES)

\begin{tabular}{|c|c|c|c|c|}
\hline $\begin{array}{c}\text { Defendant } \\
\text { name: }\end{array}$ & Title: & Case citation: & $\begin{array}{c}\text { Date } \\
\text { executed }\end{array}$ & State: \\
\hline $\begin{array}{l}\text { Adanandus, } \\
\text { Dwight }\end{array}$ & $\begin{array}{l}\text { Dwight } \\
\text { Adanandus v. } \\
\text { Johnson }\end{array}$ & $\begin{array}{l}\text { 1997 U.S. App. } \\
\text { LEXIS } 43223 \\
\text { (5th Cir. 1997) }\end{array}$ & $10 / 01 / 1997$ & $\mathrm{TX}$ \\
\hline $\begin{array}{l}\text { Alexander, } \\
\text { Gut }\end{array}$ & $\begin{array}{l}\text { Gut Alexander v. } \\
\text { Quarterman }\end{array}$ & $\begin{array}{l}198 \text { Fed. Appx. } \\
354 \text { (5th Cir. } \\
2006)\end{array}$ & N/A & TX \\
\hline Alan, Guy & $\begin{array}{l}\text { Guy Alan v. } \\
\text { Stephens }\end{array}$ & $\begin{array}{l}619 \text { Fed Appx. } \\
280 \text { (5th Cir. } \\
2015 \text { ) }\end{array}$ & $\mathrm{N} / \mathrm{A}$ & TX \\
\hline $\begin{array}{l}\text { Amos, } \\
\text { Bernard }\end{array}$ & $\begin{array}{l}\text { Bernard Amos v. } \\
\text { Scott }\end{array}$ & $\begin{array}{l}61 \text { F. 3d } 333 \\
(5 \text { th Cir. 1995) }\end{array}$ & $12 / 06 / 1995$ & $\mathrm{TX}$ \\
\hline $\begin{array}{l}\text { Anderson, } \\
\text { Larry }\end{array}$ & $\begin{array}{l}\text { Larry Anderson } \\
\text { v. Collins }\end{array}$ & $\begin{array}{l}\text { 18 F. 3d } 1208 \\
\text { (5th Cir. 1994) }\end{array}$ & $04 / 26 / 1994$ & $\mathrm{TX}$ \\
\hline $\begin{array}{l}\text { Andrews, } \\
\text { Maurice }\end{array}$ & $\begin{array}{l}\text { Maurice Andrews } \\
\text { v. Collins }\end{array}$ & $\begin{array}{l}\text { 21 F. 3d } 612 \\
\text { (5th Cir. 1994) }\end{array}$ & $\mathrm{N} / \mathrm{A}$ & $\mathrm{TX}$ \\
\hline Austin, Perry & $\begin{array}{l}\text { Perry Austin v. } \\
\text { Davis }\end{array}$ & $\begin{array}{l}876 \text { F. 3d } 757 \\
\text { (5th Cir. 2017) }\end{array}$ & $\mathrm{N} / \mathrm{A}$ & TX \\
\hline $\begin{array}{l}\text { Avila, } \\
\text { Rigoberto }\end{array}$ & $\begin{array}{l}\text { Rigoberto Avila v. } \\
\text { Quarterman }\end{array}$ & $\begin{array}{l}560 \text { F. 3d } 299 \\
\text { (5th Cir. 2009) }\end{array}$ & N/A & TX \\
\hline $\begin{array}{l}\text { Ayesta, } \\
\text { Carlos }\end{array}$ & $\begin{array}{l}\text { Carlos Ayesta v. } \\
\text { Stephens }\end{array}$ & $\begin{array}{l}817 \text { F. 3d } 888 \\
\text { (5th Cir. 2016) }\end{array}$ & $\mathrm{N} / \mathrm{A}$ & TX \\
\hline $\begin{array}{l}\text { Baltazar, } \\
\text { John }\end{array}$ & $\begin{array}{l}\text { John Baltazar v. } \\
\text { Cockrell }\end{array}$ & $\begin{array}{l}\text { 2002 U.S. App. } \\
\text { LEXIS } 28570 \\
\text { (5th Cir. 2002) }\end{array}$ & $01 / 15 / 2003$ & TX \\
\hline $\begin{array}{l}\text { Banks, } \\
\text { Delma }\end{array}$ & $\begin{array}{l}\text { Delma Banks v. } \\
\text { Cockrell }\end{array}$ & $\begin{array}{l}2002 \text { U.S. App. } \\
\text { LEXIS 28401 } \\
\text { (5th Gir. 2002) }\end{array}$ & $\mathrm{N} / \mathrm{A}$ & $\mathrm{TX}$ \\
\hline $\begin{array}{l}\text { Barbee, } \\
\text { Stephen }\end{array}$ & $\begin{array}{l}\text { Stephen Barbee } \\
\text { v. Davis }\end{array}$ & $\begin{array}{l}660 \text { Fed. Appx. } \\
293 \text { (5th Cir. } \\
2016)\end{array}$ & $\mathrm{N} / \mathrm{A}$ & $\mathrm{TX}$ \\
\hline $\begin{array}{l}\text { Barnard, } \\
\text { Harold }\end{array}$ & $\begin{array}{l}\text { Harold Barnard } \\
\text { v. Collins }\end{array}$ & $\begin{array}{l}958 \text { F. 2d } 634 \\
\text { (5th Cir. 1992) }\end{array}$ & $02 / 02 / 1994$ & TX \\
\hline $\begin{array}{l}\text { Battaglia, } \\
\text { John }\end{array}$ & $\begin{array}{l}\text { John Battaglia v. } \\
\text { Stephens }\end{array}$ & $\begin{array}{l}621 \text { Fed. Appx. } \\
781 \text { (5th } \\
\text { Cir.2015) } \\
\end{array}$ & $02 / 01 / 2018$ & $\mathrm{TX}$ \\
\hline Beets, Betty & $\begin{array}{l}\text { Betty Beets v. } \\
\text { Collins }\end{array}$ & $\begin{array}{l}986 \text { F. 2d } 1478 \\
\text { (5th Cir. 1993) }\end{array}$ & $02 / 24 / 2000$ & TX \\
\hline $\begin{array}{l}\text { Bell, } \\
\text { Frederick }\end{array}$ & $\begin{array}{l}\text { Frederick Bell v. } \\
\text { Epps }\end{array}$ & $\begin{array}{l}347 \text { Fed. Appx. } \\
73 \text { 5th Cir. } \\
(2009)\end{array}$ & N/A & MS \\
\hline Bell, Walter & $\begin{array}{l}\text { Walter Bell v. } \\
\text { Lynaugh }\end{array}$ & $\begin{array}{l}828 \text { F. } 2 d 1085 \\
\text { (5th Cir. 1987) }\end{array}$ & $\mathrm{N} / \mathrm{A}$ & TX \\
\hline $\begin{array}{l}\text { Belyeu, } \\
\text { Clifton }\end{array}$ & $\begin{array}{l}\text { Clifton Belyeu v. } \\
\text { Scott }\end{array}$ & $\begin{array}{l}\text { 67. F. 3d } 535 \\
\text { (5th Cir. 1995) }\end{array}$ & $05 / 16 / 1997$ & $\mathrm{TX}$ \\
\hline Bishop, Dale & $\begin{array}{l}\text { Dale Bishop v. } \\
\text { Epps }\end{array}$ & $\begin{array}{l}265 \text { Fed. Appx. } \\
285 \text { (5th Cir. }\end{array}$ & $07 / 23 / 2008$ & MS \\
\hline
\end{tabular}




\begin{tabular}{|c|c|c|c|c|}
\hline & & 2008) & & \\
\hline $\begin{array}{l}\text { Black, } \\
\text { Robert }\end{array}$ & $\begin{array}{l}\text { Robert Black v. } \\
\text { Collins }\end{array}$ & $\begin{array}{l}962 \text { F. 2d } 394 \\
\text { (5th Cir. 1992) }\end{array}$ & $05 / 22 / 1992$ & $\overline{T X}$ \\
\hline $\begin{array}{l}\text { Blanton, } \\
\text { Reginald } \\
\end{array}$ & $\begin{array}{l}\text { Reginald Blanton } \\
\text { v. Quarterman }\end{array}$ & $\begin{array}{l}543 \text { F. } 3 d 230 \\
\text { (5th Cir. 2008) }\end{array}$ & $10 / 27 / 2009$ & TX \\
\hline $\begin{array}{l}\text { Boyd, } \\
\text { Charles }\end{array}$ & $\begin{array}{l}\text { Charles Boyd v. } \\
\text { Johnson }\end{array}$ & $\begin{array}{l}167 \text { F. 3d } 907 \\
\text { (5th Cir. 1999) }\end{array}$ & $08 / 05 / 1999$ & $\mathrm{TX}$ \\
\hline $\begin{array}{l}\text { Boyle, } \\
\text { Herbert }\end{array}$ & $\begin{array}{l}\text { Herbert Boyle v. } \\
\text { Johnson }\end{array}$ & $\begin{array}{l}93 \mathrm{~F} .3 \mathrm{~d} 180 \\
\text { (5th Cir. } 1996 \text { ) }\end{array}$ & $\mathrm{N} / \mathrm{A}$ & $\mathrm{TX}$ \\
\hline Braziel, Alvin & $\begin{array}{l}\text { Alvin Braziel v. } \\
\text { Stephens }\end{array}$ & $\begin{array}{l}631 \text { Fed. Appx. } \\
225 \text { (5th Cir. } \\
2015 \text { ) }\end{array}$ & $12 / 11 / 2018$ & TX \\
\hline Brawner, Jan & $\begin{array}{l}\text { Jan Brawner v. } \\
\text { Epps }\end{array}$ & $\begin{array}{l}439 \text { Fed. Appx. } \\
396 \text { (5th Cir. } \\
2011 \text { ) }\end{array}$ & $06 / 12 / 2012$ & MS \\
\hline $\begin{array}{l}\text { Brown, } \\
\text { Arthur }\end{array}$ & $\begin{array}{l}\text { Arthur Brown v. } \\
\text { Thaler }\end{array}$ & $\begin{array}{l}\text { 684 F. 3d } 482 \\
\text { (5th Cir. 2012) }\end{array}$ & $\mathrm{N} / \mathrm{A}$ & TX \\
\hline Brown, John & $\begin{array}{l}\text { John Brown v. } \\
\text { Cain }\end{array}$ & $\begin{array}{l}104 \text { F. 3d } 744 \\
\text { (5th Cir. 1997) }\end{array}$ & $04 / 24 / 1997$ & LA \\
\hline $\begin{array}{l}\text { Byrne, } \\
\text { Edward }\end{array}$ & $\begin{array}{l}\text { Edward Byrne v. } \\
\text { Butler }\end{array}$ & $\begin{array}{l}845 \text { F. 2d 501 } \\
\text { (5th Cir. 1988) }\end{array}$ & $\mathrm{N} / \mathrm{A}$ & $\overline{\text { LA }}$ \\
\hline $\begin{array}{l}\text { Cannon, } \\
\text { Joseph }\end{array}$ & $\begin{array}{l}\text { Joseph Cannon v. } \\
\text { Johnson }\end{array}$ & $\begin{array}{l}134 \text { F. 3d } 683 \\
\text { (5th Cir. 1998) }\end{array}$ & $04 / 22 / 1998$ & $\mathrm{TX}$ \\
\hline Cantu, Ivan & $\begin{array}{l}\text { Ivan Cantu v. } \\
\text { Thaler }\end{array}$ & $\begin{array}{l}632 \text { F. 3d } 157 \\
\text { (5th Cir. 2011) }\end{array}$ & $\mathrm{N} / \mathrm{A}$ & TX \\
\hline $\begin{array}{l}\text { Cantu, } \\
\text { Ruben }\end{array}$ & $\begin{array}{l}\text { Ruben Cantu v. } \\
\text { Collins }\end{array}$ & $\begin{array}{l}967 \text { F. 2d } 1006 \\
\text { (5th Cir. 1992) }\end{array}$ & $08 / 23 / 1993$ & $\mathrm{TX}$ \\
\hline $\begin{array}{l}\text { Carter, } \\
\text { Robert } \\
\end{array}$ & $\begin{array}{l}\text { Robert Carter v. } \\
\text { Johnson }\end{array}$ & $\begin{array}{l}\text { 131 F. 3d 452 } \\
\text { (5th Cir. 1997) }\end{array}$ & $05 / 31 / 2000$ & $\mathrm{TX}$ \\
\hline Castillo, Juan & $\begin{array}{l}\text { Juan Castillo v. } \\
\text { Stephens }\end{array}$ & $\begin{array}{l}640 \text { Fed. Appx } \\
283 \text { (5th Cir. } \\
2016 \text { ) }\end{array}$ & $05 / 16 / 2018$ & $\mathrm{TX}$ \\
\hline $\begin{array}{l}\text { Celestine, } \\
\text { Willie }\end{array}$ & $\begin{array}{l}\text { Willie Celestine v. } \\
\text { Blackburn }\end{array}$ & $\begin{array}{l}750 \text { F. 2d } 353 \\
\text { (5th Gir. 1984) }\end{array}$ & $07 / 20 / 1987$ & LA \\
\hline $\begin{array}{l}\text { Charles, } \\
\text { Derrick } \\
\end{array}$ & $\begin{array}{l}\text { Derrick Charles } \\
\text { v. Stephens }\end{array}$ & $\begin{array}{l}736 \text { F. 3d } 380 \\
\text { (5th Cir. 2013) }\end{array}$ & $05 / 12 / 2015$ & $\mathrm{TX}$ \\
\hline Chase, Ricky & $\begin{array}{l}\text { Rickey Chase v. } \\
\text { Epps }\end{array}$ & $\begin{array}{l}83 \text { Fed. Appx. } \\
673 \text { (5th Cir. } \\
2003 \text { ) }\end{array}$ & $\mathrm{N} / \mathrm{A}$ & MS \\
\hline Clark, David & $\begin{array}{l}\text { David Clark v. } \\
\text { Collins }\end{array}$ & $\begin{array}{l}756 \text { F. 2d } 68 \\
(1992)\end{array}$ & $02 / 28 / 1992$ & $\mathrm{TX}$ \\
\hline $\begin{array}{l}\text { Clark, } \\
\text { Herman } \\
\end{array}$ & $\begin{array}{l}\text { Herman Clark v. } \\
\text { Collins }\end{array}$ & $\begin{array}{l}19 \text { F. 3d } 959 \\
(1994)\end{array}$ & $10 / 06 / 1994$ & TX \\
\hline Coble, Billie & $\begin{array}{l}\text { Billie Coble v. } \\
\text { Davis }\end{array}$ & $\begin{array}{l}682 \text { Fed. Appx } \\
261 \text { (2017) } \\
\end{array}$ & $\mathrm{N} / \mathrm{A}$ & $\mathrm{TX}$ \\
\hline $\begin{array}{l}\text { Cockrell, } \\
\text { Timothy }\end{array}$ & $\begin{array}{l}\text { Timothy Cockrell } \\
\text { v. Dretke }\end{array}$ & $\begin{array}{l}88 \text { Fed. Appx } \\
34 \text { (5th Cir. } \\
2004)\end{array}$ & $\mathrm{N} / \mathrm{A}$ & $\mathrm{TX}$ \\
\hline $\begin{array}{l}\text { Cockrum, } \\
\text { John }\end{array}$ & $\begin{array}{l}\text { John Cockrum v. } \\
\text { Johnson }\end{array}$ & $\begin{array}{l}\text { 119 F. 3d } 297 \\
\text { (5th Cir. 1997) }\end{array}$ & $09 / 30 / 1997$ & $\mathrm{TX}$ \\
\hline $\begin{array}{l}\text { Coleman, } \\
\text { Lisa }\end{array}$ & $\begin{array}{l}\text { Lisa Coleman v. } \\
\text { Thaler }\end{array}$ & $\begin{array}{l}716 \text { F. 3d } 895 \\
\text { (5th Cir. 2013) }\end{array}$ & $09 / 17 / 2014$ & $\mathrm{TX}$ \\
\hline $\begin{array}{l}\text { Conner, } \\
\text { Ronnie } \\
\end{array}$ & $\begin{array}{l}\text { Ronnie Conner v. } \\
\text { Epps }\end{array}$ & $\begin{array}{l}2002 \text { U.S. App } \\
\text { LEXIS } 29673\end{array}$ & $\mathrm{~N} / \mathrm{A}$ & MS \\
\hline
\end{tabular}




\begin{tabular}{|c|c|c|c|c|}
\hline & & (5th Cir. 2002) & & \\
\hline Crane, Alvin & $\begin{array}{l}\text { Alvin Crane v. } \\
\text { Johnson }\end{array}$ & $\begin{array}{l}178 \text { F. 3d 309 } \\
\text { (5th Cir. 1999) }\end{array}$ & $10 / 12 / 1999$ & $\mathrm{TX}$ \\
\hline $\begin{array}{l}\text { Crawford, } \\
\text { Charles }\end{array}$ & $\begin{array}{l}\text { Charles Crawford } \\
\text { v. Epps }\end{array}$ & $\begin{array}{l}353 \text { Fed. Appx. } \\
977 \text { (5th Cir. } \\
2009)\end{array}$ & $\mathrm{N} / \mathrm{A}$ & MS \\
\hline $\begin{array}{l}\text { Crutsinger, } \\
\text { Billy }\end{array}$ & $\begin{array}{l}\text { Billy Crutsinger v. } \\
\text { Stephens }\end{array}$ & $\begin{array}{l}576 \text { Fed. App. } \\
422 \text { (5th Cir. } \\
2014 \text { ) }\end{array}$ & $\mathrm{N} / \mathrm{A}$ & $\mathrm{TX}$ \\
\hline Devoe, Paul & $\begin{array}{l}\text { Paul Devoe v. } \\
\text { Davis }\end{array}$ & $\begin{array}{l}2018 \text { U.S. App } \\
\text { LEXIS } 514 \\
\text { (5th Cir. 2018) }\end{array}$ & $\mathrm{N} / \mathrm{A}$ & $\mathrm{TX}$ \\
\hline $\begin{array}{l}\text { Dowthitt, } \\
\text { Dennis }\end{array}$ & $\begin{array}{l}\text { Dennis Dowthitt } \\
\text { v. Johnson }\end{array}$ & $\begin{array}{l}230 \text { F. } 3 d 733 \\
(5 \text { th Gir. 2000) }\end{array}$ & $03 / 07 / 2001$ & TX \\
\hline Drew, Robert & $\begin{array}{l}\text { Robert Drew v. } \\
\text { Collins }\end{array}$ & $\begin{array}{l}964 \text { F. 2d } 411 \\
\text { (5th Cir. 1992) }\end{array}$ & $08 / 02 / 1994$ & TX \\
\hline $\begin{array}{l}\text { Druery, } \\
\text { Marcus }\end{array}$ & $\begin{array}{l}\text { Marcus Druery v. } \\
\text { Thaler }\end{array}$ & $\begin{array}{l}647 \text { F. 3d 535 } \\
\text { (5th Cir. 2011) }\end{array}$ & N/A & $\mathrm{TX}$ \\
\hline $\begin{array}{l}\text { Enriguez, } \\
\text { Juan }\end{array}$ & $\begin{array}{l}\text { Juan Enrigues v. } \\
\text { Procunier }\end{array}$ & $\begin{array}{l}\text { 752 F. 2d } 111 \\
\text { (5th Cir. 1984) }\end{array}$ & $\mathrm{N} / \mathrm{A}$ & $\mathrm{TX}$ \\
\hline $\begin{array}{l}\text { Escamilla, } \\
\text { Licho }\end{array}$ & $\begin{array}{l}\text { Licho Escamilla } \\
\text { v. Stephens }\end{array}$ & $\begin{array}{l}602 \text { Fed. Appx. } \\
939 \text { (5th Cir. } \\
2015)\end{array}$ & $10 / 14 / 2015$ & $\overline{T X}$ \\
\hline $\begin{array}{l}\text { Esparza, } \\
\text { Guadalupe }\end{array}$ & $\begin{array}{l}\text { Guadalupe } \\
\text { Esparza v. Thaler }\end{array}$ & $\begin{array}{l}408 \text { Fed. Appx. } \\
787 \text { (5th Cir. } \\
2010)\end{array}$ & $11 / 16 / 2011$ & $\mathrm{TX}$ \\
\hline $\begin{array}{l}\text { Evans, } \\
\text { Connie }\end{array}$ & $\begin{array}{l}\text { Connie Evans v. } \\
\text { Cabana }\end{array}$ & $\begin{array}{l}821 \text { F. } 2 d 1065 \\
\text { (5th Cir. 1987) }\end{array}$ & $10 / 08 / 1987$ & MS \\
\hline $\begin{array}{l}\text { Faulderv, } \\
\text { Joseph }\end{array}$ & $\begin{array}{l}\text { Joseph Faulderv } \\
\text { v. Johnson }\end{array}$ & $\begin{array}{l}81 \text { F. 3d } 515 \\
\text { (5th Cir. 1996) }\end{array}$ & $\mathrm{N} / \mathrm{A}$ & TX \\
\hline Felde, Wayne & $\begin{array}{l}\text { Wayne Felde v. } \\
\text { Butler }\end{array}$ & $\begin{array}{l}817 \text { F. 2d } 281 \\
\text { (5th Cir. 1987) }\end{array}$ & $03 / 15 / 1988$ & LA \\
\hline $\begin{array}{l}\text { Feldman, } \\
\text { Douglas }\end{array}$ & $\begin{array}{l}\text { Douglas Feldman } \\
\text { v. Thaler }\end{array}$ & $\begin{array}{l}695 \text { F. 3d } 372 \\
\text { (5th Cir. 2012) }\end{array}$ & $07 / 31 / 2013$ & $\mathrm{TX}$ \\
\hline $\begin{array}{l}\text { Flores, } \\
\text { Andrew }\end{array}$ & $\begin{array}{l}\text { Andrew Flores v. } \\
\text { Dretke }\end{array}$ & $\begin{array}{l}82 \text { Fed. Appx. } \\
92 \text { (5th Cir. } \\
2003 \text { ) }\end{array}$ & $10 / 21 / 2004$ & $\mathrm{TX}$ \\
\hline $\begin{array}{l}\text { Flores, } \\
\text { Charles } \\
\end{array}$ & $\begin{array}{l}\text { Charles Flores v. } \\
\text { Stephens }\end{array}$ & $\begin{array}{l}794 \text { F. 3d } 494 \\
\text { (5th Cir. 2015) }\end{array}$ & $\mathrm{N} / \mathrm{A}$ & TX \\
\hline Foster, Ron & $\begin{array}{l}\text { Ron Foster v. } \\
\text { Johnson }\end{array}$ & $\begin{array}{l}293 \text { F. 3d } 766 \\
\text { (5th Cir. 2002) }\end{array}$ & N/A & $\overline{\mathrm{TX}}$ \\
\hline $\begin{array}{l}\text { Freeman, } \\
\text { James }\end{array}$ & $\begin{array}{l}\text { James Freeman v. } \\
\text { Stephens }\end{array}$ & $\begin{array}{l}614 \text { Fed. Appx. } \\
180 \text { (5th Cir. } \\
2015 \text { ) }\end{array}$ & $01 / 27 / 2016$ & $\mathrm{TX}$ \\
\hline $\begin{array}{l}\text { Gallamore, } \\
\text { Samuel }\end{array}$ & $\begin{array}{l}\text { Samuel } \\
\text { Gallamore v. } \\
\text { Cockrell } \\
\end{array}$ & $\begin{array}{l}\text { 2001 U.S. App. } \\
\text { LEXIS } 31510 \\
\text { (5th Cir. 2001) }\end{array}$ & $01 / 14 / 2003$ & $\mathrm{TX}$ \\
\hline $\begin{array}{l}\text { Garza, } \\
\text { Manuel } \\
\end{array}$ & $\begin{array}{l}\text { Manuel Garza v. } \\
\text { Stephens }\end{array}$ & $\begin{array}{l}738 \text { F. 3d } 669 \\
(5 \text { th Cir. 2013) }\end{array}$ & $04 / 15 / 2015$ & $\mathrm{TX}$ \\
\hline $\begin{array}{l}\text { Garza, } \\
\text { Robert }\end{array}$ & $\begin{array}{l}\text { Robert Garza v. } \\
\text { Thaler }\end{array}$ & $\begin{array}{l}487 \text { Fed. Appx. } \\
907 \text { (5th Cir. } \\
2012 \text { ) }\end{array}$ & $09 / 09 / 2013$ & TX \\
\hline Gates, Bill & Bill Gates v. Davis & $\begin{array}{l}660 \text { Fed. Appx. } \\
270 \text { (5th Cir. }\end{array}$ & $\mathrm{N} / \mathrm{A}$ & $\mathrm{TX}$ \\
\hline
\end{tabular}




\begin{tabular}{|c|c|c|c|c|}
\hline & & 2016) & & \\
\hline $\begin{array}{l}\text { Gentry, } \\
\text { Kenneth }\end{array}$ & $\begin{array}{l}\text { Kenneth Gentry } \\
\text { v. Johnson }\end{array}$ & $\begin{array}{l}1996 \text { U.S. App. } \\
\text { LEXIS } 43513 \\
\text { (5th Cir. 1996) }\end{array}$ & $04 / 16 / 1997$ & TX \\
\hline $\begin{array}{l}\text { Gonzales, } \\
\text { Ramiro }\end{array}$ & $\begin{array}{l}\text { Ramiro Gonzales } \\
\text { v. Stephens }\end{array}$ & $\begin{array}{l}606 \text { Fed. Appx. } \\
767 \text { (5th Cir. } \\
2015 \text { ) }\end{array}$ & $\mathrm{N} / \mathrm{A}$ & TX \\
\hline $\begin{array}{l}\text { Green, } \\
\text { Dominique }\end{array}$ & $\begin{array}{l}\text { Dominique } \\
\text { Green v. Dretke }\end{array}$ & $\begin{array}{l}\text { 82 Fed. Appx. } \\
333 \text { (5th Cir. } \\
2003 \text { ) }\end{array}$ & $10 / 26 / 2004$ & $\mathrm{TX}$ \\
\hline $\begin{array}{l}\text { Green, } \\
\text { Edward }\end{array}$ & $\begin{array}{l}\text { Edward Green v. } \\
\text { Cockrell }\end{array}$ & $\begin{array}{l}2003 \text { U.S. App. } \\
\text { LEXIS } 28425 \\
\text { (5th Cir. 2003) }\end{array}$ & $10 / 05 / 2004$ & TX \\
\hline Green, Ricky & $\begin{array}{l}\text { Ricky Green v. } \\
\text { Johnson }\end{array}$ & $\begin{array}{l}116 \text { F. 3d } 1115 \\
\text { (5th Cir. 1997) }\end{array}$ & $10 / 08 / 1997$ & TX \\
\hline $\begin{array}{l}\text { Gray, } \\
\text { Rodney }\end{array}$ & $\begin{array}{l}\text { Rodney Gray v. } \\
\text { Epps }\end{array}$ & $\begin{array}{l}616 \text { F. 3d } 436 \\
\text { (5th Cir. 2010) }\end{array}$ & $05 / 17 / 2011$ & MS \\
\hline $\begin{array}{l}\text { Guevara, } \\
\text { Gilmar }\end{array}$ & $\begin{array}{l}\text { Gilmar Guevara } \\
\text { v. Stephens }\end{array}$ & $\begin{array}{l}577 \text { Fed. Appx. } \\
364 \text { (5th Cir. } \\
\text { 2014) }\end{array}$ & $\mathrm{N} / \mathrm{A}$ & $\mathrm{TX}$ \\
\hline $\begin{array}{l}\text { Hammond, } \\
\text { Karl }\end{array}$ & $\begin{array}{l}\text { Karl Hammond } \\
\text { v. Scott }\end{array}$ & $\begin{array}{l}\text { 1994 U.S. App. } \\
\text { LEXIS } 43045 \\
\text { (1994) }\end{array}$ & $06 / 21 / 1995$ & $\mathrm{TX}$ \\
\hline $\begin{array}{l}\text { Hankins, } \\
\text { Terry }\end{array}$ & $\begin{array}{l}\text { Terry Hankins v. } \\
\text { Quarterman }\end{array}$ & $\begin{array}{l}288 \text { Fed. Appx. } \\
952 \text { (5th Cir. } \\
2008 \text { ) }\end{array}$ & $06 / 02 / 2009$ & $\mathrm{TX}$ \\
\hline Harris, David & $\begin{array}{l}\text { David Harris v. } \\
\text { Cockrell }\end{array}$ & $\begin{array}{l}313 \text { F. 3d } 238 \\
\text { (5th Cir. 2002) }\end{array}$ & $06 / 30 / 2004$ & TX \\
\hline $\begin{array}{l}\text { Hernandez, } \\
\text { Rogelio }\end{array}$ & $\begin{array}{l}\text { Rogelio } \\
\text { Hernandez v. } \\
\text { Johnson }\end{array}$ & $\begin{array}{l}1997 \text { U.S. App. } \\
\text { LEXIS } 12686 \\
\text { (5th Cir. 1997) }\end{array}$ & $\mathrm{N} / \mathrm{A}$ & TX \\
\hline $\begin{array}{l}\text { Hoffman, } \\
\text { Jessie }\end{array}$ & $\begin{array}{l}\text { Jessie Hoffman v. } \\
\text { Cain }\end{array}$ & $\begin{array}{l}752 \text { F. 3d } 430 \\
\text { (5th Cir. 2014) }\end{array}$ & $\mathrm{N} / \mathrm{A}$ & $\mathrm{TX}$ \\
\hline $\begin{array}{l}\text { Hood, } \\
\text { Charles }\end{array}$ & $\begin{array}{l}\text { Charles Hood v. } \\
\text { Dretke }\end{array}$ & $\begin{array}{l}93 \text { Fed. Appx. } \\
665 \text { (5th Cir. } \\
2004)\end{array}$ & $\mathrm{N} / \mathrm{A}$ & TX \\
\hline $\begin{array}{l}\text { Hudson, } \\
\text { Robert }\end{array}$ & $\begin{array}{l}\text { Robert Hudson v. } \\
\text { Quarterman }\end{array}$ & $\begin{array}{l}273 \text { Fed. Appx. } \\
331 \text { (5th Cir. } \\
2008 \text { ) }\end{array}$ & $11 / 20 / 2008$ & TX \\
\hline $\begin{array}{l}\text { Jackson, } \\
\text { Henry }\end{array}$ & $\begin{array}{l}\text { Henry Jackson v. } \\
\text { Epps }\end{array}$ & $\begin{array}{l}447 \text { Fed. Appx. } \\
535 \text { (5th Cir. } \\
2011 \text { ) }\end{array}$ & $06 / 05 / 2012$ & $\overline{\mathrm{MS}}$ \\
\hline $\begin{array}{l}\text { Jennings, } \\
\text { Robert }\end{array}$ & $\begin{array}{l}\text { Robert Jennings } \\
\text { v. Stephens }\end{array}$ & $\begin{array}{l}\text { 537 Fed. } \\
\text { Appx. } 326 \text { (5th } \\
\text { Cir. 2013) } \\
\end{array}$ & $01 / 30 / 2019$ & TX \\
\hline $\begin{array}{l}\text { Johnson, } \\
\text { Edward }\end{array}$ & $\begin{array}{l}\text { Edward Johnson } \\
\text { v. Cabana }\end{array}$ & $\begin{array}{l}818 \text { F. 2d } 333 \\
\text { (5th Cir. 1987) }\end{array}$ & $05 / 20 / 1987$ & MS \\
\hline $\begin{array}{l}\text { Johnson, } \\
\text { Michael } \\
\end{array}$ & $\begin{array}{l}\text { Michael Johnson } \\
\text { v. Cockrell }\end{array}$ & $\begin{array}{l}306 \text { F. 3d } 249 \\
\text { (5th Cir. 2002) }\end{array}$ & $\mathrm{N} / \mathrm{A}$ & $\mathrm{TX}$ \\
\hline Jones, Anzel & $\begin{array}{l}\text { Anzel Jones v. } \\
\text { Cockrell }\end{array}$ & $\begin{array}{l}74 \text { Fed. Appx. } \\
317 \text { (5th Cir. } \\
2003 \text { ) }\end{array}$ & $\mathrm{N} / \mathrm{A}$ & $\mathrm{TX}$ \\
\hline $\begin{array}{l}\text { Jordan, } \\
\text { Richard }\end{array}$ & $\begin{array}{l}\text { Richard Jordan v. } \\
\text { Epps }\end{array}$ & $\begin{array}{l}756 \text { F. 3d } 395 \\
\text { (5th Cir. 2014) }\end{array}$ & $\mathrm{N} / \mathrm{A}$ & MS \\
\hline
\end{tabular}




\begin{tabular}{|c|c|c|c|c|}
\hline King, John & $\begin{array}{l}\text { John King v. } \\
\text { Davis }\end{array}$ & $\begin{array}{l}703 \text { Fed. Appx. } \\
320 \text { (5th Cir. } \\
2017 \text { ) }\end{array}$ & $\mathrm{N} / \mathrm{A}$ & $\mathrm{TX}$ \\
\hline King, Mack & $\begin{array}{l}\text { Mack King v. } \\
\text { Puckett }\end{array}$ & $\begin{array}{l}1 \text { F. 3d } 280 \\
\text { (5th Cir. 1993) }\end{array}$ & N/A & MS \\
\hline $\begin{array}{l}\text { Kitchens, } \\
\text { William }\end{array}$ & $\begin{array}{l}\text { William Kitchens } \\
\text { v. Johnson }\end{array}$ & $\begin{array}{l}190 \text { F. 3d } 698 \\
\text { (5th Cir. 1999) }\end{array}$ & $05 / 09 / 2000$ & TX \\
\hline $\begin{array}{l}\text { Knight, } \\
\text { Patrick }\end{array}$ & $\begin{array}{l}\text { Patrick Knight v. } \\
\text { Quarterman }\end{array}$ & $\begin{array}{l}186 \text { Fed. Appx. } \\
518 \text { (5th Cir. } \\
2006 \text { ) }\end{array}$ & $06 / 26 / 2007$ & TX \\
\hline Kunkle, Troy & $\begin{array}{l}\text { Troy Kunkle v. } \\
\text { Dretke }\end{array}$ & $\begin{array}{l}352 \text { F. 3d } 980 \\
\text { (5th Cir. 2003) }\end{array}$ & $01 / 25 / 2005$ & TX \\
\hline Kyles, Curtis & $\begin{array}{l}\text { Curtis Kyles v. } \\
\text { Whitley }\end{array}$ & $\begin{array}{l}5 \text { F. 3d } 806 \\
\text { (5th Cir. 1993) }\end{array}$ & $\mathrm{N} / \mathrm{A}$ & $\mathrm{TX}$ \\
\hline Ladd, Robert & $\begin{array}{l}\text { Robert Ladd v. } \\
\text { Cockrell }\end{array}$ & $\begin{array}{l}311 \text { F. 3d } 349 \\
\text { (5th Cir. 2002) }\end{array}$ & $01 / 29 / 2015$ & TX \\
\hline $\begin{array}{l}\text { LaGrone, } \\
\text { Edward }\end{array}$ & $\begin{array}{l}\text { Edward LaGrone } \\
\text { v. Cockrell }\end{array}$ & $\begin{array}{l}2003 \text { U.S. App. } \\
\text { LEXIS } 18150 \\
\text { (5th Cir. 2003) }\end{array}$ & $02 / 11 / 2004$ & TX \\
\hline $\begin{array}{l}\text { Lincecum, } \\
\text { Kavin }\end{array}$ & $\begin{array}{l}\text { Kavin Lincecum } \\
\text { v. Collins }\end{array}$ & $\begin{array}{l}958 \text { F. 2d 1271 } \\
\text { (5th Cir. 1992) }\end{array}$ & $12 / 10 / 1992$ & TX \\
\hline $\begin{array}{l}\text { Little, } \\
\text { William }\end{array}$ & $\begin{array}{l}\text { William Little v. } \\
\text { Johnson }\end{array}$ & $\begin{array}{l}\text { 162 F. 3d 855 } \\
\text { (5th Cir. 1998) }\end{array}$ & $06 / 01 / 1999$ & $\mathrm{TX}$ \\
\hline $\begin{array}{l}\text { Lowenfield, } \\
\text { Leslie }\end{array}$ & $\begin{array}{l}\text { Leslie Lowenfield } \\
\text { v. Phelps }\end{array}$ & $\begin{array}{l}817 \text { F. 2d } 285 \\
\text { (5th Cir. 1987) }\end{array}$ & $04 / 13 / 1988$ & LA \\
\hline $\begin{array}{l}\text { Mann, } \\
\text { Fletcher }\end{array}$ & $\begin{array}{l}\text { Fletcher Mann v. } \\
\text { Scott }\end{array}$ & $\begin{array}{l}41 \text { F. 3d } 968 \\
\text { (5th Cir. 1994) }\end{array}$ & $06 / 01 / 1995$ & $\mathrm{TX}$ \\
\hline $\begin{array}{l}\text { Martinez, } \\
\text { David }\end{array}$ & $\begin{array}{l}\text { David Martinez v. } \\
\text { Quarterman }\end{array}$ & $\begin{array}{l}270 \text { Fed. Appx. } \\
277 \text { (5th Cir. } \\
2008) \\
\end{array}$ & $02 / 04 / 2009$ & TX \\
\hline $\begin{array}{l}\text { Martinez, } \\
\text { Raymond }\end{array}$ & $\begin{array}{l}\text { Raymond } \\
\text { Martinez v. Davis }\end{array}$ & $\begin{array}{l}653 \text { Fed. Appx. } \\
308 \text { (5th Cir. } \\
2016 \text { ) }\end{array}$ & $\mathrm{N} / \mathrm{A}$ & TX \\
\hline $\begin{array}{l}\text { Martinez, } \\
\text { Virgil }\end{array}$ & $\begin{array}{l}\text { Virgil Martinez v. } \\
\text { Quarterman }\end{array}$ & $\begin{array}{l}481 \text { F. 3d } 249 \\
\text { (5th Cir. 2007) }\end{array}$ & $01 / 28 / 2009$ & $\mathrm{TX}$ \\
\hline $\begin{array}{l}\text { Masterson, } \\
\text { Richard }\end{array}$ & $\begin{array}{l}\text { Richard } \\
\text { Masterson v. } \\
\text { Stephens } \\
\end{array}$ & $\begin{array}{l}\text { 596 Fed. Appx. } \\
282 \text { (5th Cir. } \\
2015)\end{array}$ & $01 / 20 / 2016$ & $\mathrm{TX}$ \\
\hline $\begin{array}{l}\text { Mathis, } \\
\text { Milton }\end{array}$ & $\begin{array}{l}\text { Milton Mathis v. } \\
\text { Dretke }\end{array}$ & $\begin{array}{l}124 \text { Fed. Appx. } \\
865 \text { (5th Cir. } \\
2005)\end{array}$ & $06 / 21 / 2011$ & $\mathrm{TX}$ \\
\hline $\begin{array}{l}\text { Mattheson, } \\
\text { Howard }\end{array}$ & $\begin{array}{l}\text { Howard } \\
\text { Mattheson v. } \\
\text { King }\end{array}$ & $\begin{array}{l}\text { 751 F. 2d } 1432 \\
\text { (5th Cir. 1985) }\end{array}$ & N/A & LA \\
\hline $\begin{array}{l}\text { Mays, } \\
\text { Randall } \\
\end{array}$ & $\begin{array}{l}\text { Randall Mays v. } \\
\text { Stephens }\end{array}$ & $\begin{array}{l}757 \text { F. 3d } 211 \\
\text { (5th Cir. 2014) }\end{array}$ & $\mathrm{N} / \mathrm{A}$ & TX \\
\hline $\begin{array}{l}\text { McBride, } \\
\text { Michael }\end{array}$ & $\begin{array}{l}\text { Michael McBride } \\
\text { v. Johnson }\end{array}$ & $\begin{array}{l}1997 \text { U.S. App. } \\
\text { LEXIS } 42198 \\
\text { (5th Cir. 1997) }\end{array}$ & $05 / 11 / 2000$ & TX \\
\hline $\begin{array}{l}\text { McCoy, } \\
\text { Stephen }\end{array}$ & $\begin{array}{l}\text { Stephen McCoy } \\
\text { v. Lynaugh }\end{array}$ & $\begin{array}{l}874 \text { F. 2d } 954 \\
\text { (5th Cir. 1989) }\end{array}$ & $05 / 24 / 1989$ & $\mathrm{TX}$ \\
\hline Miniel, Peter & $\begin{array}{l}\text { Peter Miniel v. } \\
\text { Cockrell }\end{array}$ & $\begin{array}{l}339 \text { F. 3d 331 } \\
\text { (5th Cir. 2003) }\end{array}$ & $10 / 06 / 2004$ & $\mathrm{TX}$ \\
\hline Mitchell, & William Mitchell & 641 F. 3d 134 & $03 / 22 / 2012$ & MS \\
\hline
\end{tabular}




\begin{tabular}{|c|c|c|c|c|}
\hline William & v. Epps & (5th Cir. 2011) & & \\
\hline Moody, John & $\begin{array}{l}\text { John Moody v. } \\
\text { Johnson }\end{array}$ & $\begin{array}{l}139 \text { F. 3d } 477 \\
\text { (5th Cir. 1998) }\end{array}$ & $01 / 05 / 1999$ & $\mathrm{TX}$ \\
\hline $\begin{array}{l}\text { Moore, } \\
\text { Bobby }\end{array}$ & $\begin{array}{l}\text { Bobby Moore v. } \\
\text { Johnson }\end{array}$ & $\begin{array}{l}194 \text { F. 3d } 586 \\
\text { (5th Cir. 1999) }\end{array}$ & $\mathrm{N} / \mathrm{A}$ & $\mathrm{TX}$ \\
\hline $\begin{array}{l}\text { Mosley, } \\
\text { Kenneth }\end{array}$ & $\begin{array}{l}\text { Kenneth Mosley } \\
\text { v. Quarterman }\end{array}$ & $\begin{array}{l}306 \text { Fed. Appx. } \\
40 \text { (5th Cir. } \\
2008)\end{array}$ & $01 / 07 / 2010$ & TX \\
\hline $\begin{array}{l}\text { Motley, } \\
\text { Jeffrey }\end{array}$ & $\begin{array}{l}\text { Jeffrey Motley v. } \\
\text { Collins }\end{array}$ & $\begin{array}{l}18 \text { F. 3d } 1223 \\
\text { (5th Cir. 1994) }\end{array}$ & $02 / 07 / 1995$ & TX \\
\hline $\begin{array}{l}\text { Neal, } \\
\text { Howard }\end{array}$ & $\begin{array}{l}\text { Howard Neal v. } \\
\text { Puckett }\end{array}$ & $\begin{array}{l}286 \text { F. 3d } 230 \\
\text { (5th Cir. 2002) }\end{array}$ & $\mathrm{N} / \mathrm{A}$ & MS \\
\hline $\begin{array}{l}\text { Newbury, } \\
\text { Donald } \\
\end{array}$ & $\begin{array}{l}\text { Donald Newbury } \\
\text { v. Stephens }\end{array}$ & $\begin{array}{l}756 \text { F. 3d } 850 \\
\text { (5th Cir. 2014) }\end{array}$ & $02 / 04 / 2015$ & TX \\
\hline Nixon, John & $\begin{array}{l}\text { John Nixon v. } \\
\text { Epps }\end{array}$ & $\begin{array}{l}405 \text { F. 3d } 318 \\
\text { (5th Cir. 2005) }\end{array}$ & $12 / 14 / 2005$ & MS \\
\hline $\begin{array}{l}\text { Nobles, } \\
\text { Jonathan }\end{array}$ & $\begin{array}{l}\text { Jonathan Nobles } \\
\text { v. Johnson }\end{array}$ & $\begin{array}{l}127 \text { F. 3d } 409 \\
\text { (5th Cir. 1997) }\end{array}$ & $10 / 07 / 1998$ & $\mathrm{TX}$ \\
\hline $\begin{array}{l}\text { Norman, } \\
\text { LeJames }\end{array}$ & $\begin{array}{l}\text { LeJames Norman } \\
\text { v. Stephens }\end{array}$ & $\begin{array}{l}817 \text { F. 3d } 226 \\
\text { (5th Cir. 2016) }\end{array}$ & $\mathrm{N} / \mathrm{A}$ & $\mathrm{TX}$ \\
\hline Nuncio, Paul & $\begin{array}{l}\text { Paul Nuncio v. } \\
\text { Johnson }\end{array}$ & $\begin{array}{l}2000 \text { U.S. App. } \\
\text { LEXIS } 41233 \\
\text { (5th Cir. 2000) }\end{array}$ & $06 / 15 / 2000$ & $\mathrm{TX}$ \\
\hline $\begin{array}{l}\text { O'Brien, } \\
\text { Derrick }\end{array}$ & $\begin{array}{l}\text { Derrick O'Brien } \\
\text { v. Dretke }\end{array}$ & $\begin{array}{l}156 \text { Fed. Appx. } \\
724 \text { (5th Cir. } \\
2005 \text { ) }\end{array}$ & $\mathrm{N} / \mathrm{A}$ & $\mathrm{TX}$ \\
\hline Ogan, Craig & $\begin{array}{l}\text { Craig Ogan v. } \\
\text { Cockrell }\end{array}$ & $\begin{array}{l}297 \text { F. 3d } 349 \\
\text { (5th Cir. 2002) }\end{array}$ & $11 / 19 / 2002$ & $\begin{array}{c}\mathrm{TX} \\
\cdot \\
\end{array}$ \\
\hline $\begin{array}{l}\text { Paredes, } \\
\text { Miguel }\end{array}$ & $\begin{array}{l}\text { In re Miguel } \\
\text { Paredes }\end{array}$ & $\begin{array}{l}\text { 587 Fed. Appx. } \\
805 \text { (5th Cir. } \\
\text { 2014) }\end{array}$ & $10 / 28 / 2014$ & $\mathrm{TX}$ \\
\hline $\begin{array}{l}\text { Patterson, } \\
\text { Kelsey }\end{array}$ & $\begin{array}{l}\text { Kelsey Patterson } \\
\text { v. Cockrell }\end{array}$ & $\begin{array}{l}2033 \text { U.S. App. } \\
\text { LEXIS } 28033 \\
\text { (5th Cir. 2003) }\end{array}$ & $05 / 18 / 2004$ & $\mathrm{TX}$ \\
\hline $\begin{array}{l}\text { Perkins, } \\
\text { Reginald }\end{array}$ & $\begin{array}{l}\text { Reginald Perkins } \\
\text { v. Quarterman }\end{array}$ & $\begin{array}{l}254 \text { Fed. Appx. } \\
366 \text { (5th Cir. } \\
2007 \text { ) } \\
\end{array}$ & $01 / 22 / 2009$ & $\mathrm{TX}$ \\
\hline $\begin{array}{l}\text { Perry, } \\
\text { Michael }\end{array}$ & $\begin{array}{l}\text { Michael Perryv. } \\
\text { Quarterman }\end{array}$ & $\begin{array}{l}\text { 314 Fed. Appx. } \\
663 \text { (5th Cir. } \\
2009 \text { ) }\end{array}$ & $07 / 01 / 2010$ & $\mathrm{TX}$ \\
\hline $\begin{array}{l}\text { Prejean, } \\
\text { Dalton }\end{array}$ & $\begin{array}{l}\text { Dalton Prejean v. } \\
\text { Smith }\end{array}$ & $\begin{array}{l}889 \text { F. 2d } 1391 \\
\text { (5th Cir. 1989) }\end{array}$ & $05 / 18 / 1990$ & LA \\
\hline $\begin{array}{l}\text { Raby, } \\
\text { Charles }\end{array}$ & $\begin{array}{l}\text { Charles Raby v. } \\
\text { Dretke }\end{array}$ & $\begin{array}{l}78 \text { Fed. Appx. } \\
324 \text { (5th Cir. } \\
2003 \text { ) }\end{array}$ & $\mathrm{N} / \mathrm{A}$ & $\mathrm{TX}$ \\
\hline $\begin{array}{l}\text { Rayford, } \\
\text { William }\end{array}$ & $\begin{array}{l}\text { William Rayford } \\
\text { v. Stephens }\end{array}$ & $\begin{array}{l}622 \text { Fed. Appx. } \\
315 \text { (5th Cir. } \\
2015 \text { ) }\end{array}$ & $01 / 18 / 2018$ & $\mathrm{TX}$ \\
\hline $\begin{array}{l}\text { Rector, } \\
\text { Charles } \\
\end{array}$ & $\begin{array}{l}\text { Charles Rector v. } \\
\text { Johnson }\end{array}$ & $\begin{array}{l}120 \text { F. 3d 551 } \\
\text { (5th Cir. 1997) }\end{array}$ & $03 / 29 / 1999$ & $\mathrm{TX}$ \\
\hline $\begin{array}{l}\text { Riles, } \\
\text { Raymond }\end{array}$ & $\begin{array}{l}\text { Raymond Riles v. } \\
\text { McCotter }\end{array}$ & $\begin{array}{l}799 \text { F. 2d } 947 \\
\text { (5th Cir. 1986) }\end{array}$ & $\mathrm{N} / \mathrm{A}$ & $\overline{\mathrm{TX}}$ \\
\hline $\begin{array}{l}\text { Riley, } \\
\text { Michael }\end{array}$ & $\begin{array}{l}\text { Michael Riley v. } \\
\text { Dretke }\end{array}$ & $\begin{array}{l}362 \text { F. 3d } 302 \\
\text { (5th Cir. 2004) }\end{array}$ & $05 / 19 / 2005$ & $\mathrm{TX}$ \\
\hline
\end{tabular}




\begin{tabular}{|c|c|c|c|c|}
\hline $\begin{array}{l}\text { Robertson, } \\
\text { Brian }\end{array}$ & $\begin{array}{l}\text { Brian Robertson } \\
\text { v. Johnson }\end{array}$ & $\begin{array}{l}\text { 2000 U.S. App. } \\
\text { LEXIS } 40417 \\
\text { (5th Gir. 2000) }\end{array}$ & $08 / 09 / 2000$ & TX \\
\hline $\begin{array}{l}\text { Roberts, } \\
\text { Douglas }\end{array}$ & $\begin{array}{l}\text { Douglas Roberts } \\
\text { v. Dretke }\end{array}$ & $\begin{array}{l}381 \text { F. 3d 491 } \\
\text { (5th Cir. 2004) }\end{array}$ & $04 / 20 / 2005$ & TX \\
\hline $\begin{array}{l}\text { Robinson, } \\
\text { Julius }\end{array}$ & $\begin{array}{l}\text { Julius Robinson } \\
\text { v. United States }\end{array}$ & $\begin{array}{l}2010 \text { U.S. App. } \\
\text { LEXIS } 11675 \\
\text { (5th Cir. } 2010 \text { ) }\end{array}$ & $\mathrm{N} / \mathrm{A}$ & $\mathrm{TX}$ \\
\hline $\begin{array}{l}\text { Robison, } \\
\text { Larry }\end{array}$ & $\begin{array}{l}\text { Larry Robison v. } \\
\text { Johnson }\end{array}$ & $\begin{array}{l}151 \text { F. 3d } 256 \\
\text { (5th Cir. 1998) }\end{array}$ & $01 / 21 / 2000$ & TX \\
\hline $\begin{array}{l}\text { Rockwell, } \\
\text { Kwame }\end{array}$ & $\begin{array}{l}\text { Kwame Rockwell } \\
\text { v. Davis }\end{array}$ & $\begin{array}{l}853 \text { F. 3d } 758 \\
\text { (5th Cir. 2017) }\end{array}$ & $\mathrm{N} / \mathrm{A}$ & TX \\
\hline $\begin{array}{l}\text { Rodriguez, } \\
\text { Rosendo }\end{array}$ & $\begin{array}{l}\text { Rosendo } \\
\text { Rodriguez v. } \\
\text { Davis } \\
\end{array}$ & $\begin{array}{l}693 \text { Fed. Appx. } \\
276 \text { (5th Cir. } \\
2017 \text { ) }\end{array}$ & $03 / 27 / 2018$ & TX \\
\hline $\begin{array}{l}\text { Romero, } \\
\text { Jesus }\end{array}$ & $\begin{array}{l}\text { Jesus Romero v. } \\
\text { Lynaugh }\end{array}$ & $\begin{array}{l}884 \text { F. 2d } 871 \\
\text { (5th Cir. 1989) }\end{array}$ & $05 / 20 / 1992$ & $\mathrm{TX}$ \\
\hline $\begin{array}{l}\text { Santellan, } \\
\text { Jose }\end{array}$ & $\begin{array}{l}\text { Jose Santellan v. } \\
\text { Cockrell }\end{array}$ & $\begin{array}{l}271 \text { F. 3d } 190 \\
\text { (5th Cir. 190) }\end{array}$ & $04 / 10 / 2002$ & $\mathrm{TX}$ \\
\hline $\begin{array}{l}\text { Sattiewhite, } \\
\text { Vernon }\end{array}$ & $\begin{array}{l}\text { Vernon } \\
\text { Sattiewhite v. } \\
\text { Scott } \\
\end{array}$ & $\begin{array}{l}1995 \text { U.S. App. } \\
\text { LEXIS } 41815 \\
\text { (5th Cir. 1995) }\end{array}$ & $08 / 15 / 1995$ & $\mathrm{TX}$ \\
\hline $\begin{array}{l}\text { Sawyer, } \\
\text { Robert }\end{array}$ & $\begin{array}{l}\text { Robert Sawyer v. } \\
\text { Butler }\end{array}$ & $\begin{array}{l}848 \text { F. 2d } 582 \\
\text { (5th Cir. 1988) }\end{array}$ & $03 / 05 / 1993$ & LA \\
\hline $\begin{array}{l}\text { Segundo, } \\
\text { Juan }\end{array}$ & $\begin{array}{l}\text { Juan Segundo v. } \\
\text { Davis }\end{array}$ & $\begin{array}{l}831 \text { F. 3d } 345 \\
\text { (5th Cir. 2016) }\end{array}$ & $\mathrm{N} / \mathrm{A}$ & $\mathrm{TX}$ \\
\hline Sells, Tommy & $\begin{array}{l}\text { Tommy Sells v. } \\
\text { Stephens }\end{array}$ & $\begin{array}{l}536 \text { Fed. Appx. } \\
483 \text { (5th Cir. } \\
2013)\end{array}$ & $04 / 03 / 2014$ & TX \\
\hline Selvage, John & $\begin{array}{l}\text { John Selvage v. } \\
\text { Lynaugh }\end{array}$ & $\begin{array}{l}842 \text { F. 2d } 89 \\
\text { (5th Cir. 1988) }\end{array}$ & $\mathrm{N} / \mathrm{A}$ & TX \\
\hline $\begin{array}{l}\text { Sepulvado, } \\
\text { Christopher }\end{array}$ & $\begin{array}{l}\text { Christopher } \\
\text { Sepulvado v. Cain }\end{array}$ & $\begin{array}{l}2003 \text { U.S. App. } \\
\text { LEXIS } 28732 \\
\text { (5th Cir. 2003) }\end{array}$ & $\mathrm{N} / \mathrm{A}$ & $\mathrm{TX}$ \\
\hline $\begin{array}{l}\text { Shore, } \\
\text { Anthony }\end{array}$ & $\begin{array}{l}\text { Anthony Shore v. } \\
\text { Davis }\end{array}$ & $\begin{array}{l}845 \text { F. 3d } 627 \\
\text { (5th Cir. 2017) }\end{array}$ & $01 / 18 / 2018$ & $\mathrm{TX}$ \\
\hline $\begin{array}{l}\text { Sigala, } \\
\text { Michael }\end{array}$ & $\begin{array}{l}\text { Michael Sigala v. } \\
\text { Quarterman }\end{array}$ & $\begin{array}{l}338 \text { Fed. Appx. } \\
388 \text { (5th Cir. } \\
2009 \text { ) }\end{array}$ & $03 / 02 / 2010$ & $\mathrm{TX}$ \\
\hline $\begin{array}{l}\text { Simmons, } \\
\text { Gary }\end{array}$ & $\begin{array}{l}\text { Gary Simmons v. } \\
\text { Epps }\end{array}$ & $\begin{array}{l}381 \text { Fed. Appx. } \\
339 \text { (5th Cir. } \\
2010 \text { ) }\end{array}$ & $06 / 20 / 2012$ & MS \\
\hline Slater, Paul & $\begin{array}{l}\text { Paul Slater v. } \\
\text { Davis }\end{array}$ & $\begin{array}{l}2018 \text { U.S. App. } \\
\text { LEXIS } 901 \\
\text { (5th Cir. } 2018 \text { ) }\end{array}$ & $\mathrm{N} / \mathrm{A}$ & TX \\
\hline $\begin{array}{l}\text { Smith, } \\
\text { Charles }\end{array}$ & $\begin{array}{l}\text { Charles Smith v. } \\
\text { Quarterman }\end{array}$ & $\begin{array}{l}471 \text { F. 3d } 565 \\
\text { (5th Cir. 2006) }\end{array}$ & $05 / 16 / 2017$ & TX \\
\hline Smith, Willie & $\begin{array}{l}\text { Willie Smith v. } \\
\text { Black }\end{array}$ & $\begin{array}{l}904 \text { F. } 2 \text { d } 950 \\
\text { (5th Cir. 1990) }\end{array}$ & $\mathrm{N} / \mathrm{A}$ & MS \\
\hline Sosa, Pedro & $\begin{array}{l}\text { Pedro Sosa v. } \\
\text { Dretke }\end{array}$ & $\begin{array}{l}133 \text { Fed. Appx. } \\
114 \text { (5th Cir. } \\
2005 \text { ) }\end{array}$ & $\mathrm{N} / \mathrm{A}$ & $\mathrm{TX}$ \\
\hline Stoker, David & $\begin{array}{l}\text { David Stoker v. } \\
\text { Scott }\end{array}$ & $\begin{array}{l}1996 \text { U.S. App. } \\
\text { LEXIS } 42604\end{array}$ & $06 / 16 / 1997$ & $\mathrm{TX}$ \\
\hline
\end{tabular}




\begin{tabular}{|c|c|c|c|c|}
\hline & & (5th Cir. 1996) & & \\
\hline Storey, Paul & $\begin{array}{l}\text { Paul Storey v. } \\
\text { Stephens }\end{array}$ & $\begin{array}{l}606 \text { Fed Appx. } \\
192 \text { (5th Cir. } \\
2015 \text { ) }\end{array}$ & $\mathrm{N} / \mathrm{A}$ & TX \\
\hline $\begin{array}{l}\text { Tamayo, } \\
\text { Edgar }\end{array}$ & $\begin{array}{l}\text { Edgar Tamayo v. } \\
\text { Thaler }\end{array}$ & $\begin{array}{l}2011 \text { U.S. App. } \\
\text { LEXIS 26665 } \\
\text { (5th Cir. 2011) }\end{array}$ & $01 / 22 / 2014$ & $\mathrm{TX}$ \\
\hline $\begin{array}{l}\text { Thompson, } \\
\text { John }\end{array}$ & $\begin{array}{l}\text { John Thompson } \\
\text { v. Cain }\end{array}$ & $\begin{array}{l}61 \text { F. 3d } 802 \\
\text { (5th Gir. 1998) }\end{array}$ & $07 / 08 / 1987$ & $\mathrm{TX}$ \\
\hline $\begin{array}{l}\text { Thompson, } \\
\text { Robert }\end{array}$ & $\begin{array}{l}\text { Robert } \\
\text { Thompson v. } \\
\text { Quarterman }\end{array}$ & $\begin{array}{l}292 \text { Fed. Appx. } \\
277 \text { (5th Cir. } \\
2008 \text { ) }\end{array}$ & $11 / 19 / 2009$ & TX \\
\hline $\begin{array}{l}\text { Titsworth, } \\
\text { Timothy }\end{array}$ & $\begin{array}{l}\text { Timothy } \\
\text { Titsworth v. } \\
\text { Dretke } \\
\end{array}$ & $\begin{array}{l}\text { 401 F. 3d 301 } \\
\text { (5th Gir. 2005) }\end{array}$ & $06 / 06 / 2006$ & TX \\
\hline $\begin{array}{l}\text { Trottie, } \\
\text { Willie } \\
\end{array}$ & $\begin{array}{l}\text { Willie Trottie v. } \\
\text { Stephens }\end{array}$ & $\begin{array}{l}720 \text { F. 3d } 231 \\
\text { (5th Cir. 2013) }\end{array}$ & $09 / 10 / 2014$ & $\mathrm{TX}$ \\
\hline $\begin{array}{l}\text { Tucker, } \\
\text { Karla }\end{array}$ & $\begin{array}{l}\text { Karla Tucker v. } \\
\text { Johnson }\end{array}$ & $\begin{array}{l}1997 \text { U.S. App. } \\
\text { LEXIS } 16312 \\
\text { (5th Cir. 1997) }\end{array}$ & $02 / 03 / 1998$ & $\mathrm{TX}$ \\
\hline $\begin{array}{l}\text { Tucker, } \\
\text { Jeffrey }\end{array}$ & $\begin{array}{l}\text { Jeffrey Tucker v. } \\
\text { Johnson }\end{array}$ & $\begin{array}{l}242 \text { F. } 3 d 617 \\
\text { (5th Cir. 2001) }\end{array}$ & $11 / 14 / 2001$ & TX \\
\hline $\begin{array}{l}\text { Turner, } \\
\text { Edwin }\end{array}$ & $\begin{array}{l}\text { Edwin Turner v. } \\
\text { Epps }\end{array}$ & $\begin{array}{l}412 \text { Fed. Appx. } \\
696 \text { (5th Cir. } \\
2011 \text { ) }\end{array}$ & $02 / 08 / 2012$ & MS \\
\hline $\begin{array}{l}\text { Van Alstyne, } \\
\text { Gregory }\end{array}$ & $\begin{array}{l}\text { Gregory Van } \\
\text { Alstyne v. } \\
\text { Cockrell }\end{array}$ & $\begin{array}{l}\text { 2002 U.S. App. } \\
\text { LEXIS } 29069 \\
\text { (5th Cir.2002) }\end{array}$ & $\mathrm{N} / \mathrm{A}$ & TX \\
\hline $\begin{array}{l}\text { Valle, } \\
\text { Yosvannis }\end{array}$ & $\begin{array}{l}\text { Yosvannis Valle v. } \\
\text { Quarterman }\end{array}$ & $\begin{array}{l}\text { 2008 U.S. App. } \\
\text { LEXIS } 22165 \\
\text { (5th Cir. 2008) } \\
\end{array}$ & $\mathrm{N} / \mathrm{A}$ & TX \\
\hline $\begin{array}{l}\text { Vasquez, } \\
\text { Richard }\end{array}$ & $\begin{array}{l}\text { Richard Vasquez } \\
\text { v. Thaler }\end{array}$ & $\begin{array}{l}389 \text { Fed. Appx. } \\
419 \text { (5th Cir. } \\
2010)\end{array}$ & N/A & $\mathrm{TX}$ \\
\hline Villegas, Jose & $\begin{array}{l}\text { Jose Villegas v. } \\
\text { Quarterman }\end{array}$ & $\begin{array}{l}274 \text { Fed. Appx. } \\
378 \text { (5th Cir. } \\
2008 \text { ) }\end{array}$ & $04 / 16 / 2014$ & $\mathrm{TX}$ \\
\hline Ward, Adam & $\begin{array}{l}\text { Adam Ward v. } \\
\text { Stephens }\end{array}$ & $\begin{array}{l}777 \text { F. 3d } 250 \\
\text { (5th Cir. 2015) }\end{array}$ & $03 / 22 / 2016$ & $\mathrm{TX}$ \\
\hline $\begin{array}{l}\text { Washington, } \\
\text { Terry }\end{array}$ & $\begin{array}{l}\text { Terry } \\
\text { Washington v. } \\
\text { Johnson }\end{array}$ & $\begin{array}{l}90 \text { F. 3d } 945 \\
\text { (5th Cir. 1996) }\end{array}$ & $05 / 06 / 1997$ & TX \\
\hline $\begin{array}{l}\text { Webster, } \\
\text { Bruce }\end{array}$ & $\begin{array}{l}\text { Bruce Webster v. } \\
\text { United States }\end{array}$ & $\begin{array}{l}392 \text { F. 3d } 787 \\
\text { (5th Cir. 2004) }\end{array}$ & $\mathrm{N} / \mathrm{A}$ & $\mathrm{N} / \mathrm{A}$ \\
\hline $\begin{array}{l}\text { Wesbrook, } \\
\text { Coy }\end{array}$ & $\begin{array}{l}\text { Coy Wesbrook v. } \\
\text { Thaler }\end{array}$ & $\begin{array}{l}585 \text { F. 3d } 245 \\
\text { (5th Cir. 2009) }\end{array}$ & $03 / 09 / 2016$ & $\mathrm{TX}$ \\
\hline West, Robert & $\begin{array}{l}\text { Robert West v. } \\
\text { Johnson }\end{array}$ & $\begin{array}{l}\text { 92 F. 3d } 1385 \\
\text { (5th Cir. 1996) }\end{array}$ & $07 / 29 / 1997$ & TX \\
\hline Wheat, John & $\begin{array}{l}\text { John Wheat v. } \\
\text { Johnson }\end{array}$ & $\begin{array}{l}238 \text { F. 3d } 357 \\
\text { (5th Cir. 2001) }\end{array}$ & $06 / 13 / 2001$ & TX \\
\hline $\begin{array}{l}\text { Whitaker, } \\
\text { George }\end{array}$ & $\begin{array}{l}\text { George Whitaker } \\
\text { v. Quarterman }\end{array}$ & $\begin{array}{l}200 \text { Fed. Appx. } \\
351 \text { ( } 5 \text { th Cir. } \\
2006 \text { ) }\end{array}$ & $11 / 12 / 2008$ & $\mathrm{TX}$ \\
\hline
\end{tabular}




\begin{tabular}{|c|c|c|c|c|}
\hline $\begin{array}{l}\text { White, } \\
\text { Robert }\end{array}$ & $\begin{array}{l}\text { Robert White v. } \\
\text { Johnson }\end{array}$ & $\begin{array}{l}153 \text { F. 3d } 197 \\
\text { (5th Cir. 1998) }\end{array}$ & $03 / 30 / 1999$ & TX \\
\hline $\begin{array}{l}\text { Wiley, } \\
\text { William }\end{array}$ & $\begin{array}{l}\text { William Wiley v. } \\
\text { Puckett }\end{array}$ & $\begin{array}{l}969 \text { F. } 2 d 86 \\
\text { (5th Cir. 1992) }\end{array}$ & $\mathrm{N} / \mathrm{A}$ & MS \\
\hline $\begin{array}{l}\text { Wilkerson, } \\
\text { Richard }\end{array}$ & $\begin{array}{l}\text { Richard } \\
\text { Wilkerson v. } \\
\text { Collins }\end{array}$ & $\begin{array}{l}950 \text { F. 2d } 1054 \\
\text { (5th Cir. 1992) }\end{array}$ & $08 / 31 / 1993$ & $\mathrm{TX}$ \\
\hline $\begin{array}{l}\text { Wilkins, } \\
\text { Christopher }\end{array}$ & $\begin{array}{l}\text { Christopher } \\
\text { Wilkins v. } \\
\text { Stephens }\end{array}$ & $\begin{array}{l}560 \text { Fed. Appx. } \\
299 \text { (5th Cir. } \\
2014 \text { ) }\end{array}$ & $01 / 11 / 2017$ & $\mathrm{TX}$ \\
\hline $\begin{array}{l}\text { Williams, } \\
\text { Clifton }\end{array}$ & $\begin{array}{l}\text { Clifton Williams } \\
\text { v. Stephens }\end{array}$ & $\begin{array}{l}761 \text { F. 3D 561 } \\
\text { (5th Cir. 2014) }\end{array}$ & $\mathrm{N} / \mathrm{A}$ & TX \\
\hline $\begin{array}{l}\text { Williams, } \\
\text { Dobie }\end{array}$ & $\begin{array}{l}\text { Dobie Williams v. } \\
\text { Cain }\end{array}$ & $\begin{array}{l}125 \text { F. 3d } 269 \\
\text { (5th Cir. 1997) }\end{array}$ & $01 / 08 / 1999$ & $\mathrm{LA}$ \\
\hline $\begin{array}{l}\text { Williams, } \\
\text { Walter }\end{array}$ & $\begin{array}{l}\text { Walter Williams } \\
\text { v. Collins }\end{array}$ & $\begin{array}{l}16 \text { F. 3d } 626 \\
\text { (5th Cir. 1994) }\end{array}$ & $10 / 05 / 1994$ & TX \\
\hline $\begin{array}{l}\text { Willie, } \\
\text { Robert }\end{array}$ & $\begin{array}{l}\text { Robert Willie v. } \\
\text { Maggio }\end{array}$ & $\begin{array}{l}737 \text { F. 2d } 1372 \\
\text { (5th Cir. 1984) }\end{array}$ & $12 / 28 / 1984$ & LAA \\
\hline $\begin{array}{l}\text { Woodard, } \\
\text { Robert }\end{array}$ & $\begin{array}{l}\text { Robert Woodard } \\
\text { v. Thaler }\end{array}$ & $\begin{array}{l}\text { 414 Fed. Appx. } \\
675 \text { (5th Cir. } \\
\text { 2011) }\end{array}$ & $\mathrm{N} / \mathrm{A}$ & TX \\
\hline Woods, Billy & $\begin{array}{l}\text { Billy Woods v. } \\
\text { Johnson }\end{array}$ & $\begin{array}{l}75 \text { F. 3d } 1017 \\
\text { (5th Cir. 1996) }\end{array}$ & $04 / 14 / 1997$ & $\mathrm{TX}$ \\
\hline $\begin{array}{l}\text { Woods, } \\
\text { Steven }\end{array}$ & $\begin{array}{l}\text { Steven Woods v. } \\
\text { Thaler }\end{array}$ & $\begin{array}{l}399 \text { Fed. Appx. } \\
884 \text { (5th Cir. } \\
2010)\end{array}$ & $09 / 13 / 2011$ & TX \\
\hline $\begin{array}{l}\text { Yowell, } \\
\text { Michael }\end{array}$ & $\begin{array}{l}\text { Michael Yowell v. } \\
\text { Thaler }\end{array}$ & $\begin{array}{l}442 \text { Fed. Appx. } \\
100 \text { (5th Cir. } \\
2011 \text { ) }\end{array}$ & $10 / 09 / 2013$ & TX \\
\hline
\end{tabular}

All information from deathpenaltyinfo.org. 


\section{APPENDIX B}

In the Appendix, we share what we have been able to learn (from Westlaw, Internet searches and correspondence with most of the defendants' appellate lawyers) happened after the decision in the Fifth Circuit case that relied on Strickland to order remands, to vacate convictions, or to issue Certificates of Appealability.

\section{Kevin Zimmerman:}

In Zimmerman $v$. Cockrell, ${ }^{334}$ the Fifth Circuit granted a COA. ${ }^{335}$ Subsequently, that court affirmed the decision below (finding his Strickland claims did not merit relief), ${ }^{336}$ and Zimmerman's certiorari petition was denied. ${ }^{337}$ Zimmerman was executed in $2004 .^{338}$

\section{Alvin Scott Loyd:}

In Loyd $v$. Whitley, ${ }^{399}$ the Fifth Circuit reversed and remanded Loyd's conviction and sentence, finding that trial counsel's failure to pursue independent psychological analysis of defendant was not professionally reasonable. ${ }^{340}$ After the Supreme Court denied the state's petition for certiorari, ${ }^{341}$ Loyd

334. Zimmerman v. Cockrell, No. 01-40591, 2002 WL 32833097 (5th Cir. 2002).

335. In earlier proceedings, the Supreme Court had remanded this case to the Texas Court of Criminal Appeals in light of its decision in Johnson v. Texas, 509 U.S. 350 (1993), on the question of the extent to which jury instructions on the question of future dangerousness took into account the defendant's youth. See Zimmerman v. Texas, 510 U.S. 938 (1993)

336. See Zimmerman v. Cockrell, 69 F. App'x 658, 2003 WL 21356018, *12 (5th Cir. 2003).

337. Zimmerman v. Dretke, 540 U.S. 1076 (2003).

338. See Kevin Zimmerman, THE MARSHALL. PROJECT, https://www.themarshall project.org/next-to-die/tx/0k47ocsq (last visited Jan. 8, 2020).

339. Loyd v. Whitley, 977 F.2d 149 (5th Cir. 1992).

340. One of Loyd's trial counsel-Gordon Hackman-was subsequently suspended from the practice of law in Louisiana for two and a half years. See In re Gordon L. Hackman, 02-B1692 (La. 12/4/02); 833 So. 2 d 916.

341. Whitley v. Loyd, 508 U.S. 911 (1993). In a subsequent matter related to the case (not related to the substance of this Article), the Fifth Circuit ruled on a question of attorneys' fees under the Criminal Justice Act and the Federal Anti-Drug Abuse Act. See 18 U.S.C. \$ 3006A; 21 U.S.C. \$ 848; Loyd v. Whitley, 20 F.3d 1171 (5th Cir. 1994). 
was later retried; ${ }^{342}$ the jury returned a unanimous verdict for life imprisonment. ${ }^{343}$

\section{Bobby James Moore:}

In Moore $v$. Johnson, ${ }^{344}$ the Fifth Circuit found that trial counsel's deficient performance prejudiced the outcome of the punishment phase, and it remanded for further proceedings. The death penalty was reinstated in state court. ${ }^{345}$

In subsequent proceedings, the Supreme Court vacated Moore's conviction, ${ }^{346}$ on the grounds that the factors the Texas court had relied upon in evaluating claims brought under Atkins $v$. Virginia ${ }^{317}$ were based on superseded medical standards that create an unacceptable risk that a person with intellectual disabilities will be executed in violation of the Eighth Amendment On remand, relief was denied ${ }^{348}$; subsequently, the Supreme Court again granted certiorari and once more vacated Moore's conviction. ${ }^{349}$

\section{Walter J. Koon:}

In Koon $v$. Cain, ${ }^{350}$ the Fifth Circuit affirmed a district court decision that defendant's trial counsel was ineffective. ${ }^{351}$ After the Supreme Court denied the state's petition for certiorari, ${ }^{352}$ Koon was subsequently sentenced to life without parole. ${ }^{353}$

\footnotetext{
342. See State v. Loyd, 966-KK-1805 (La. 2/13/97); 689 So. 2d 1321.

343. Email from John Getsinger, Esq., Counsel to Alvin Loyd, to authors (Jan. 20, 2019) (on file with author).

344. Moore v. Johnson, 194 F.3d 586 (5th Cir. 1999).

345. See Moore v. State, No. 74-059, 2004 WL 231323 (Tex. Crim. App. 2004), cerl. denied, 543 U.S. 931 (2004).

346. Moore v. Texas, 137 S. Ct. 1039 (2017).

347. Atkins v. Virginia, 536 U.S. 304 (2002).

348. Ex Parte Moore, 548 S.W.3d 552 (Tex. Crim. App. 2018).

349. Moore v. Texas, 139 S. Ct. 666 (2019); see supra text accompanying note 271. The Teas Court of Criminal Appeals subsequently resentenced Moore to a term of life imprisonment. See Ex parte Moore, 587 S.W. 3d 787 (Tex. Ct. Crim. App. 2019).).

350. Koon v. Cain, 277 F. App'x 381, 2008 WL 1924217 (5th Cir. 2008).

351. See John Floyd \& Billy Sinclair, Ineffertive Assistance of Conensel in Capital Cases, JOHN T. FLOYD L. FIRM (Dec. 5, 2008), https://www.johntfloyd.com/ineffective-assistance-of-counselin-capital-cases/ (discussing in depth the ineffective work done by Koon's trial counsel). 352. Cain v. Koon, 555 U.S. 1010 (2008).

353. E.g., John Pope, Sam Dallon, Sex-Decade Lauyer Who Fonght Death Penally, Defended Poor People, Dies at 90, NOLA.cOM (Sept. 6, 2017), https://www.nola.com/news/crime police/article_e2480b59-86be-5cba-b9ff-a3697f902ef2.html.
} 


\section{Anthony Leroy Pierce:}

In Pierce $v$. Thaler, ${ }^{354}$ the Fifth Circuit ruled that the defendant was entitled to a COA on his ineffectiveness of counsel claim. ${ }^{355}$ Subsequently, however, the same court ruled that the defendant was not entitled to an evidentiary hearing in the federal district court on his claim under Atkins, that his intellectual disability estopped the state from executing him. ${ }^{356}$

Subsequently, after thirty-five years, the defendant was taken off death row and was resentenced to life without parole. ${ }^{357}$

\section{Gaylon Walbey Jr.:}

In Walbey v. Quarterman, ${ }^{358}$ the Fifth Circuit held that the defendant had been denied effective assistance as a result of trial counsel's deficient investigation of a potential mitigation defense. Although the chief county District Attorney announced at this time that he was going to seek the death penalty again in a new trial, his successor in office chose to accept, instead, a plea to a life sentence. ${ }^{359}$

\section{Carlos Trevino:}

In Trevino $v$. Davis, ${ }^{360}$ the Fifth Circuit granted a COA on the issue of ineffectiveness of counsel. ${ }^{361}$ In subsequent proceedings, however, the Circuit ruled (with one dissent) that trial counsel's alleged failure to adequately investigate and

354. Pierce v. Thaler, 355 F. App'x 784, 2009 WL 4572839 (5th Cir. 2009).

355. Pierce's trial lawyer was subsequently suspended. See In re Ronald G. Mock, BD. Disciplinary APP., TEX. (Dec. 8, 2004), http://txboda.org/cases/re-ronald-g-mock.

356. Pierce v. Thaler, 604 F.3d 197 (5th Cir. 2010).

357. E.g., Allan Turner, DA's Office Plans to Not Seek Execution of Man on Death Row Since 1978, CHRON (Aug. 30, 2012, 3:00 AM), https://www.chron.com/news/houstontexas/article/DA-s-office-plans-to-not-seek-execution-of-man-on-3825169.php. See also email from David Dow Esq., Pierce's appellate counsel, to authors of this Article (Jan. 20, 2019).

358. Walbey v. Quarterman, 309 F. App'x 795, 2009 WL 113778 (5th Cir. 2009).

359. See Leigh Jones, supra note 191; see also Harvey Rice, Death Roul Inmate Gets a Chance to Avoid Execulion, CHRon (Jan. 19, 2009), https://www.chron.com/neighborhood/baytownnews/article/Death-row-inmate-gets-a-chance-to-avoid-execution-1537243.php (providing further information about the Fifth Circuit's decision).

360. Trevino v. Davis, 829 F.3d 328 (5th Cir. 2016).

361. Id. at 356 . This decision followed a 5-4 remand from the U.S. Supreme Court ruling that further proceedings were required to determine whether petitioner's attorney in his first state collateral proceeding was ineffective, and whether the ineffective assistance of trial counsel claim was substantial. See Trevino v. Thaler, 569 U.S. 413 (2013). 
present certain mitigating evidence at sentencing did not prejudice petitioner, and thus was not ineffective assistance. ${ }^{362}$

\section{Victor Hugo Saldaño:}

In Saldaño v. Davis, ${ }^{363}$ the Fifth Circuit ruled that there was a question as to whether trial counsel behaved deficiently in failing to request a competency hearing, granting in part the defendant's application for a COA. ${ }^{361}$ In subsequent proceedings, however, the Fifth Circuit affirmed the district court's denial of habeas corpus relief, finding that the defendant "has failed to offer clear and convincing evidence to rebut the state habeas court's factual determination that there was insufficient evidence to raise a bona fide doubt as to competency." 365

\section{Andre Lewis:}

In Lewis v. Johnson, ${ }^{366}$ the Fifth Circuit remanded the case to the district court for a full evidentiary hearing on the defendant's claims of inadequacy of counsel. Subsequently, in Lewis v. Cockrell, ${ }^{367}$ the district court found that, "even if the 'cause' prong were satisfied, Petitioner has failed to prove

362. See Trevino v. Davis, 861 F. 3d 545, 550-51 (5th Cir. 2017), cert. denied, 138 S. Ct. 1793 (2018). For Trevino's thoughts, see Carlos Trevino \#999235, DEATHRow-USA, http://deathrow-usa.com/carlos_trevino.htm (last visited Nov. 1, 2019).

363. Saldaño v. Davis, 701 Fed. App'x 302 (5th Cir. 2017).

364. Id. at 316. Earlier, the Supreme Court had remanded this case "for further consideration in light of the confession of error by the Solicitor General of Texas." Saldaño v. Texas, 530 U.S. 1212, 1212 (2000). Apparently, that "confession of error" dealt with the question of " $[w]$ hether a defendant's race or ethnic background may ever be used as an aggravating circumstance in the punishment phase of a capital murder trial in which the State seeks the death penalty." Saldaño v. State, 70 S.W.3d 873, 875 (Tex. Crim. App. 2002). The court concluded that "the State's confession of error in the Supreme Court is contrary to our state's procedural law for presenting a claim on appeal, as well as the Supreme Court's enforcement of such procedural law when it is presented with equal-protection claims." Id. at 891 .

365. Saldaño v. Davis, 759 F. App'x 276, 279 (5th Cir 2019), cert. denied 2019 WL 6107808 (2019). Saldaño is the only Argentinian citizen on death row. See Gerald O'Connell, Today Pope Francis Met with the Mother of the Only Argentinian on Death Row in the Uniled States, AM. MAG. (June 11, 2016), https://www.americamagazine.org/content/dispatches/pope-francismeets-mother-only-argentinian-death-row-united-states; Jordan S. Rubin, Angentina Backs Texas Death Rav Prisoner at U.S. Supreme Cont, BLOOMBERG LAW (Oct. 23, 2019). On his mother's conversations with the Pope about this case, see Associated Press, Argenitinian Mom Hopes Pope Can Help Get Son Out of Texas Death Row, NBC News (Aug. 27, 2015, 10:34 AM), https://www.nbcnews.com/news/latino/argentinian-mom-hopes-pope-can-help-get-son-outtexas-n416821.

366. Lewis v. Johnson, No. 96-10616, 2000 WL 35549205 (5th Cir. 2000).

367. Lewis v. Cockrell, No. 3-93-329-G, 2002 WL 1398554 (N.D. Tex. 2002). 
'prejudice' as set out in Strickland." ${ }^{368}$ This decision was then reversed by the Fifth Circuit, finding that counsel's performance in failing to adduce evidence of petitioner's abusive childhood at penalty phase was deficient, thus causing prejudice. $^{369}$

According to a press account, Lewis was subsequently removed from death row and was, at the time of the article, serving a life sentence in a different Texas state prison. ${ }^{370}$ with the possibility of parole. ${ }^{371}$

\section{David Earl Wilson:}

In Wilson v. Butler, ${ }^{372}$ the Fifth Circuit ruled that trial counsel had performed deficiently regarding the investigation into Wilson's mental health and the subsequent presentation of this evidence at the penalty phase. His entitlement to a rehearing was affirmed by the Circuit in a subsequent opinion. ${ }^{373}$ Subsequently, Wilson was finally granted a new trial and, in a plea bargain with the state, pled guilty to life in prison rather than going to trial once more. ${ }^{374}$

\section{Carl Lockett:}

In Lockett $v$. Anderson, ${ }^{375}$ the Fifth Circuit ruled that trial counsel was ineffective in failing to conduct adequate investigation into available mitigating evidence. After remand, the defendant was sentenced to life without parole. ${ }^{376}$

368. Id. at *12.

369. See Lewis v. Dretke, 355 F.3d 364, 369-70 (5th Cir. 2003).

370. See Robert Wilonsky, Life After Death, Dall. ObSERver (Dec. 16, 2004), https://www.dallasobserver.com/news/life-after-death-6382994.

371. See email from Richard Ellis, Esq., Lewis's appellate counsel, to authors (Jan. 21, 2019) (on file with authors).

372. Wilson v. Butler, 813 F.2d 664 (5th Cir. 1987).

373. See Wilson v. Butler 825 F.2d 879 (5th Cir. 1987), cert. denied, 484 U.S. 1079 (1988).

374. See email from William Quigley, Esq., Wilson's appellate counsel, to authors (Jan. 19, 2019) (on file with authors). For more on Wilson and the litigation, see Wilson v. Zimmerman, No. 08-3507, 2008 WL 2699740 (E.D. La. 2008)

375. Lockett v. Anderson, 230 F.3d 695 (5th Cir. 2000).

376. See email from Jeffrey Friesen, Esq., Lockett's appellate counsel, to authors (Jan. 19, 2019) (on file with authors). 


\section{Edward Lee Busby:}

In Busby v. Davis, ${ }^{377}$ the Fifth Circuit granted a COA on the questions of whether the defendant received ineffective assistance of direct appeal counsel, and whether trial counsel was ineffective by failing to conduct an adequate sentencing investigation or to present an adequate mitigation case during the penalty phase of trial. On rehearing, the Fifth Circuit held that Busby did not establish ineffectiveness by counsel, and again affirmed the conviction. ${ }^{378}$ According to Busby's appellate counsel, defendant's petition for rehearing en banc is pending. ${ }^{379}$

\section{Larry Jones}

In Jones $v$. Thigpen, ${ }^{380}$ the Fifth Circuit affirmed its earlier decision that Jones had been denied ineffective assistance of counsel on the ground of ineffectiveness of counsel at the sentencing phase of the case, where counsel failed to present proof at sentencing phase of age and mental disability of defendant, who was mentally disabled, seventeen years old at time of crime, and there had been no proof that he had had any intent or role in homicide. ${ }^{381}$ After the Supreme Court's denials of certiorari, ${ }^{382}$ there is no more information to be found about the case. ${ }^{383}$

377. Busby v. Davis, 677 F. App'x 884 (5th Cir. 2017).

378. Busby v. Davis, 892 F.3d 735, 762 (5th Cir. 2018).

379. See email from David Dow, Esq., Busby's current appellate counsel, to authors (Jan. 20, 2019) (on file with authors).

380. Jones v. Thigpen, 788 F. 2d 1101 (5th Gir. 1986).

381. Id . at 1103 . The Fifth Gircuit's earlier decision, Jones v. Thigpen, 741 F.2d 805 (5th Cir. 1984), had been vacated by the Supreme Court in Thigpen v. Jones, 475 U.S. 1003 (1986), in light of that Court's intervening decision in Cabana v. Bullock, 474 U.S. 376 (1986), on the question of death-eligibility in cases involving whether the defendant had intended to commit homicide.

382. See Thigpen v. Jones, 479 U.S. 1087 (1987).

383. Emails to counsel went unanswered. 